1976

\title{
The Archaeology and History of Alamo Plaza
}

Anne A. Fox

Feris A. Bass

Thomas R. Hester

Center for Archaeological Research

Follow this and additional works at: https://scholarworks.sfasu.edu/ita

Part of the American Material Culture Commons, Archaeological Anthropology Commons, Environmental Studies Commons, Other American Studies Commons, Other Arts and Humanities Commons, Other History of Art, Architecture, and Archaeology Commons, and the United States History Commons

Tell us how this article helped you.

This Article is brought to you for free and open access by the Center for Regional Heritage Research at SFA ScholarWorks. It has been accepted for inclusion in Index of Texas Archaeology: Open Access Gray Literature from the Lone Star State by an authorized editor of SFA ScholarWorks. For more information, please contact cdsscholarworks@sfasu.edu. 


\section{The Archaeology and History of Alamo Plaza \\ Creative Commons License \\ (c) $($ ) (8)}

This work is licensed under a Creative Commons Attribution-NonCommercial 4.0 International License 


\title{
CENTER FOR ARCHAEOLOGICAL RESEARCH
}

\author{
Division of Social Sciences \\ The University of Texas at San Antonio \\ 78285
}

Thomas R. Hester, Girector

\section{EACULTY ASSOCTATES}

R. E, W. Adams

Fel $1 \times$ O. Almaraz, Jr. Jack. D. Eaton

ooe1. D. Gunn

Norman D. C. Hammend

1. Parker Nungey

\section{RESEARCH ASSOGIATES}

Fer 1 S A. Bass, Jr Anne A. Fox

paule. Ratz

Susanna R/Katz

Thomas C. Ke Jy

This is a reprinted version, with some corrections, of the report initially issued in 1976 .

Price: \$6.00 (add 30 d (f texas resident) 
TABLE OF CONTENTS

$\begin{array}{lc}\text { Table of Contents } & \text { Page } \\ \text { List of Figures and Tables } & \text { i } \\ \text { Preface } & \text { ii } \\ \text { Acknowledgments } & \text { iv } \\ \text { History of Alamo Plaza } & \text { v } \\ \text { A Pictorial Essay of the History of Alamo Plaza } & 27 \\ \text { Archaeology of Alamo Plaza } & 32 \\ \quad \text { Previous Archaeological Work } & 32 \\ \quad \text { Excavation Procedures } & 32 \\ \quad \text { Discussion of Features } & 51 \\ \text { Artifacts } & 53 \\ \text { Appendix } 2 \text { (Faunal Analysis) } & 85 \\ \text { Bibliography and Conclusions } & 79\end{array}$


THE ARCHAEOLOGY AND HISTORY OF

ALAMO PLAZA

Anne A. Fox, Feris A. Bass, Jr., and

Thomas R. Hester

Center for Archaeological Research The University of Texas at San Antonio Archaeological Survey Report, No. 16

1976 


\section{LIST OF FIGURES AND TABLES}

FIGURES

PAGE

1. Alamo Plaza

2. Alamo Plaza

3. The Menchaca Map of 1764

4. Map of Alamo, 1846

5. Plan of the Alamo in 1849

6. The Alamo and Surrounding Area in 1868

20

7. Alamo Plaza in 1904

24

8. Alamo Plaza

28

9. Alamo Plaza

10. Alamo Plaza

11. Location of 1975 Excavations

12. Plan of Excavations at Alamo Plaza, 1975

13. Location of Reference Point on Alamo Facade

14. Excavations in Alamo Plaza, 1975

15. Profile of West Wa11, Trench A

41

16. Profile of East Wa11, Trench B 44

17. Profile of South End, Trench B 46

18. Excavations in Alamo Plaza, 197549

19. Artifacts from Alamo Plaza 56

20. Artifacts from Alamo Plaza 59

21. Artifacts from Alamo Plaza 62

22. Ceramic Vessel from Alamo Plaza 65

23. Artifacts from Alamo Plaza 68 
24. Artifacts from Alamo Plaza

25. Artifacts from Alamo Plaza

26. Artifacts from Alamo Plaza

27. Conjectural Reconstruction of South Wall

TABLE

I. Provenience of Artifacts in Ditch 
PREFACE

In the Spring of 1975, the Center for Archaeological Research was approached by the Parks and Recreation Department of the City of San Antonio regarding possible archaeological and historical research at Alamo Plaza. The proposed investigations were in connection with the city's plan to renovate the plaza, to coincide with the American Bicentennial. There were two major reasons for the Center's involvement: (1) the architects desired to learn, as a part of the renovation plans, the precise locations of the south wall of the original Alamo (San Antonio de Valero) compound; (2) in order to aid in the planning of the renovation, it was necessary to determine if subsurface archaeological resources existed in Alamo Plaza. To achieve these goals, a contract was agreed upon between the City of San Antonio and the Center for Archaeologica1 Research at The University of Texas at San Antonio. A State Antiquities Permit (No. 94) was secured and all investigations were conducted under the terms of that permit.

The Alamo Plaza project was under the supervision of Dr. Thomas R. Hester, Director of the Center. In charge of the archaeological field work and historical research were Anne A. Fox and Feris A. Bass, Jr., both Research Associates of the Center. They were assisted by several Center employees and a number of volunteers, all of whom are acknowledged elsewhere in this monograph. During the period of the field work and in the subsequent period of analysis and report preparation, the Center's team worked closely with Mr. Ronald Darner, Director, Parks and Recreation Department, Mr. Emmit Tuggle, Project Architect, and $\mathrm{Mr}$. James Keeter, Landscape Architect for the project.

The field work portion of the project began on June 9, and continued until July 8, 1975. A period of intensive research, analysis, and manuscript preparation began with the close of field operations and continued into the Fall of 1975. This present report presents the results of this project. The section on the history of Alamo Plaza was authored by Feris A. Bass, Jr., and the section on the archaeology was written by Anne A. Fox. Other portions of the report are the collaborative efforts of all three authors.

Report preparation and editing were supervised by Thomas R. Hester, aided by Kathy McCauley, secretary for the Center. Illustrations are from various sources; maps and profiles were prepared by the field team (aided to a great extent by Daniel E. Fox). Final drafting was done in the UTSA Office of Instructional Services.

Thomas R. Hester

Director 


\section{ACKNOWLEDGMENTS}

No archaeological excavation can be undertaken without the help and cooperation of numerous people. The authors wish to express their sincere appreciation to the following individuals who gave of their time and interest to insure the successful completion of this project.

$\underline{\text { Crew }}$

John Arevalo

Anthony Christian

Jack Eaton

Daniel E. Fox

Arthur Uh1

Margarita Vazquez
Volunteers

Robin Barbee

June Carter

Robert Fox

Peggy Leifeste

Royce Mahula

Shirley Van der Veer

Migue1 Vazquez

Max Witkind

\section{Research Assistance}

Alton Briggs, Archaeologist, Texas Historical Commission

John Clark, Archaeologist, Texas Historica1 Commission

Sister Gertrude Cook, Archivist, San Antonio Archdiocese

Dr. Georgeanna Greer

Dora Guerra, Alamo Library

Charles Long, Alamo Museum

David McDonald, San Jose Research Library

Katherine McDowe11, Alamo Library

Sam Nesmith, Institute of Texan Cultures

Cecelia Steinfeldt, Curator of History, San Antonio Museum Association Curtis Tunnel1, State Archaeologist, Texas Historical Commission

Helen Weeks, Librarian, San Antonio Museum Association

\section{Expeditors}

Joe Blackman, San Antonio Parks and Recreation Department

Ronald Darner, Director, San Antonio Parks and Recreation Department

Ed Davis, San Antonio Parks and Recreation Department

Kenneth Graves, Tuggle and Graves, Architects

James Keeter, Landscape Architect

Emmit Tuggle, Tuggle and Graves, Architects

Steve Uncapher, San Antonio Parks and Recreation Department 


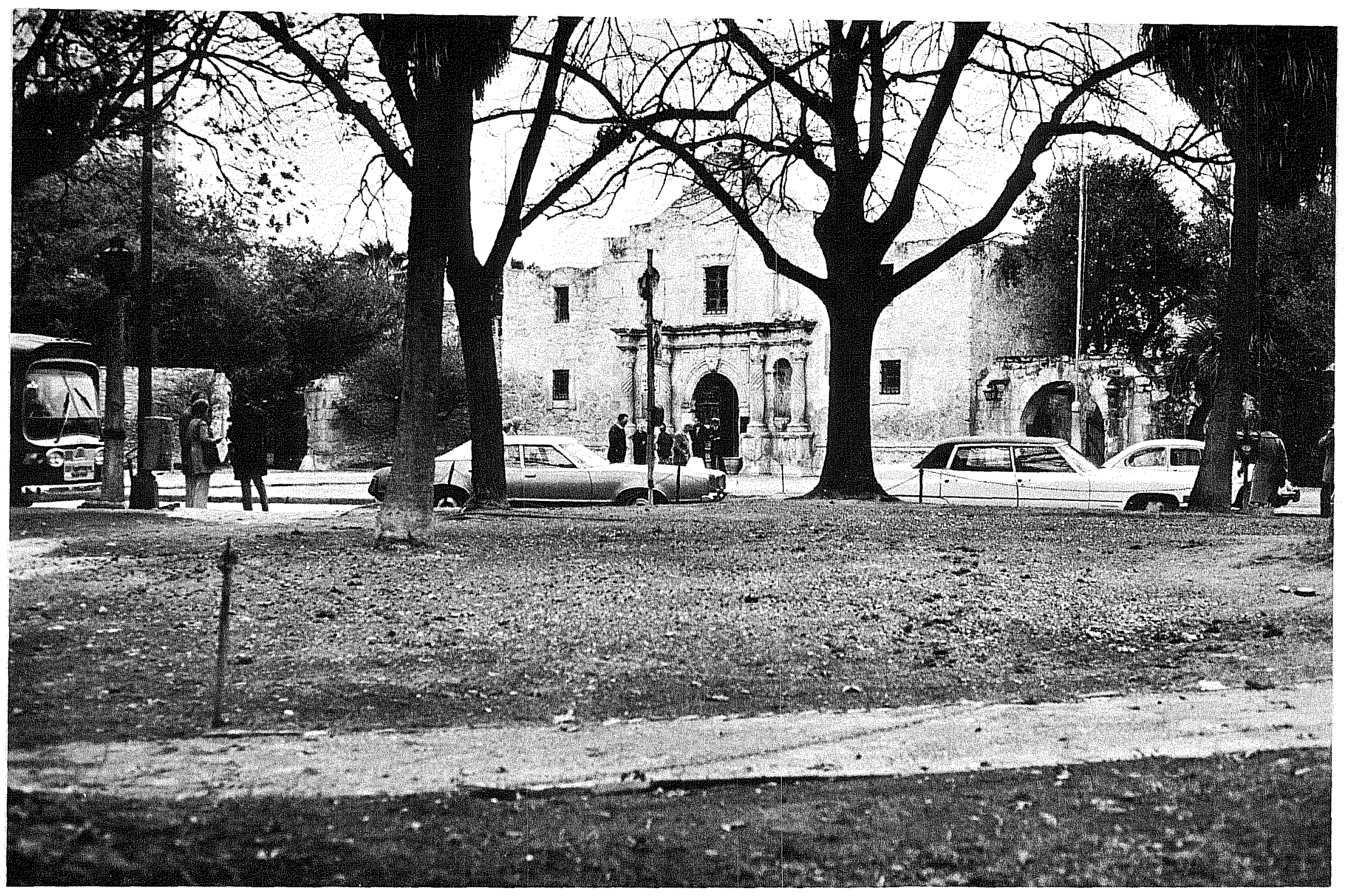

Figure 1. Alamo Plaza. The area in the foreground was the scene of the 1975 excavations. 


\section{HISTORY OF ALAMO PLAZA}

Spanish interest in Texas began in 1519 with Alvarez de Piñeda's cruise from Florida along the Gulf Coast to Tampico. However, for a variety of reasons, this interest was not accompanied by any tangible activity on the part of Spain until Sieur de La Salle made his inadvertent landing on the Texas coast in 1685.

The Spanish viewed this French intrusion as a threat to their colonial establishment in the New World and took immediate steps to neutralize any gains that might have been made by the French. This action took the form of a searching expedition by De Leon in 1689 followed quickly by three more expeditions culminating in the establishment of the Mission San Francisco at the site of the destroyed French Fort St. Louis in 1690. In 1691 additional missions were established on the Red River, the Neches and the Guada1upe.

These early missions were destined to failure because of the hostility of the Indians, the failure of the crops and the death of the cattle. The King was informed of these calamities and the recommendation was made that the settlements be abandoned because of their high cost of maintenance and lack of productivity. It was therefore decided to abandon these outposts in 1693 once more leaving Texas uninhabited by European settlers (Yoakum 1855, I: 45-46).

Spanish interest in this frontier province was kindled again in 1714 when another Frenchman, Louis Juchereau de St. Denis led a trading expedition into East Texas and finally to the Spanish presidio at San Juan Bautista on the Rio Grande. This incursion again alarmed the Spanish and in 1717 the Viceroy directed the reestablishment of Spanish missions in East Texas.

In recognition of the fact that one of the major reasons for the failure of the earlier missions in this area had been the lack of close and adequate support, the Viceroy ordered the establishment of a mission midway between the Río Grande and East Texas. The site chosen for this support mission was on the banks of the San Antonio River. To staff this new mission it was decided to move the trouble-plagued institution at San José on the Río Grande, to the new location (Barker 1929: 36-38).

This new mission was established May 1, 1718 and was named San Antonio de Valero in honor of Saint Anthony of Padua and the Marquis de Valero, the Viceroy of New Spain. A small fortified tower was built as a residence for the missionaries and the Indians were provided with crude huts. In 1724 this establishment was destroyed by a "furious hurricane" which levelled the huts and did "great damage" to everything (Barker 1929: 36-38). 
Rather than rebuild on a spot that had by then been recognized as less than desirable, the mission was moved to the present location. Considering the difficulties encountered, things seemed to go reasonably well for the new mission. By 1727 the construction of a convent was under way; three good sized cells and a granary of stone and adobe had been built and a fourth cell was under construction. In addition, other substantial huts had been completed for sleeping quarters and other purposes. The rancheria where the Indians lived had also been completed and an irrigation ditch (acequia) had been dug to about one league distance from the mission, making possible the cultivation of crops for the support of the mission inhabitants. The construction of this ditch had taken four years of effort by the missionaries and their charges (Barker 1929: 36-38).

By 1727 the population of the mission had increased to a total of 70 families from three nations, the Xarames (Aranamas), the Payayas, and Yerebipiamos (Ervipiame; Barker 1929: 36-38).

Plans were also made to build a stone church but actual construction was delayed because of a shortage of building materials and the unavailability of qualified masons to do the work. Efforts had been made to secure the latter but none had been willing to come to such a dangerous place to work. As a consequence, a large hut was being used as the church building (Barker 1929: 36-38).

In 1739 the mission experienced a calamity in the form of an epidemic, probably smallpox, that reduced the mission strength to 184 individuals. However, by 1740 the successful conversion of the Tacamanies (Tamiques) Indians saw the mission population increase to 261 people (Chabot 1931: 62).

Notwithstanding all of these setbacks, Fray Benito Fernandez de Santa Ana, president of the missions of San Antonio, wrote in 1740 that the mission at San Antonio de Valero was better able to withstand a siege than any of the presidios of the province (Bannon 1964: 199).

Though preparations were begun as early as 1727 for the construction of a stone and mortar church, sufficient materials had not been gathered until May of 1744 to permit the commencement of construction on the church and the cornerstone was laid on May 8, 1744 (Bolton 1907: 297). By this time the population of the mission had climbed to 311 Indians who occupied a pueblo consisting of two rows of small huts built on either side of an acequia. These huts were of adobe and were roofed with a straw thatch. Along each row of huts there was a sort of street and the whole complex was surrounded by a wall. The monastery had been completed, and though small, contained an upper story with three cells in which the missionaries lived. There was also a weaving room that had been completed and which was in use (Chabot 1931: 62; Castañeda 1938: 111-112). 
The pace of activity at the mission apparently did not appreciably accelerate with the commencement of the church, for by 1762 , it still had not been completed. In fact, it was in worse condition than at the start. Fray Mariano Francisco de los Dolores reported that the church tower had been completed, but had fallen in due to the inexperience of the builders. The sacristy was apparently under construction but still not completed. The housing of the Indians had been increased as seven rows of stone houses had been completed to form a plaza through which passed a ditch that had been planted with willow and fruit trees. A well had been dug and curbed with stone to augment the water supply in event of attack by hostile Indians. The ground and second floor of the monastery now had arcaded cloisters. A mud and stone wall enclosed this complex. At the gate in the south wall a tower was constructed with loop holes to facilitate the defense of the mission.

In his descriptions of the Indian houses Fray Dolores wrote: "The houses have doors and windows, elevated beds, chests, allotted metates, jars, comales, kettles, containers which are also kept in reserve in the offices to provide them when they ask because of their laziness and carelessness" (Schuetz 1966: 23-24). Further explanation for the slow progress of the mission is evident when we look at the personnel turnover that had occurred since its founding. Since that time, 1,972 individuals had been baptized, 454 marriages had been performed, and 1,247 people had been buried. There is no record of how many had left the mission compound. In 1762 there were 76 families 1iving at the mission with a total of $275 \mathrm{men}$, women and children. The fact that these residents represented seven different Indian nations certainly did not facilitate their administration (Schuetz 1966: 22-24).

The status of the mission was further clarified in 1765 when Fray Francisco Xavier Ortiz reported that the pueblo of the mission was composed of 30 adobe houses, 20 of which had doors and arches of stone, which in conjunction with the land of the church formed a beautiful and spacious street. He also indicated that there were other huts of a less permanent character (Ortiz 1955: 17).

An impression of the physical lay-out of the mission can be obtained by an examination of a map drawn by Luis Menchaca in 1764 (Fig. 3). Menchaca, military governor of the presidio of Bexar, had lived in the area for some time when he drew the map and it is compatible with the descriptions that are available. As is readily evident, the south wall of the mission compound is north of and parallel to the north wall of the church. The acequia is shown passing through the middle of the courtyard.

In 1772 the college of Nuestra Señora de Guadalupe de Zacatecas assumed control of the Queretaran missions in Texas (Webb et al. 1952, II: 568). 
It was in connection with this transfer that an inventory was made of the mission of San Antonio de Valero which includes the following description of the Indian quarters:

"The pueblo is made up of 5 rows of houses, each row has 3 houses and each house is 8 varas long with a door to the east and a window to the west. These houses have corridors or porches of stone arches for lighting and for the convenience of those who live there. Two other houses are found outside of those mentioned; they are without porches but are well built to protect against rain and wind."

Conditions had become so bad by 1789 that Fray José Francisco López, the Father President of the Missions in the Province of Texas, filed a pessimistic report with the Bishop of the New Kingdom of Leon expressing great disappointment with the directives he had received from the Government and the conduct of the local troops. He was particularly critical of the conduct of the Indians and was convinced they could not be persuaded to do any work even in their own support (Wallace and Vigness 1962: 29-35).

Fray López also described the Mission San Antonio de Valero as it existed at that time:

"...It is built to form almost a square, surrounded by a single stone and mud wall that stands about 300 (?) paces from the center. The same rampart serves as a wall for most of the fifteen or sixteen houses, with ample capacity for lodging the Indians. Nearly all the houses are covered with wood and mortar, as a protection against the rain, and have hand-carved, wooden doors with locks and iron keys. Within the square is the granary, made of stone and lime, which has enough room to hold two thousand fanegas ( $4000 \mathrm{bu}$.) of corn, two hundred or more fanegas of beans, etc. Next is the house or living quarters, adequate for the missionary and the officers of the community, made of stone and lime, with good roofs, doors, windows, and locks. Adjoining this building is the sacristy (which serves today as the church), while another room now serves as the sacristy. Both structures are of stone and mortar and are built with arched roofs. This mission has under construction a church with a very large nave whose walls are built as high as the cornices, but the latter have built only in the dome of the presbytery. In the front, its beautiful facade of wrought stone has been completed to the same height as the walls. At this point the construction stopped many years ago for lack of qualified workmen. For this and other reasons.... it cannot now be carried to completion." (Wallace and Vigness 1962: 29-35). 
In addition to these internal problems, the activities of the hostile Indians placed even heavier burdens on the operations of the mission. In 1785 the Comanches became so aggressive that even the troops assigned to protect the mission were compelled, for safety, to remove their tents within the mission walls (Yoakum 1855, I: 107).

Faced with nearly insurmountable problems it is not surprising that control of the mission was passed to secular authorities at the earliest opportunity. This occurred with the issuance of a royal decree in 1792. Transfer of responsibility was completed in 1793 with the movement of mission records to the Archives of the Villa of San Fernando and the distribution of mission lands to the Indians that were resident at that time. As was typical of such transactions an inventory was made of the mission property which provides a final glimpse of the physical aspects of the mission.

"... On the east side of the irregular rectangle of the mission ran a wall from north to south 165 varas. The south wall ran east and west 58 varas. Both walls were 3 varas high and $3 / 4$ varas thick made of stone and adobe and mud. Half the north wall was in ruins. The main gate that led to the plaza through the south wall measured 5 varas in width and 4 in height. Within the enclosure completed by the church and mission bulldings were the houses of the neophytes. Adjoining the Padre's quarters was a building 30 varas long, 5 wide and 7 high, with adobe floor. This was the barn. ...There was also a large jacal, also a storeroom. Most of the Indian quarters faced the archway along the western wing. Only 12 were habitable. The others were in ruins. The church had not been completed." (Casteñeda 1942, V: 44).

Following secularization the buildings of the mission were stripped even of their doors and locks and were unoccupied from 1793 until 1801 (Chabot 1941: 14; Bexar Archives).

As early as 1792 France had begun to lay plans and to enter into intrigues that were designed to regain her old possessions in the new world and which led her to acquire Louisiana from Spain as a base for her schemes. When these failed and the Louisiana territory was sold to the United States, a new flurry of activity was created that was to force reconsideration of the use of the mission buildings.

With all of this excitement to the north and on the borders of the Texas province, action was taken by the Spanish governor to strengthen the defense of the province. On December 29, 1802 the Flying Company of San Carlos de Parras del Alamo was assigned to the settlement at San Antonio. On its arrival the company was assigned to quarters in the old mission of San Antonio de Valero which was unoccupied at the 
time. Since the area was still threatened by hostile Indians, barracks were erected along the south side and inside of the old mission enclosure (Smith 1966: 8).

The arrival of the troops, and a very practical concern by the Spanish government over their welfare, was a motivating factor in the establishment of a hospital at the Alamo in 1805. The old mission buildings had now come to be called the Alamo because of the name of the military company occupying that facility.

Colonel Bustamante in a letter to the Governor General reporting the opening of the hospital said:

"...I have provided, without any cost whatever, and availing myself only of a little arbitration, the equipment of a party ruined chamber in the secularized Mission of Valero as a military infirmary. I have had it provided with beds made of reeds in order to avoid the dampness of the ground. The patients of all the companies or posts who may be sent here will be placed in them under the necessary care of a nurse (male), a woman to take care of the kitchen and guard of the company of the Alamo which is stationed at that mission. The only expense entailed will be the increase of the troops one real and a half per day to two reales, and the remuneration of the doctor and cost of medicines" (Nixon 1936: 17).

In 1806 the hospital was improved with 30 beds fully equipped; and, in 1807 authorization was granted for "the construction of two rooms in the abandoned mission of Valero, to the end that they may serve as the pharmacy of the military hospital which has been temporarily established there" (Nixon 1936: 17). In 1809 further repairs became necessary and were duly reported and approved, though for much more than could have been required for the hospital alone. Experts employed to survey the requirement recommended that a new roof and gutter be installed, that the floors upstairs and down be repaired, that the chinks in all the walls be filled with small rocks and mortar, and that 834 varas of battlement be constructed of concrete and plastered with mortar (italics mine). Master masons Juan Diego Velos, Juan de Dias Cortez and Francisco Zapata were employed to make an estimate of the requirements to complete the job. These were, among other things, 2,000 barrels of lime, 820 cartloads of sand, 16,995 shingles and 12 beef hides to make leather straps for tying scaffolds. The work was approved and was completed early in 1810 (Nixon 1936: 27-28).

The basis for the extended requirements for the "repair of the hospital" were no doubt related to information that had been received by Nemecio Salcedo, the Commandant General of the Northeast Provinces of New Spain.

On January 6, 1809, it was reported that 4,000 troops had been dispatched to New Orleans by the United States Government; and that 50,000 troops 
were to be placed under the command of General James Wilkinson on the Texas-Louisiana border (Castañeda 1942, V: 364).

This information had been transmitted to Salcedo's nephew, Manuel Salcedo, the Governor of Texas. This warning had been transformed into action by the preparation of a defense plan for the province which called for the establishment of fortifications at San Antonio. These fortifications would then serve as the principle stronghold to which the Spanish troops could retire in the event of invasion, "so that they could better check the further advance of the enemy until reinforcements could arrive" (Castañeda 1942, V: 379).

The activity of the Salcedos was not unwarranted as a threat did exist. However, neither of the two had forseen the true danger to the security of New Spain and especially that of the province of Texas. Almost simultaneously with the strengthening of the Bexar fortifications, Miguel Hidalgo y Costilla gave forth with his grito at the village of Dolores and the Mexican Independence movement was under way. By early 1811 Manuel Salcedo, a staunch royalist, noted the rapid deterioration of Spanish control along the Rifo Grande, and decided to employ the forces at his disposal to attempt to stem the tide of revolutionary success. On the second of January he publicly announced that the companies would soon leave for an important mission on the Río Grande. This announcement was met with considerable grumbling, fueled by the efforts of rebels among the Bexar residents who spread the rumor that Texas was to be abandoned, that the Bexar residents were to be left behind defenseless, and that the barracks at the Alamo had been ordered burned (Garrett 1939: 39-40).

On the evening of January 21,1811 , the rebels struck. The leader, Juan Bautista Casas, a retired captain, established his headquarters at the Alamo.

The unrest on the Texas-Louisiana border, fueled by the internal revolution in New Spain and the influx of a number of Mexican rebels, began to crystallize into a more dangerous form. On August 10, 1812, an expedition led by José Bernardo Maximiliano Gutiérrez and William Agustus Magee entered Texas from Louisiana. After a series of victorious encounters with the Spanish troops in Texas, the invaders entered the town of San Antonio de Bexar on April 2, 1818 and occupied the Alamo as their headquarters (Garrett 1939: 178; Yoakum 1855: 168).

The confusion that had prevailed during the Mexican Independence era, and the attempt to establish the Republic of the North, had prostrated the settlement at San Antonio de Bexar (Yoakum 1855, I: 183). By 1814 the old mission of Valero was in sad need of repairs. It was necessary to order the thatching of the Indian quarters and the monastery for use of the troops quartered there. The acting Governor sent out an urgent appeal for aid in purchasing materials for reconstruction. At the same time he ordered the Royal Alcaldes at 


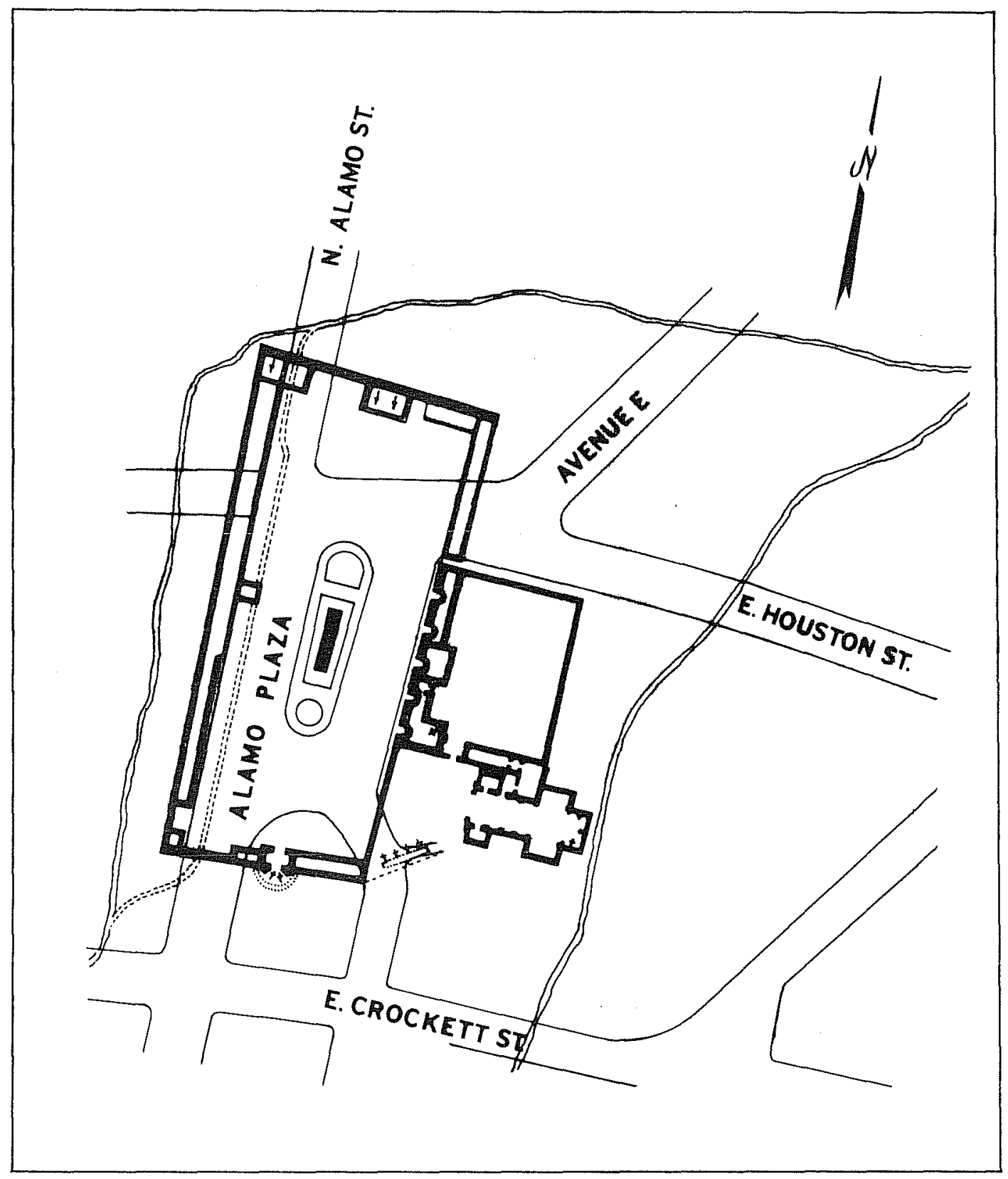

Figure 2. Alamo Plaza. Alamo Plaza, showing lines of walls and buildings at time of Alamo battle, as drawn by Green B. Jameson early in 1836, superimposed on modern San Antonio streets. 
the mission to request all dwellers having ox-carts to help the military by hauling materials for repairs (Castañeda 1950, VI: 128). But even with this effort, by 1816 San Antonio de Bexar was nearly deserted (Yoakum 1855, I: 183).

Following Iturbide's assumption of the Mexican throne in 1821, conditions at San Antonio began to improve because of the large number of troops that had been assigned to the town. The population of the community had climbed to approximately 5000. But even with this development, the town was still visited by the Comanches, and when they were there they were masters of the place (Yoakum 1855, I: 221). With the influx of troops the problem of housing arose once more. On November 5, 1823 the secretary of the Ayuntamiento, forwarded a petition to the Ayuntamiento requesting that the small houses along the mission walls of valero be put up for sale as soon as the barracks were built for the soldiers (Castañeda 1950, VI: 321).

Even so, it appears that as late as 1825 the troop housing problem still had not been solved, for the Commander of the Alamo Garrison was requesting that the quarters of the former Valero priests be assigned permanently as barracks for the Alamo soldiers. Before action could be taken on the request, orders arrived directing the immediate sale of all remaining mission property. This latter directive was immediately opposed by Anastácio Bustamante, the Captain General of the Provincias Internas, who demanded the suspension of the order as he desired the mission buildings as permanent quarters for : his troops (Castañeda 1950, VI: 349). This action by Bustamante must have been successful as a sizeable community of more than 300 had sprung up in the vicinity of Valero by 1829 (Ibid: 351).

No record was located of any modifications or other activity with respect to the buildings or facilities at the Alamo during the late $1820^{\prime} \mathrm{s}$ or early $1830^{\prime} \mathrm{s}$. Perhaps the reason for this is that the Government of Mexico was in a state of turmoil and internal revolution during the period and had little time to worry about such a remote and comparatively insignificant problem. However, since Bustamante had been the one to direct the preservation of the Alamo for use as barracks it is reasonable to assume that it was used for this purpose during the period of his presidency. It is also probable that little was done to improve the facilities when it is realized that the Mexican Government preferred "vagrants and disorderly persons" to staff the Bexar military company (Yoakum 1855, I: 55).

We do know that with the arrival of Martin Perfecto de Cos at Bexar in 1835, the Alamo was occupied by his troops during the defense of San Antonio against the attack by the Anglo-American colonists in December of that year. Samuel A. Maverick in his diary states that Cos put the Alamo into "fort fashion" by building a dirt incline up to the top rear of the church wall, covering it with planks to make an artillery ramp. On this position he placed an 18 pounder cannon. 
A half dozen other cannons were also mounted in the Alamo. One of

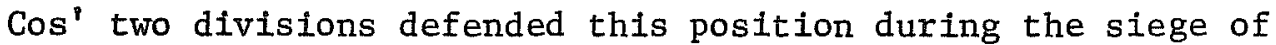
December, 1835 (Weems 1971: 47). It was also during this period that Cos probably erected the cedar palisade and ditch from the southwest corner of the church to the barracks on the south wall (Chabot 1941: 24).

Cos apparently constructed a number of these fortifications in preparation for the defense of the town. The specifications are interesting from an archaeological standpoint. They were made by cutting a trench about eight feet deep behind which two rows of piles about six feet apart were sunk into the ground. The space between these piles was filled with the dirt from the trench and the piles were tied with rawhide rope. At each of the places so fortified there was a stationed piece of artillery (Ibid).

Following the defeat and surrender of Cos the Texas troops that remained in San Antonio under the command of Colonel Neill occupied the Alamo. Sam Houston, the newly elected commander of the Texas Army, did not believe that it offered a defensible position with the troops available. For this reason he dispatched James Bowie with 30 troops to San Antonio to carry an order to Neill to destroy the fort at the Alamo and to fall back and join him. He was also to remind Neill to bring with him all of the artillery that had been captured from Cos (Yoakum 1855, II: 58). This order was not carried out because, according to Neill, he did not have the necessary teams to pull the artillery.

With the decision to remain, elaborate plans for the strengthening of the fort were made; but apparently little more than a few simple modifications were made.

In his book on the Alamo, Chabot says, "There is no doubt that this work, such as it was, was carried on in a very irregular way, the officers themselves doing much of the actual labor. ...The army of the Alamo had practically no organization of a strictly military nature" (Chabot 1941: 33). Apparently a well was dug in the plaza area and a parapet was built to strengthen the north wall of the plaza (Chabot 1941: 37; Jenkins 1973, IV: 352).

At the time of the Battle of the Alamo, Castañeda states that the following was its configuration:

"From the northwest corner of the chapel a 12 foot wall ran west for 50 feet to the barracks, a two story structure, 186 feet long by 18 feet wide by 18 feet high. ... From the northeast corner of the church a wall ran 186 feet north and 102 feet west to join the long barracks and thus form a patio and inner court. A strong stockade had been built from the southwest corner of the chapel to the low barracks, a one story building, 114 by 17 feet, which comprised part of the south wall. Half of the building was used as a prison and the remainder as soldiers 
quarters. Other low buildings formed part of the west wall. The enclosure to the west of the chapel formed a quadrangle 154 by 54 feet. The north wall was somewhat longer than the south wall" (Castañeda 1950: 288).

For an eyewitness view of the fortress just prior to the battle, we have the account of William S. Oury who was a messenger from the Alamo just before it fell. His description is:
"The chapel was in ruins from neglect. Long ago the roof had caved in but it was still a staunch fortress, strongest...building in the compound. Directly in front of the chapel was a small courtyard, divided from the long rectangular court by a low wall. The south east portion of the smaller yard, open when the Mexicans held the fort, was now closed by a $10 \mathrm{~g}$ palisade and some earthworks stretching from the baptistry corner of the church to the south wall" (Smith 1967: 21).

Santa Anna, the Mexican commander, described the condition of the Alamo fortress following the battle:
"The fortifications were badly damaged from the siege and most of the buildings were in ruins. A short time later General Vicente Filisola sent orders to Andrade to demolish the Alamo's fortifications, render them use- less for all times and under any circumstances, and to spike the guns captured from the enemy" (Castañeda 1928: 202).

These latter instructions to Andrade were actually carried out and were witnessed by $\mathrm{Dr}$. J. H. Barnard, who had been sent to San Antonio after his capture at Goliad. In his journal he describes what happened:

Sunday 22 May 1836

"General Andrade has received orders to destroy the Alamo and proceed to join the main army at Goliad. The troops have hitherto been busy in fortifying the Alamo. They are now as busy as bees, tearing down the walls etc..." (Huson 1949: 43).

Tuesday 24 May 1836 (6:00 P.M.)

"As the troops left town this morning, a large fire streamed up from the Alamo. ...We found the fire proceeding from a church where a platform had been built extending from the great door to the top wall on the back side. ... This was made of wood and was too far consumed...to extinguish it. ...The Alamo was completely dismantled, all single walls were leveled, the fosse filled up, and the pickets torn up and burnt" (Ibid: 45). 

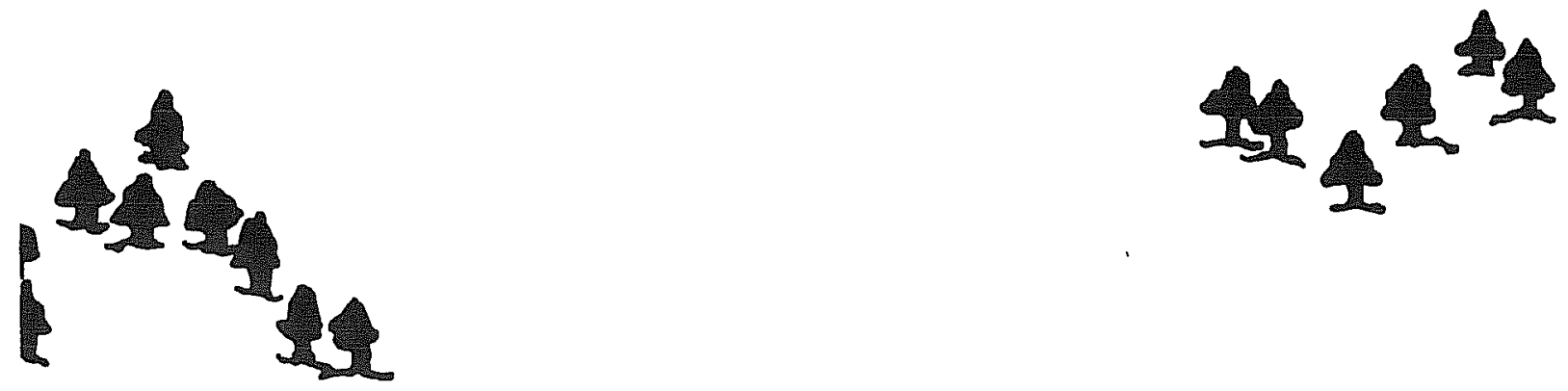

M. de S. Antonio

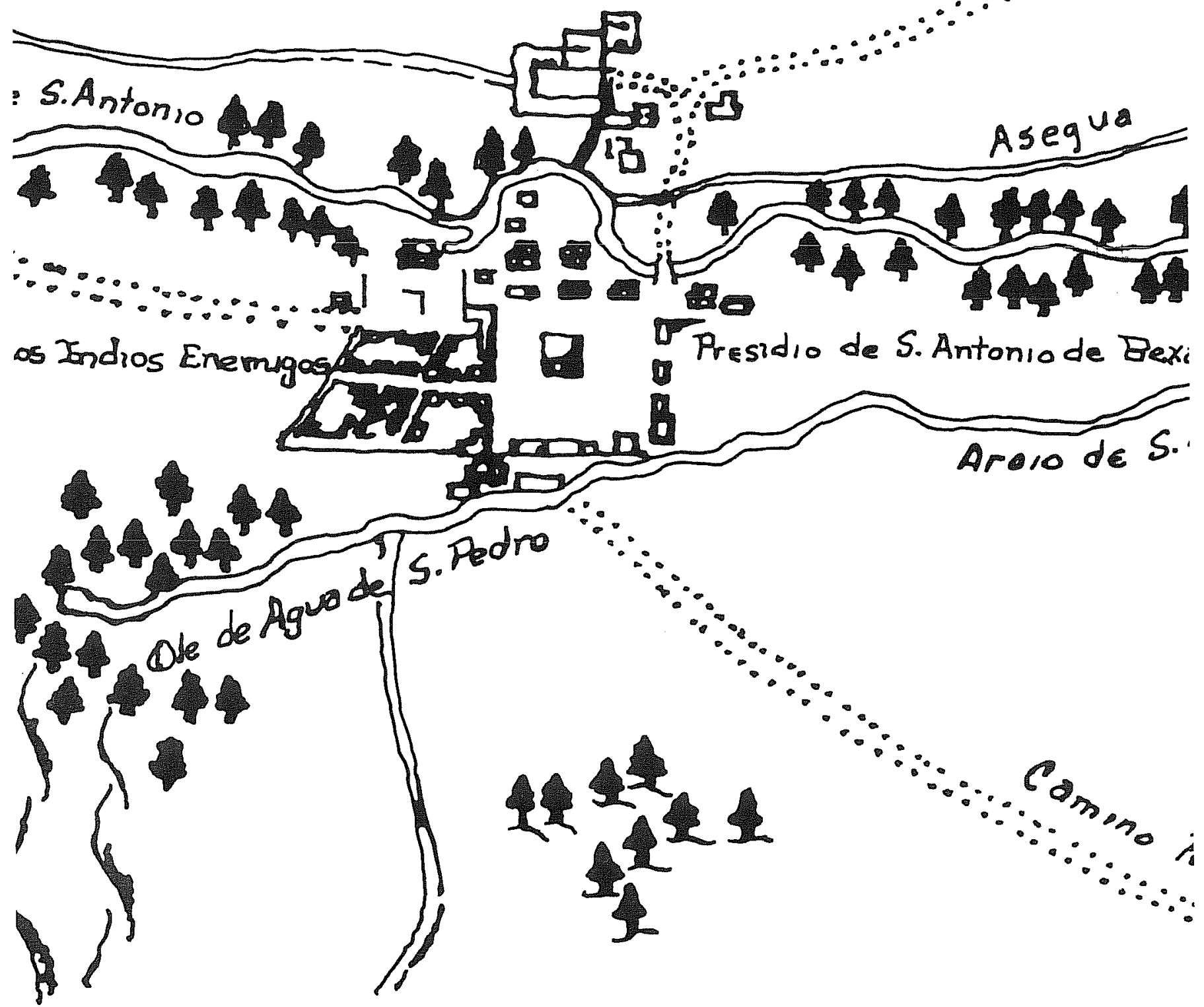

Figure 3. The Menchaca Map of 1764. Copy of a portion of a map of San Antonio and vicinity drawn by Captain Luis Antonio Menchaca in 1764. (After Schuetz 1966:

Figure 2). 
Following the destruction of the Alamo and the retreat of the Mexican Army, the Alamo was deserted and remained vacant and unclaimed until 1841. At this latter time the Congress of the Republic of Texas, by an Act of January 13, 1841, declared the property to be that of the Roman Catholic Church. This ownership was again confirmed by the Supreme Court of the State of Texas in its November term of 1855 (San Antonio vs. John Odin, Supreme Court, Austin, November term, 1855).

Some idea of the degree of abandonment of the old mission can be gained from the journal of John Mary Odin who on a visit to San Antonio in 1840 wrote in his October 6, 1840 entry: "At 10:00 A.M., a party of Indians were seen near the 'Alamo' and one Mexican killed. His name was Manuel Diaz." Odin went on to write that between January 1, 1840 and October 12, 1840 that a total of 38 Mexicans and 14 Americans had been killed by the Indians in the vicinity of San Antonio (Odin 1840-1852: 6). This picture is further expanded by Judge J. M. Rodriguez in his memoirs in which he states:

"There were no buildings fronting on the west side of Alamo plaza except a few jacals, all mesquite posts. ...Alamo plaza itself contained nothing more than the convent, some old broken down walls and ruins" (Garza 1913).

William Bollaert, who was in San Antonio at that same time, wrote: "Not half the walls are now to be seen and those grown over with weeds, moss and even shrubs growing out of the cracks in its walls" (Holton and Butler 1956: 224).

Six years later in 1846 things had not improved as William A. McClintock (1930: 144-145) wrote:

"The castle is an irregular parallelogram built of large blocks of soft limestone finely cemented together. A wall formerly enclosed the fortress, courtyard, offices etc. containing an area of about one acre of ground. This wall has the appearance of having been in a state of utter ruin for a long time past and is only discernable from the heap of rubbish elevated a few feet above the surrounding plain."

With the annexation of Texas to the United States and the commencement of the Mexican War, the United States Army began to take a keen interest in the military assets of this newly acquired territory. Lt. Edmund Blake, perhaps rushing things a bit, was mapping the area along the Río Grande and in South Texas as early as 1845. In conjunction with this project Blake drew a sketch of the ruins of the Alamo as he found them. The following year Edward Everett prepared a plan of the ruins of the Alamo indicating the existing portions of the old fort (see Fig. 4). 
In 1849 San Antonio was chosen as the headquarters of the Eighth Milftary District and Major E. B. Babbitt, acting Quartermaster, took possession of the Alamo buildings in the name of the United States Government for use as a quartermaster depot. At that time the ownership of the property was in dispute, no doubt brought to focus by the Army's interest. Both the City of San Antonio and the Catholic Church claimed title to the property. When the Quartermaster moved in on January 2, 1849, the city demanded rent for the buildings but later on January 16 offered to provide them rent free. The Church, on the other hand still demanded $i$ ts rent of $\$ 150.00$ a month which it continued to collect while the Army occupied the buildings. In addition to the rent that was paid, Babbitt spent $\$ 5,800.00$ to put the buildings into habitable condition (Conner 1945: 8; Archdiocesan Accounts).

Some idea of the extent of the military operation can be gained when it is noted that by 1853 there were 124 wagons and teams owned by the Army that were in daily use between the port at Indianola and the depot at the Alamo and between the depot and other posts. These were in addition to the civilian contract wagons and teams which could often be quite numerous. Among the latter were Mexican carts which were hired to accomplish some of the more difficult transport tasks. Such was the case in 1849 when it became necessary to supply the 3rd Infantry at $E I$ Paso at a time when there was insufficient grass to support the regular teams (Babbitt 1849; Conner 1945: 19).

With all this traffic to and from the Alamo, the plaza was an extremely busy place. This condition was officially recognized in 1865 with an ordinance passed on November 8 of that year:

"...All wagons and Mexican carts remaining in the business portion of the city, unless loading or unloading shall be driven to Military Plaza or Alamo Plaza or Plaza de Valero. ...but no wagon, cart or other vehicle shall remain upon said plaza or either of them all night" (Smith 1966: 31).

In 1850 Joseph Addison Hatch passed through San Antonio to join the French Expedition going to California. His account of the Alamo and the activities surrounding it provide an interesting insight:
"There were 400 of us left in San Antonio on that expedition, and we loaded our wagons at this old Alamo. At this time there was no Hugo and Schmeltzer building there at all. The roof was on the Alamo, and the Government was using it for a commissary. It had a floor above at that time, which was used for storing supplies. There was an old adobe wall running from the Alamo to about where the Menger now stands which was broken and crumbled in parts, and the old wall that had stood where the Hugo and Schmeltzer building now stands was also crumbled and broken in parts. 
Figure 4. Map of Alamo, 1846. This map of the ruins still standing in 1846 was drawn by Lt. Fdward Everett, who was a member of the Wool expedition to Saltillo. Everett also drew detailed sketches of the Alamo Church, of Missions Concepción and San José, and two views of structures near Monclova. Lithographs made from these sketches were included in the "Memoir Descriptive of the March of Brigadier General John E. Wool from San Antonio de Bexar, in Texas, to Saltillo, in Mexico", Report of The Secretary of War, 31st Congress, Ist Session, Executive Document No. 32, 1849. 


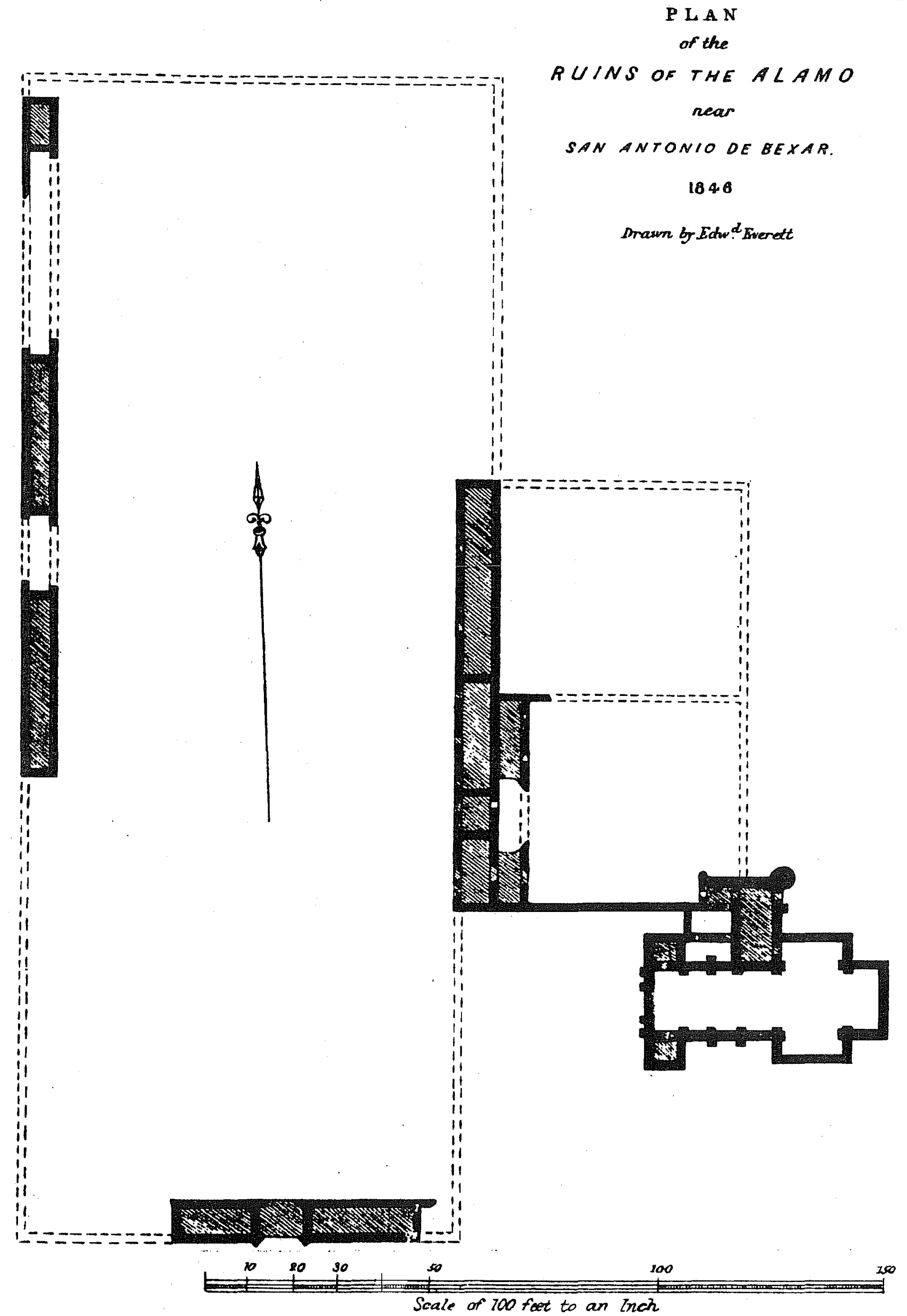


There was a ditch running back of the Alamo where we watered our horses. Major Babbitt was in command. There were a few soldiers and they were going out on the frontier. ...Where the post office is now situated, in 1848 there was a garden and there was no Houston street laid out at that time" (Hatch 1910).

In 1854 Lt. Col. W. G. Freeman conducted an inspection of the Quartermaster Depot at the Alamo. In his report he wrote:
"This branch of the San Antonio Depot now and for some time past under the charge of Bvt. Major James Belger, Asst. Quartermaster occupies the extensive pile known as the 'Alamo Buildings' and an adjoining lot of ground. Title to the former is in dispute, but the property is leased from Biship Odin of the Roman Catholic Church at $\$ 150.00$ per month, $1-1-50$ to continue in force during the pleasure of the United States, when given up, the improvements are to resort to the lessor. The lot is rented from S. A. Maverick at $\$ 200.00$ per month for ten years from 10-1-51...The terms of these two leases are considered highly favor- able. The buildings and premises are admirable adapted to their purpose; storage for supplies is ample and secure and by the workshops, stables, storehouses, rooms and offices being brought together, a stricter vigilance can be exercised" (Freeman 1853).

In the process of placing the buildings in useable condition, Major Babbitt became the individual responsible for the facade of the Alamo as we know it today (Smith 1966: 25).

The stationing of the Army at Alamo Plaza had the effect of making it economically more attractive-to others. As indicated, both the city and the Church had responded quickly, and others were to follow. It is not known for certain but it is probable that the Army's interest was the motivation for a survey initiated by the city (see Fig. 5). The surveyor, F. Giraud, was the close friend of a local entrepreneur, S. A. Maverick, who was quick to recognize the potentialities of the area. It was perhaps for this reason that Maverick is said to have persuaded Giraud to modify his survey to permit Maverick to acquire some of the Alamo property (Ramsdel1 1959: 76-77; Smith 1966: 33). Having made this rather basic arrangement, Maverick built his home fronting on the old plaza. Little more than a few old Indian huts and a few jacals fronted on the plaza until William $\mathrm{H}$. Menger built his house and brewery in 1855 (San Antonio Light, February 1, 1959; Newcomb 1926: 73).

Development of the plaza area was not to be as fast, however, as some had believed, for in 1856 Frederick 0lmsted wrote the following description: 


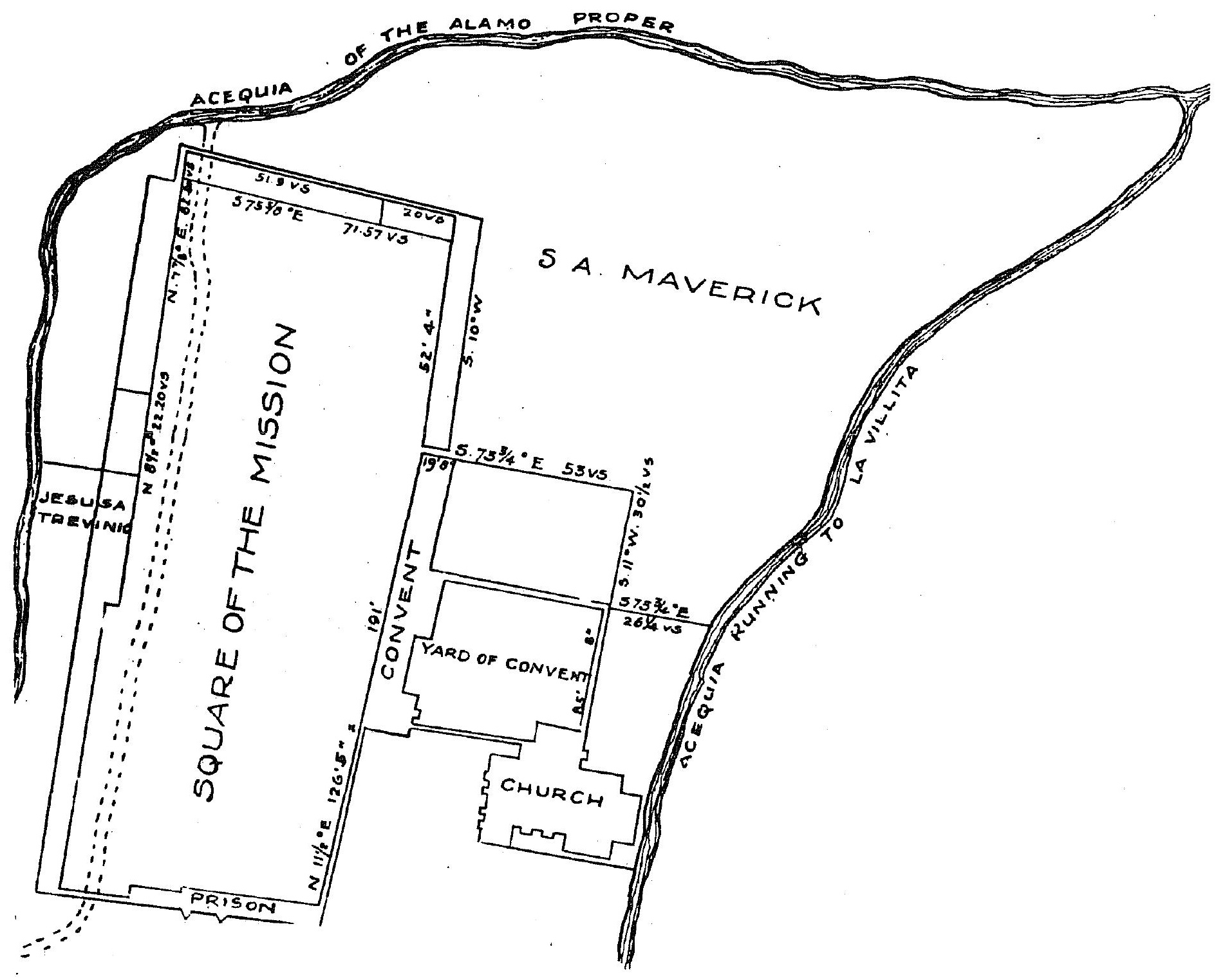

Figure 5. Plan of the Alamo in 1849. Taken from a plat recorded in Book 1 , p. 114, In the City Engineer's office, representing a survey of the Samuel A. Maverick tract made in December, 1849, by F. Giraud, City Surveyor. 


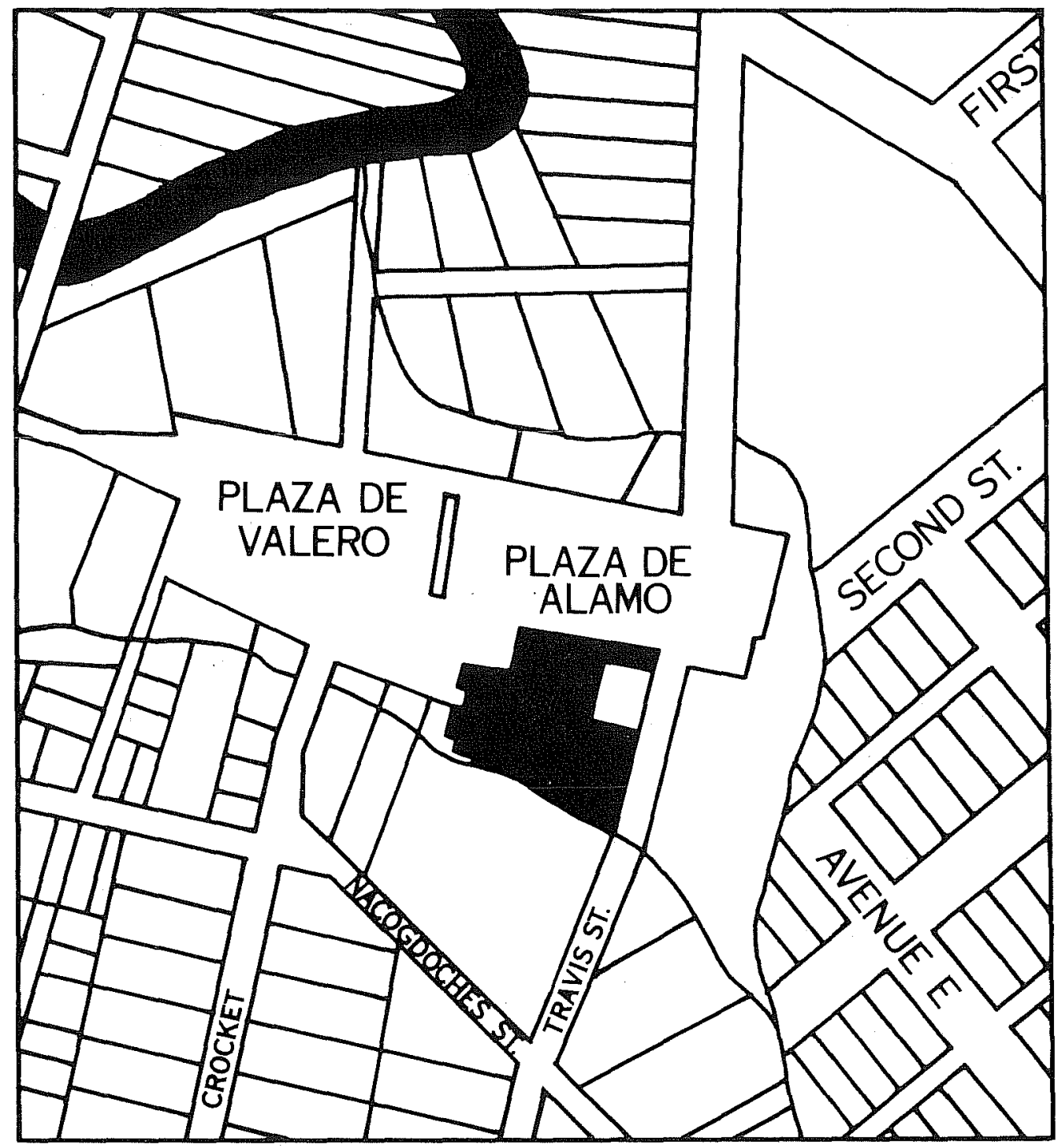

Figure 6. The Alamo and Surrounding Area in 1868. Copy of a section of a map of the City of San Antonio located at the National Archives in the Records of the War Department, Headquarters of the Army, Descriptive Book of The District of Texas, July 1, 1868, No. 220, Map No. 5. 


\begin{abstract}
"This is all Mexican, windowless cabins of stakes, plastered with mud and roofed with river grass, or 'tula' or low, windowless, but better thatched, houses of adobe (gray unburnt bricks), with groups of brown idlers lounging at their doors" (Olmsted 1856: 149).
\end{abstract}

In 1859 Menger opened his hotel next door to the Alamo depot apparently to accommodate the growing number of visitors having business with that facility. Also on the plaza there had begun to appear a row of small houses on the west side of the plaza. Some of these were shops, but most of them were houses to accommodate the military personnel who were on duty at the depot. A market house in the middle of the plaza had been constructed to serve the occupants of the area (Smith 1966:

It was in 1859 that "The Alamo Guards" were mustered and William M. Edgar was appointed Captain. The organization had 120 members and its armory was the Alamo. While Edgar was still Captain, the Secession Convention was held with Sam Maverick as chairman. Maverick, following the decision to secede, issued orders to Captain Edgar to seize the safe, funds, and effects of the United States in the possession of Captain Reynolds, the Quartermaster of the Federal Government. The Alamo then became the quartermaster depot of the Confederate Army in Texas and remained so until the conclusion of the war and the return of the United States Army in 1865. Not much is known of activities at the Alamo during the Confederate tenure, except that it was during 1861 that two smal1 boys "who were smoking cigarettes" set fire to some loose straw with the result that the entire interior of the church was burned. At that time the church had a wooden roof which burned and fell in and the entire building had to be repaired. A portion of the front (west) wall fell to the ground and an entirely different one had to be bullt (Conner 1945: 47). Following the war, the United States Army regained control of the Alamo and remained there until 1879 (Conner 1945: 11).

After 1865, more and more activity began to center in the plaza area. There was a growing recognition of the need to improve the condition of the area. It was probably in view of this need that the City of San Antonio sought to clean up the debris that still littered the plaza from the days of the Alamo siege. The old galera building (originally the barracks and gate complex) still separated the north and south portions of the plaza which were, for a time, designated as Alamo Plaza on the north and Plaza de Valero on the south (see Fig. 6). In 1866 the clty began clearing these ruins but was halted by the Catholic Church which still claimed title to the property on which they were situated (Texas Material Microfilm, Notre Dame Archives, Rol1 1). The controversy that arose continued for some time with added pressure from the citizens of San Antonio urging the removal of the old ruins. The San Antonio Daily Express of March 7, 1869 (p. 3) carried the following comment: 
"The Alamo Ruins--Why are the ruins opposite the Alamo Church left standing like a grim phantom, with its ghastly smile, looking out for relief, but all in vain. These ruins should be looked after, and demolished."

In the meantime there had been considerable discussion in the town throughout the $1850^{\prime}$ 's and $60^{\prime}$ s regarding the condition of the plaza. During rainy weather it was a quagmire and people who went about at night were forced to carry a lantern to prevent them from falling into a mud hole (James 1938: 94; Newcomb 1926: 93).

An attempt was finally made in 1871, after the city had purchased the galera property from the Church for $\$ 2,500.00$ (General Warranty Deed on file at Catholic Archdiocese) to remove the ruins and improve the conditions of the plaza. The San Antonio Daily Express carried the following story on September 14, 1871:

"A suggestion--We notice the debris of the old building on Alamo Plaza is being removed by the city. Directly in front of the long building, near the old Alamo Chapel, is a pond, or at least its a pond for weeks after it rains. Would it not be a good idea to fill it with the earth that is being removed. The people in the immediate vicinity would look upon it as a favor."

By the late 1870's Alamo Plaza had become a booming locality. It was the center for transportation entering and leaving the city. The Menger Hotel had already been built and by 1877 there were eight saloons fronting on the plaza to accommodate the weary travelers. Most of the other businesses located there were transportation-oriented.

In this same year Honore Grenet, a native of France and a businessman, bought the old convento and its courtyard from the Catholic Church (Deed Records of Bexar County, Book 7, p. 213). He remodeled the old structure and converted it into a building resembling a fortification. It was a two-story edifice with a quadrangle on the east side, enclosed on the south by the Alamo, the museum he operated in conjunction with his store, and the wine and liquor departments. On the east and north side of the quadrangle was a frame building used as a warehouse.

In June of 1878 the City of San Antonio began the operation of its first public transportation system with the inauguration of a street railway with its terminus at the market building on Alamo Plaza. According to the City Directory of 1879-80, "the road has been built in a thorough manner and rock ballasted throughout" (Newcomb 1926: 97; San Antonio Light, October 4, 1962).

It was also during this period that the Post office appeared on Alamo Plaza. It was located in the new Gallager building that had been erected at the south end of the plaza where Joske's department store now stands. The Post office opened on December 22, 1877. This brought many more people to the plaza and was no doubt a factor in establishing it as a center of city life (Smith 1966: 51). 
But even while this development was in progress, the Army was already considering moving the depot operation away from its Alamo location, an action that was to be completed in 1879 with the completion of the Fort Sam Houston Quadrangle (Conner 1945: 58, 87). To facilitate this move the Army moved a part of its operation into the new Maverick building that was completed that same year (Ibid).

In spite of all these new developments it appears that as late as 1877 the appearance and condition of Alamo Plaza had not been noticeably improved over that which has been previously noted, for in that year a weekly paper was still editorializing on the subject:

"Let the square before the Alamo be improved and ornamented, let it bear the stamp of civilization; let a suitable monument be erected." (Newcomb 1926: 93)

The neighborhood was still apparently badly neglected because after every rain, pools of water stood in front of the Alamo and the plaza was "a mere bog, a convention place for frogs" (Newcomb 1926: 93). This may have been the reason the city decided in 1882 to move the market house away from the plaza (Freeman 1972).

By the following year a unified effort was under way to try and improve the plaza area. As a step in that direction the State of Texas purchased the old Alamo church from the Catholic Church on May 16, 1883. The purchase price was $\$ 20,000.00$ (Chabot 1941: 52). This action seems to have been the necessary catalyst to bring about the desired change. By 1886 the new Grand Opera House was completed almost directly across the plaza from the Alamo (Smith 1966: 39). It was this same year that the Grenet building was sold to the Hugo and Schmeltzer Company for $\$ 28,000.00$ paving the way for its eventual removal. In 1877 two public water closets and privies were erected (Journal and Minutes of Council, City of San Antonio, Vo1. G., 1888: 287).

By 1889 the whole character of Alamo Plaza had changed. The City Council had approved and constructed four paved streets around the plaza. These streets were 60 feet wide and were paved with mesquite blocks. Sidewalks were constructed in front of the Alamo and the owners with property fronting on the plaza were required to build "Class A" sidewalks in front of their property (Smith 1966: 40). Furthermore, the waterworks company was directed to connect pipes to the center of the plaza for the use of a fountain (Journal and Minutes of Council, City of San Antonio, Vol. G., 1888, p. 536). Concurrently the character of the business establishments on the plaza had also changed so that by 1890 most of the transportation-oriented businesses were gone and had been replaced by amusement halls, clothing stores, professional people, land agents, restaurants and saloons (Smith 1966: 58-59). By the following year the plaza had been transformed from an unsightly mud hole into a garden circle, or park, laid off in an artistic manner and planted with trees, rare shrubs, roses and other flower bearing plants (Ibid: 41; Fig. 7). 
Figure 7. Alamo Plaza in 1904. Redrawn from Insurance Report of Sanborne Map Company located in Rare Book Collection of Chapman Center at Trinity University. 
Alama Plaza 1904
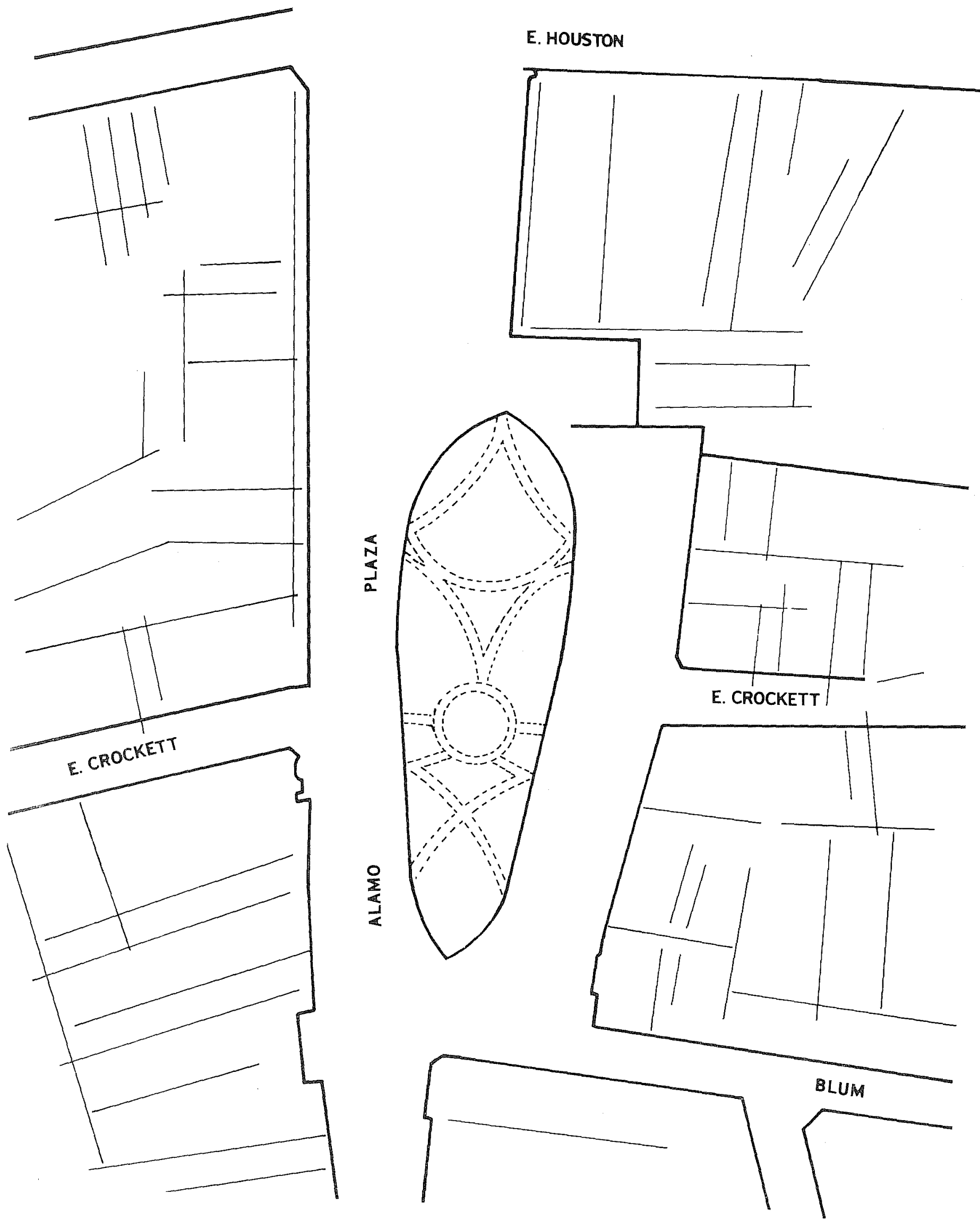
This progressive step seems to have been the necessary element to finally expedite the development of the plaza area. The Hugo and Schmeltzer building was condemned by the City of San Antonio in 1889, perhaps as the beginning of a movement, that was well developed by 1893, to restore the plaza to a pre-1836 configuration and condition (Chabot 1941: 52-54).

In 1904 the Daughters of the Republic of Texas, aided by Clara Driscoll who bought the Hugo and Schmeltzer property for $\$ 75,000.00$, set about to preserve the Alamo as a Texas shrine. In 1905 the State of Texas assumed the purchase designating the Daughters of the Republic of Texas as guardians of the property (Ibid).

There followed a period of controversy among the Daughters themselves, and between their organization and the Governor of Texas, as to the form the preservation of the Alamo would take. The disputes were finally settled in 1915 and steps were taken to restore the buildings of the old mission to approximately their present condition (Story 1938).

But other developments occurred on the plaza itself. In 1890 a new Post Office was opened on the north end of the plaza which was later torn down and replaced in 1937 by a newer and more modern federal building (Smith 1966: 51). In 1910 the streets on Alamo Plaza were resurfaced with asphalt (Pioneer Flour Mill 1951). In 1915 the old bandstand was torn down and the present one was erected (date on cornerstone). In the mid-1920's, Crockett Street was opened through the park that had been laid out in the plaza in 1889. In 1934 the area immediately in front of the Alamo Church and the south garden was widened, planted, and curbed. The final major modification to the plaza was the erection of the Alamo Cenotaph which was dedicated on November 11, 1940.

In the 257 years since Padre Olivares brought his small company to the banks of the San Antonio River, there have been many changes in the character and the activities on the ground now known as Alamo Plaza. Because of the many obstacles which confronted the early missionaries, it is now clear that the physical development of the mission was exceedingly slow and the mission structures were not even completed at the time of its abandonment in 1793. Most of the structural remains that we now call the Alamo, in a11 probability, attained their present configuration, and in many cases their initial existence, after the end of the mission phase. 
A PICTORIAL ESSAY OF THE HISTORY OF

ALAMO PLAZA

The following 1llustrations indicate the changes that have occurred in the area of Alamo Plaza over the past 140 years. We are grateful to the Alamo Library for permitting us to copy and reproduce these illustrations, the originals of which are to be found in the files of that institution. 

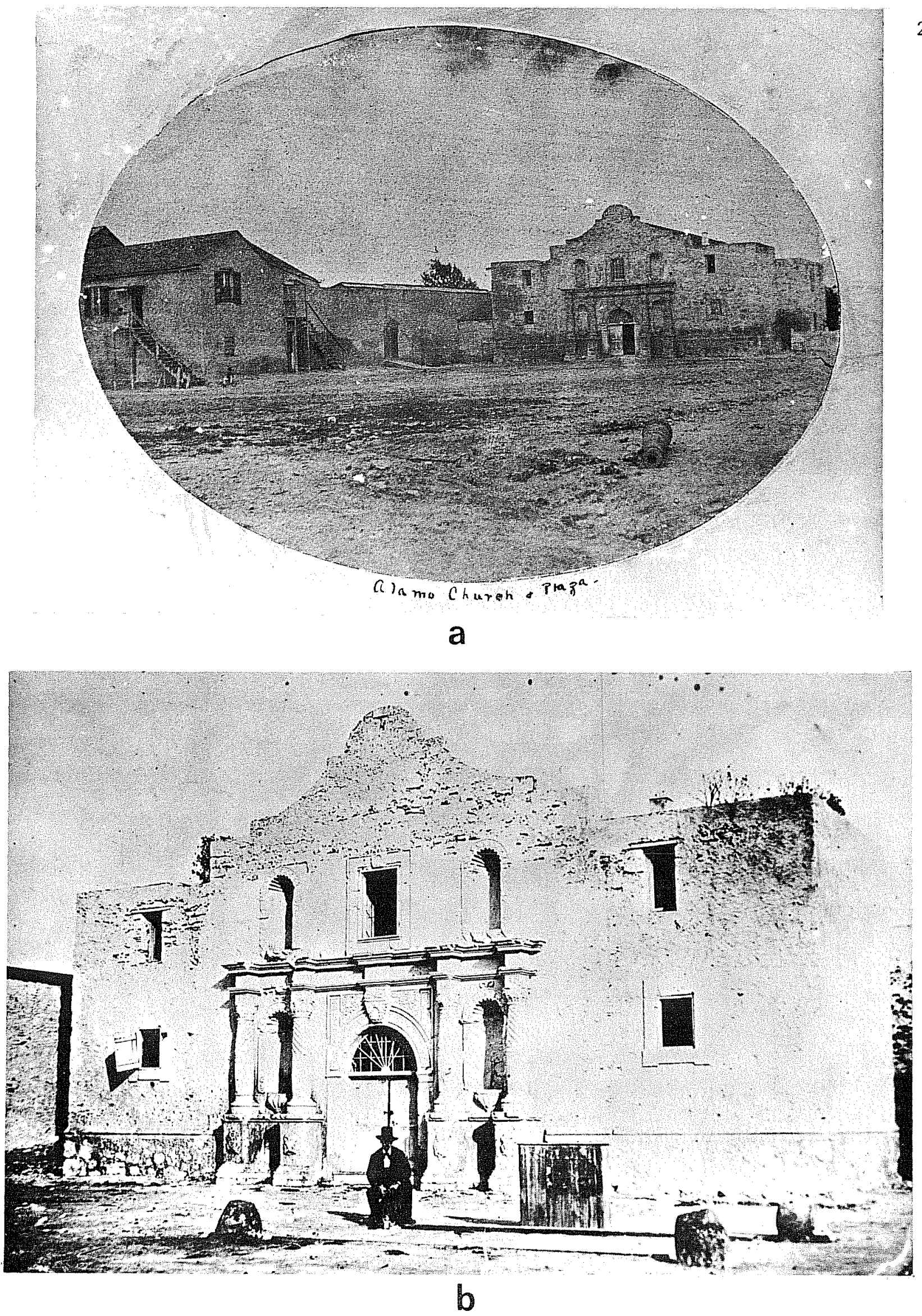

Fígure 8. Alamo Plaza. a, Alamo Church and Plaza, 1850's; b, view of the Alamo in the $1860^{\circ} \mathrm{s}$; wagon scales are situated in the foreground, in front of the seated man. 


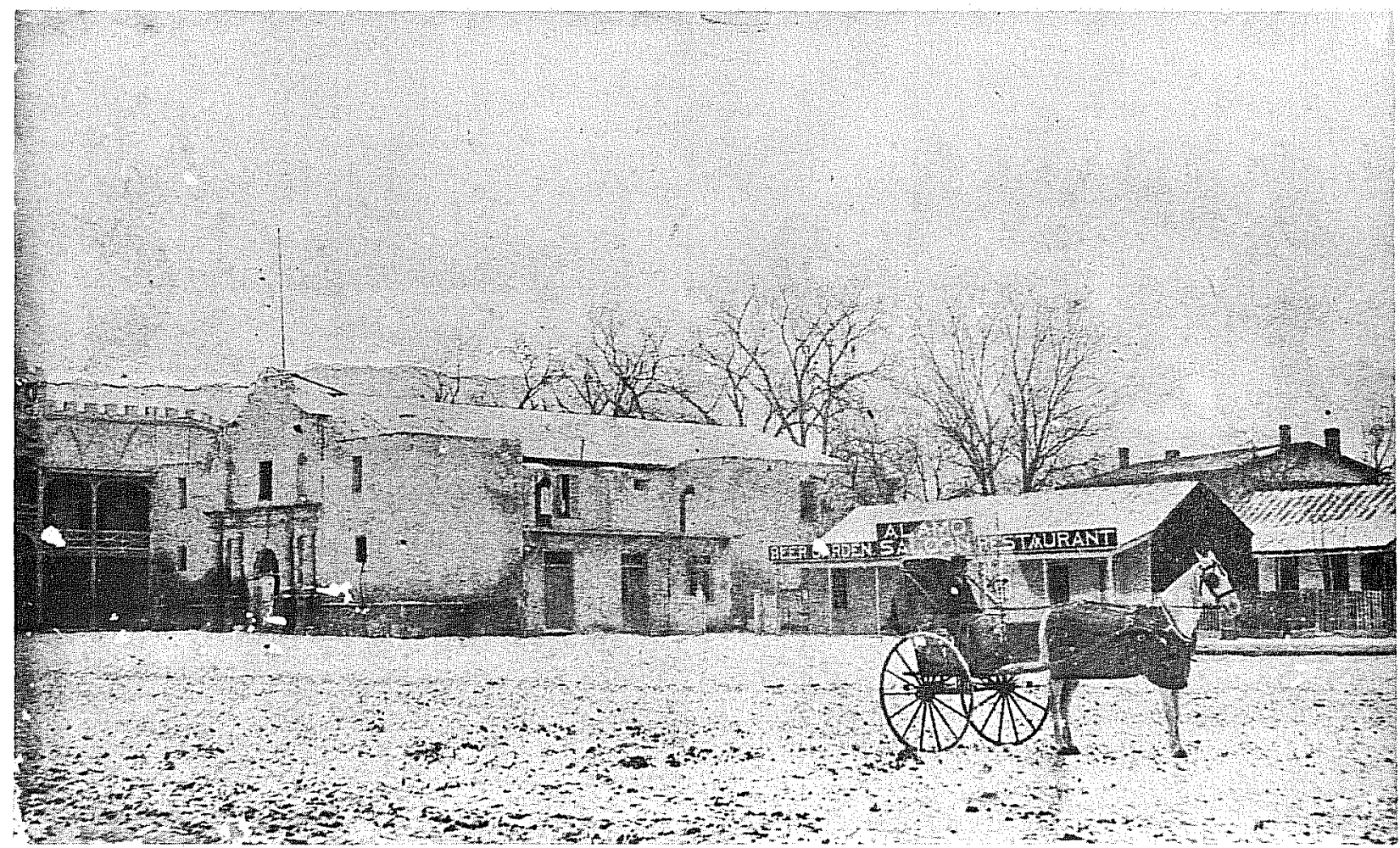

a

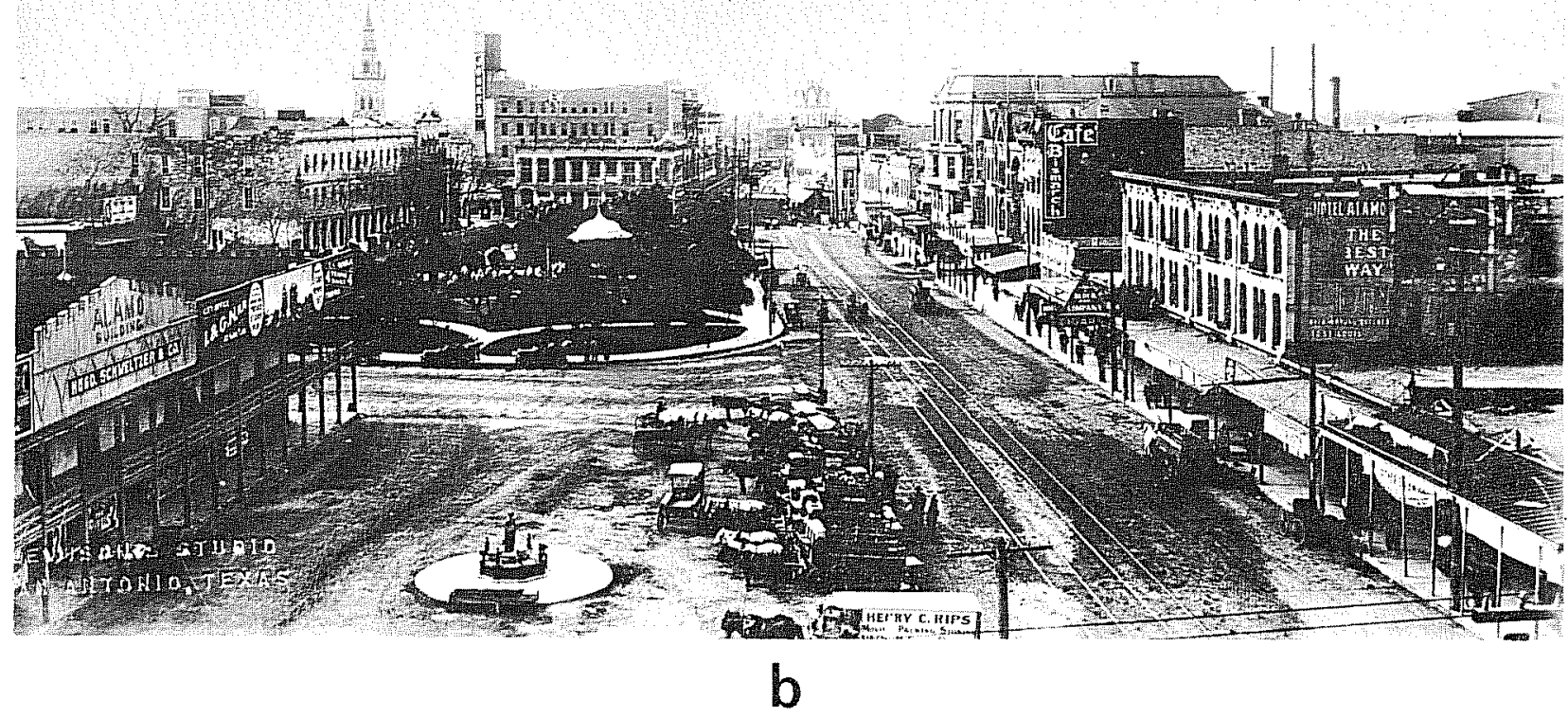

Figure 9. Alamo Plaza. a, view of the plaza in the 1880 's; b, view dating from 1900; note the Hugo, Schmeltzer and Co. store on the left and the bandstand in the trees at center left. 
Figure 10. Alamo Plaza. Various photographs taken in: a, 1913; b, 1927; c, 1935. 

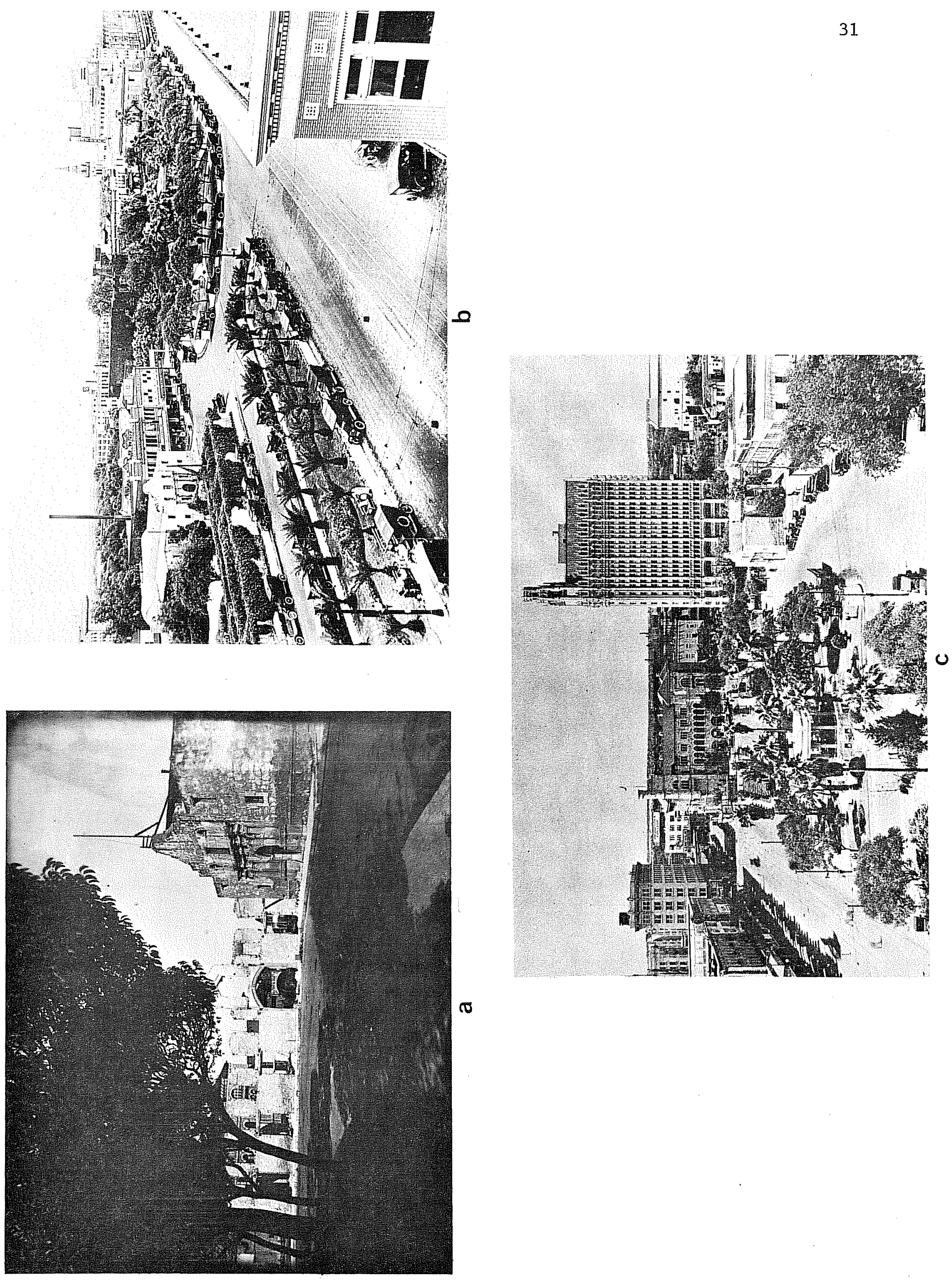

$\pi$ 


\section{ARCHAEOLOGY OF ALAMO PLAZA}

\section{Previous Archaeological Work}

A number of archaeological excavations have been carried out on the grounds of the Alamo within the past ten years, revealing that there is considerable information to be gained about the history of the area from remains still preserved in the ground. In June of 1966, work by a crew under the direction of John Greer in the convento area yielded much valuable architectural and artifactual information (Schuetz 1966; Tunnell 1966; Greer 1967). Further excavations in the Second Patio in 1973 by Mardith Schuetz added more to the knowledge of structures in the area (Schuetz 1973). Investigations carried out north of the DRT Library building in 1970, under the direction of William M. Sorrow, revealed footings of 19 th century structures and the location of the acequia which ran east of the chapel (Sorrow 1972). In November of 1973 a group of graduate students from The University of Texas at San Antonio, under the direction of Thomas R. Hester, investigated an area east of the museum bullding in the vicinity of the same acequia (Adams and Hester 1973).

\section{Excavation Procedures}

Excavation was begun on June 9, 1975, and continued through July 8, 1975. The crew consisted of two research archaeologists, two graduate students, two laborers, and numerous volunteer workers.

The first and most important objective of the investigation was to determine how much evidence of the south wall of the mission compound and its related buildings was preserved, and if possible to locate these structures accurately for future interpretation within the plaza. The fact that many of the trees in the park have grown to truly magnificent size during 80 years of park development severely limited the possibilities for excavation. After careful study of maps of the area today and as it was in the early 19th century, an area nine by thirty meters, within which we predicted the walls would 1ie, was staked out by the archaeological team. Trenches A and B (Fig. 12) were then laid out across this area so as to intersect both wall lines. The angle of the trenches was dictated by the need to avoid the principal tree root systems and existing water lines.

Preliminary excavation was done with the aid of a City of San Antonio backhoe, attempting to determine how much overburden had accumulated through park construction and maintenance since the 1ate 19th century. By careful control of depth and continuing examination of backhoe trenches, it was possible to remove the overburden to a point just above where it appeared that there were still remnants of stone 
Figure 11. Location of 1975 Excavations. The location of the 1975 excavations in Alamo Plaza are shown in relationship to other features in the area. Dimensions indicated (Genti1.z, Giraud) are referred to in the text. 


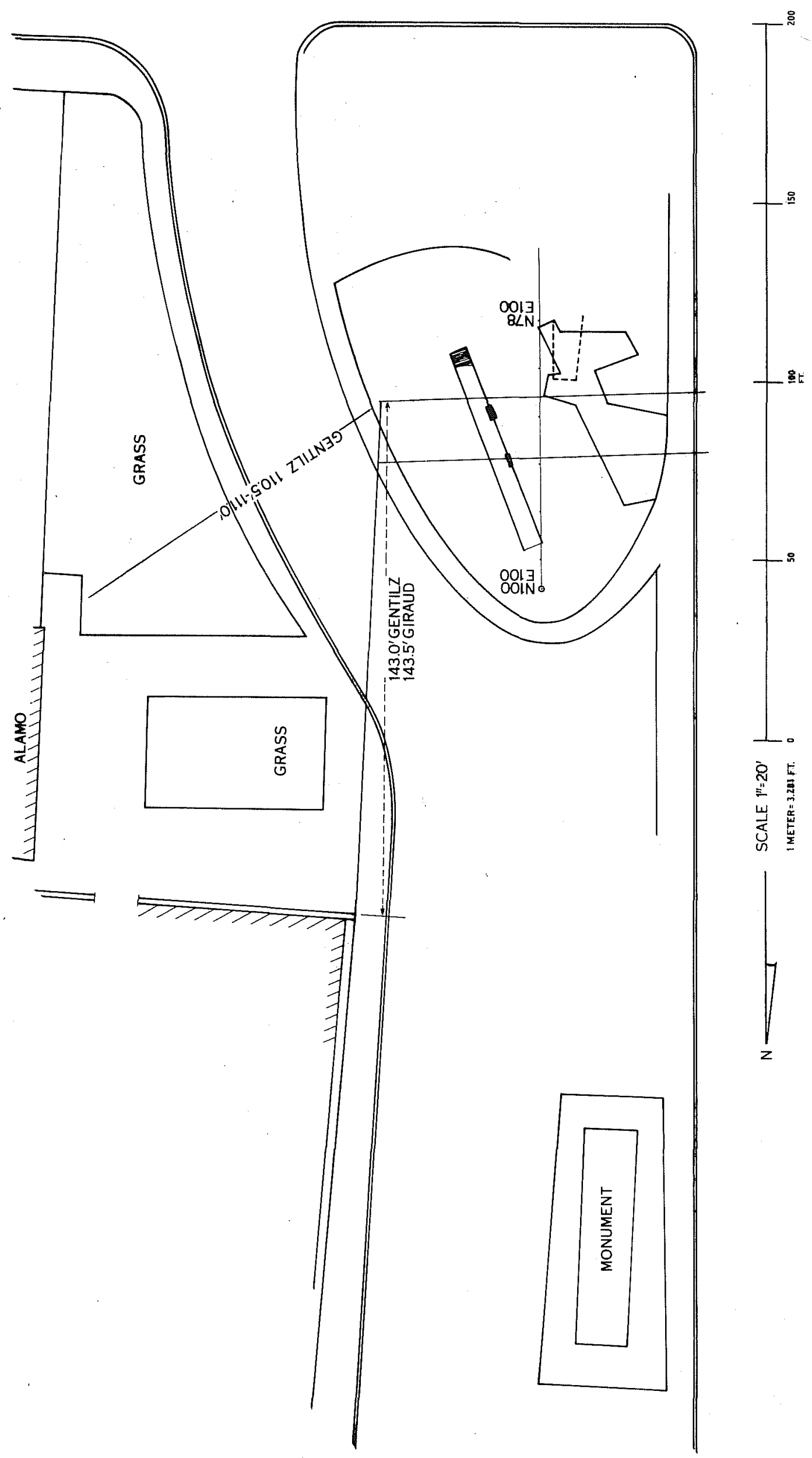


Figure 12. Plan of Excavations at Alamo Plaza, 1975. The areas of hatching represent remains of early structures revealed by excavations. The parallel lines between trenches $B$ and $C$ represent the location of an intrusive trench dug in the late 19 th or early 20 th centuries. 


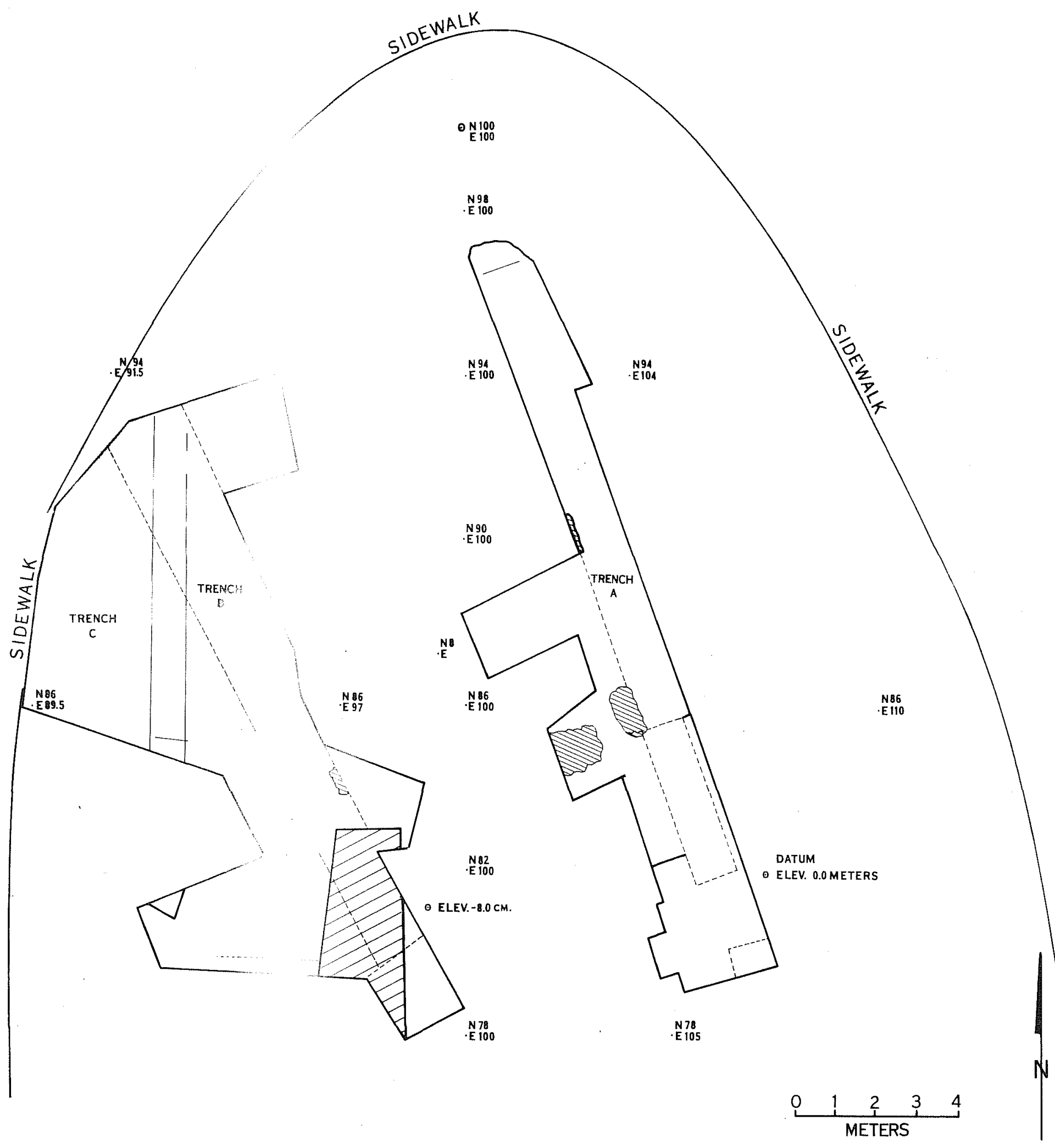



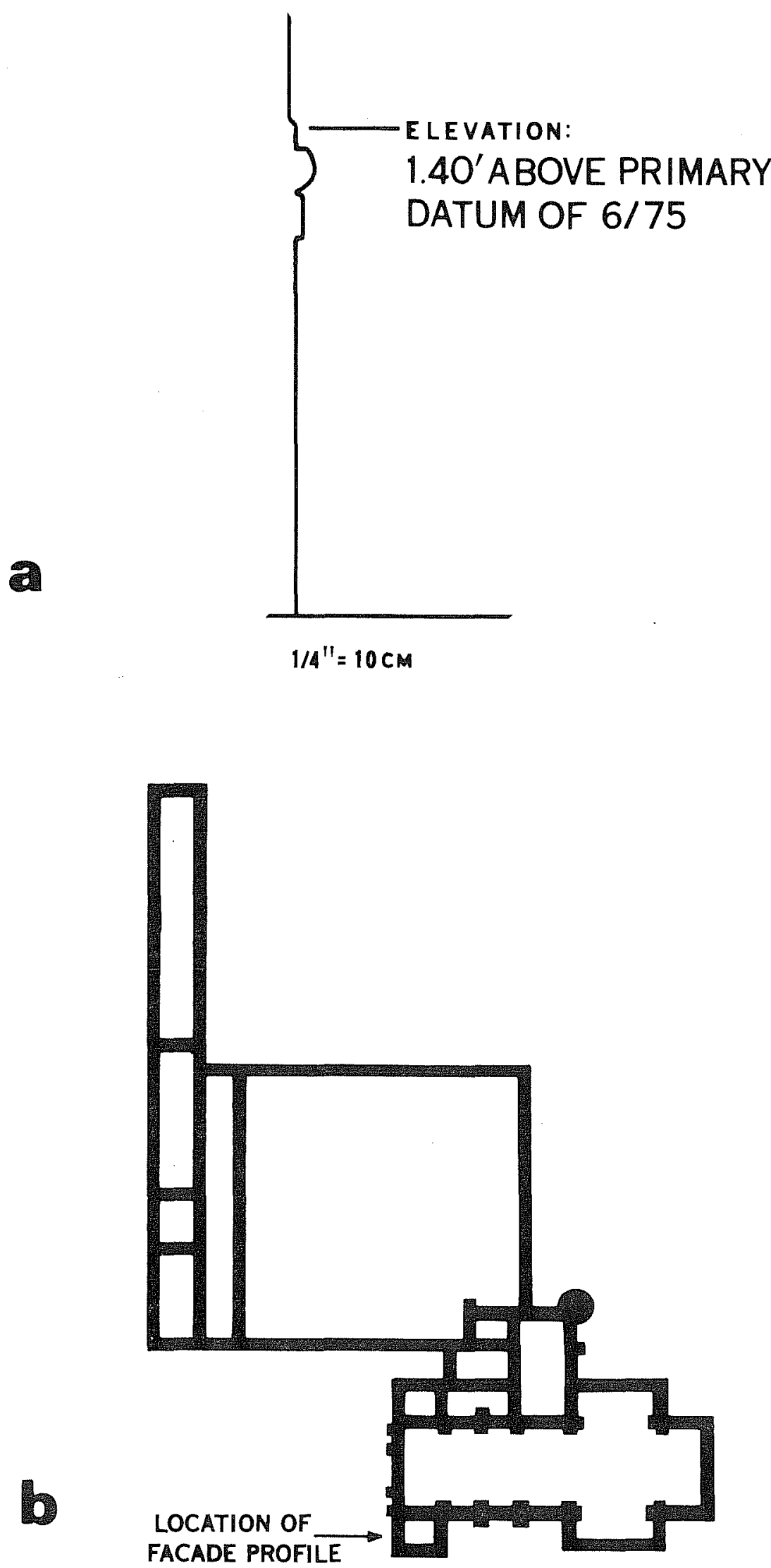

Figure 13. Location of Reference Point on Alamo Facade. a, profile view of location of reference point and its elevation above primary datum (see Fig. 12); b, plan showing location of a on the facade of Alamo chapel. 
Figure 14. Excavations in Alamo Plaza, 1975. a, Trench A looking northwest; $b$, south wall footing in west profile of Trench A. 

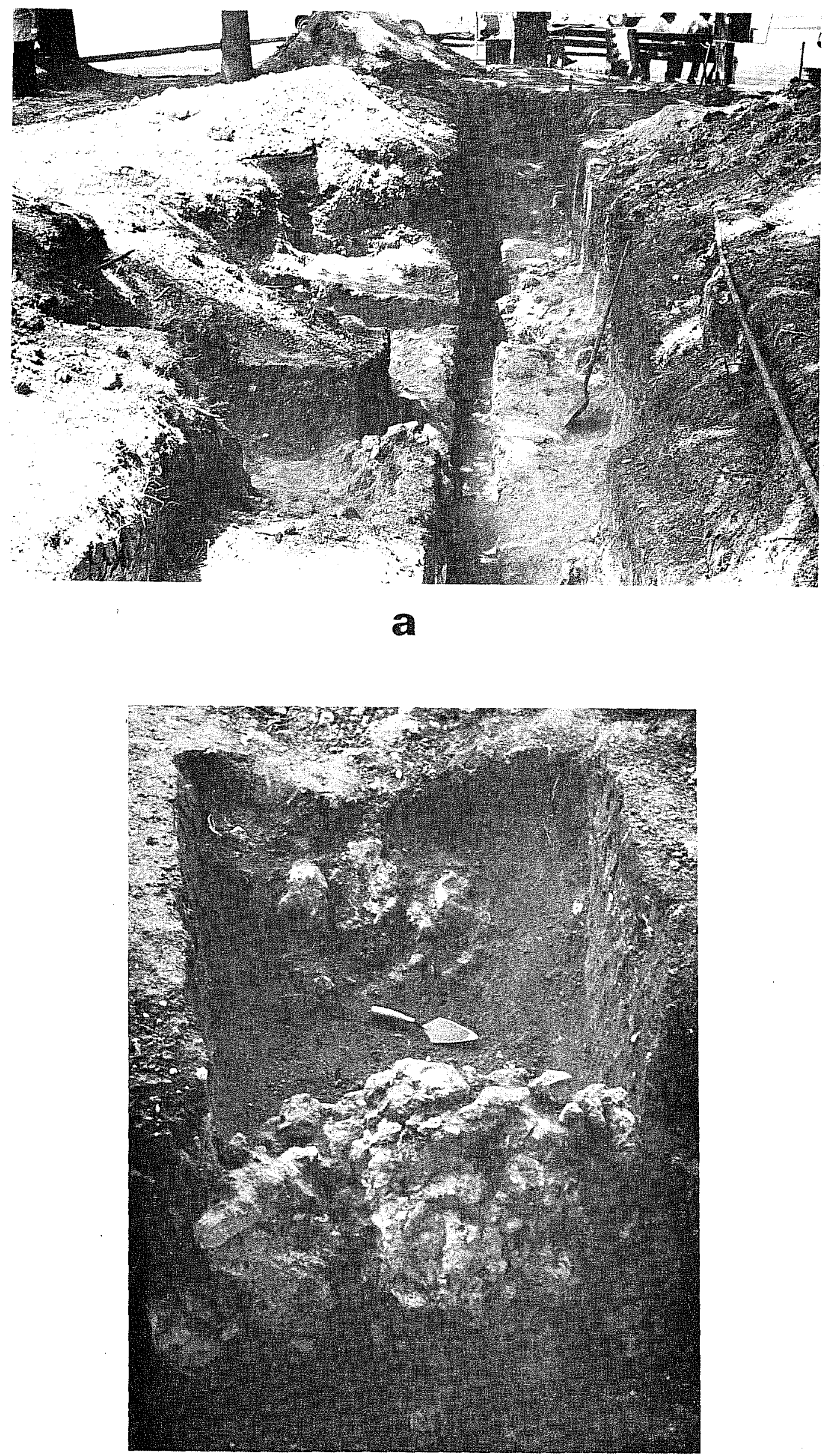

b 
structure, and where artifact-bearing strata might be found intact. At this point the soil thus removed was taken away by City trucks, leaving the park area clear for the archaeological excavation to begin. This same procedure was followed later in the project when it was determined that extensions of the original trenches would yield additional information.

Standard archaeological procedures were used throughout the project. With a few exceptions where such care was not warranted, soil was removed with trowel and shovel and screened through 1/4" wire mesh for maximum artifact recovery. Selected samples of matrix were taken for processing by flotation. Frequent checks were made of the midden soil at the south end of Trench $B$ by running samples through fine window screen to recover any trade beads or other minute artifacts that might be present.

A daily log, both in written form and on tape, was kept of all work done on the site. Detailed maps and profiles were made on a continuing basis of the trenches and of specific areas of interest within them. More than 350 color slides and black and white photographs were taken to document the project. All of these data are on file at the Center for Archaeological Research, UTSA.

Vertical control was maintained in relation to a datum point established at the base of a stake at the southeast corner of Trench A. Elevations of other secondary datum stakes were determined by use of a transit, and measurements are corrected in relation to the Trench $A$ datum. Specific individual elevations of features, profile base lines, etc., were also determined by transit, for cross-checking of measurements. Further control for reference in future excavations in the plaza has been assured by relating the elevation of the datum of the excavations to a specific point on the facade of the chapel (Fig. 13).

Horizontal control was maintained by use of a north-south base line established across the excavation area and designated as E100 meters. Stakes were established at one meter intervals where needed to insure accuracy in mapping individual features. Since excavation was limited to the two trenches, it was not deemed necessary to grid the entire area.

\section{Trench A}

This trench (Fig. 12; Fig. 14, a) as initially excavated by the backhoe measured approximately 1.25 meters wide and 16 meters in length. Primary backhoe excavation extended to an average depth of $70 \mathrm{~cm}$. There was a definite soil change at this point, from a black gumbo which contained late pottery sherds and bottle fragments to a brown clay with dark grey lenses containing a variety of late 19 th century ceramics, glass, and animal bone. 


\section{Figure 15. Profile of West wall, Trench A.}

Key to Stratification:

A. Dark grey clay with roots; no rocks

B. Brown clay with roots; scattered rocks and gravels

C. Compact dark grey clay

D. Grey midden soil with scattered rocks and charcoal

E. Dark tan compact granular soil

F. Light to dark tan granular soil mixed with limestone rubble

G. Loose $\tan$ fill

H. Yellowish calcareous friable clay with white inclusions 


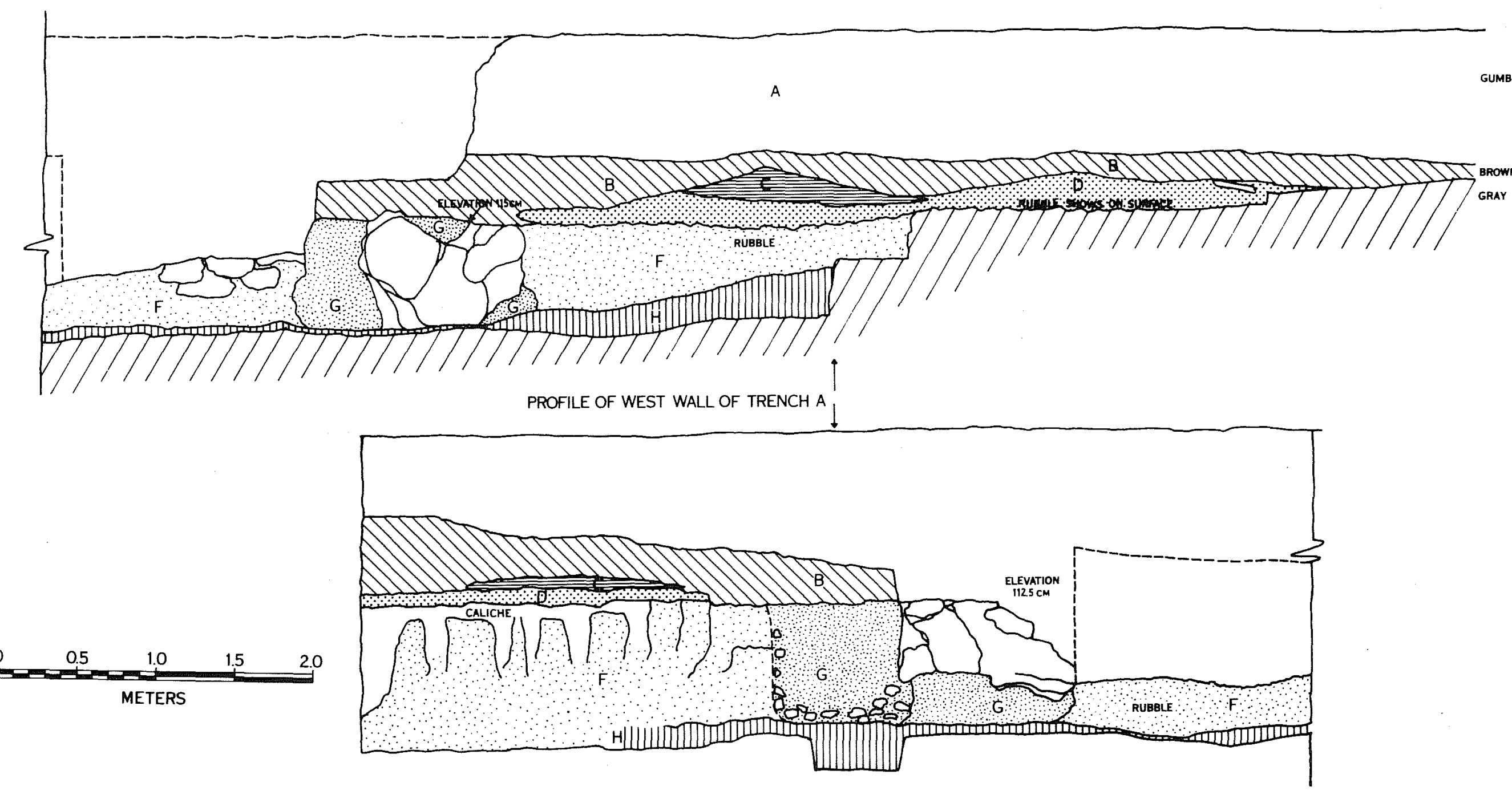


At the south end of Trench A a test pit one meter by four meters in size was excavated in $20 \mathrm{~cm}$ levels, and all soil removed was screened. At $125 \mathrm{~cm}$, a compact, sterile, caliche-like deposit was encountered. Further excavation of the northern half of this pit revealed that the same material continued to extend downward at $215 \mathrm{~cm}$. A grey-brown intrusion containing small river cobbles was exposed in the north end of the pit. At the north end of Trench A a layer of grey, ashy soil was exposed at $100 \mathrm{~cm}$ depth which contained 19 th century ceramics, glass, and bone.

When it became apparent that any remaining wall footings were deeper than the bottom of the present trench, the backhoe was used to remove another $50 \mathrm{~cm}$, this time locating solid rock in two separate locations, one at the north end of the test pit and another approximately six meters north of the first. After cleaning out and carefully examining the trench, it appeared that the footings for the south wall and the wall of the building inside it had been located (Fig. 14, b). The west side of the trench (Fig. 15) was enlarged to look for more wall indications, but, due to limitations in time and the problem of existing tree root systems and overburden, the results were inconclusive. Careful examination of an area directly west of the suspected south wall footing revealed dislocated chunks of consolidated stone within an area of brown, pebbly soil previously encountered in the north end of the test pit described above.

The entire area between the proposed wall footings was examined for traces of floors or other structures. Everything below the level of the present top of the footings was sterile, and the brown soil containing late 19th century artifacts carried across in an unbroken leve1 above.

In order to confirm the stratigraphy for comparative purposes, a small trench $30 \mathrm{~cm}$ wide was dug into the subsoil along the entire west profile of the trench. This bisected both wall footings, determining their maximum depth to be approximately $180 \mathrm{~cm}$ below datum.

At the south end of Trench A, a large mass of consolidated white limestone was examined to determine if it was related to the south wall. When the trench was extended to the south to examine the feature more closely, there was considerable discussion as to its possible origin. The top of the formation extends beyond the edges of the present trench to the east and west, and possibly to the south, at the $115 \mathrm{~cm}$ level. The rock extends downward to fade into yellow caliche subsoil at about $190 \mathrm{~cm}$, with no visible line of demarcation.

\section{Trenches $B$ and $C$}

Initial backhoe excavation was carried to a depth of $80 \mathrm{~cm}$, clearing a trench 1.25 meters wide and 12 meters long, and revealing stratification similar to that in Trench A (Fig. 12; Figs. 16, 17, 18). An 
Figure 16. Profile of East Wall, Trench B. For key to stratigraphic designations, see page 41. 
Figure 17. Profile of South End, Trench B. For key to stratigraphic designations, see page 41. Cross section of fortification ditch can be seen at left center. 


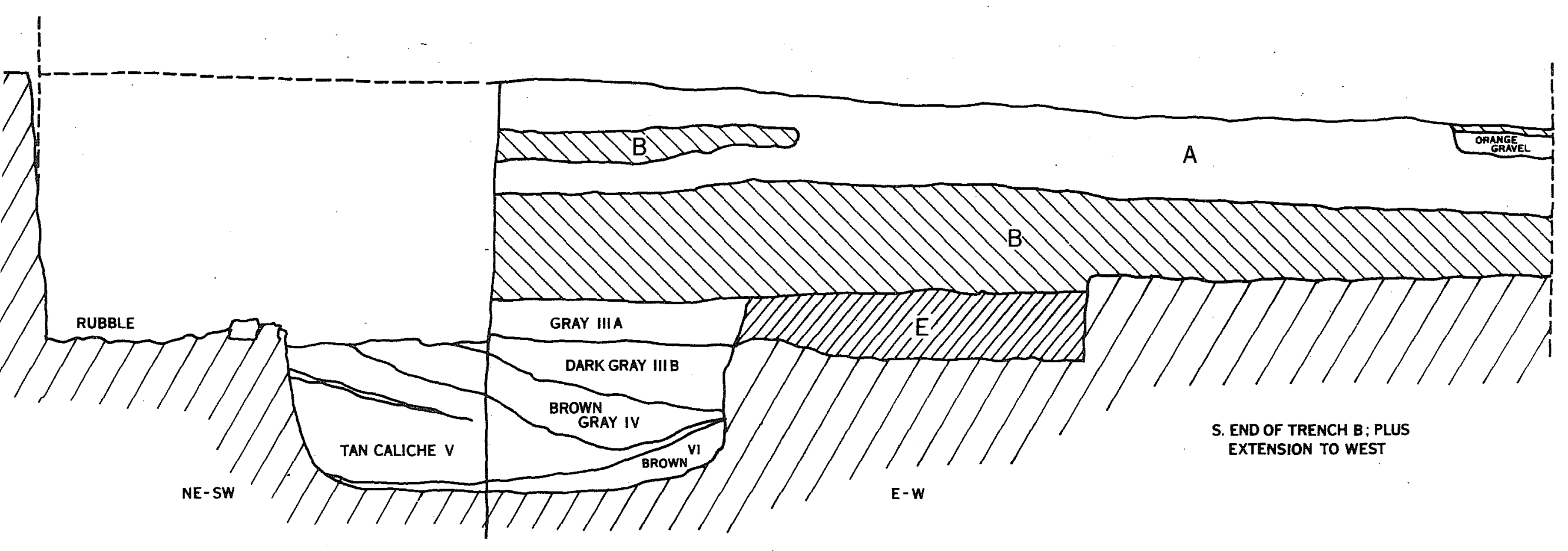

$\begin{array}{llll}0.5 & 1.0 & 1.5 & 2.0 \\ \text { METERS } & 0.5\end{array}$


additional $10 \mathrm{~cm}$ of excavation through a grey, artifact-laden stratum, containing artifacts dating from the late 18 th to the mid-19th centuries, revealed a rather compact level made up of medium-sized stones surrounded by friable tan soil. At first it appeared that these stones might be the remains of a wall or a pavement, but it soon was observed that they extended over most of the site at this level and may be a natural part of the subsoil. A small shovel test near the center of the trench revealed that the brown soil graded into a sterile, yellow caliche which extended to at least $170 \mathrm{~cm}$, resembling the stratification revealed in the test pit at the south end of Trench A.

Trench $C$ was then excavated west to the sidewalk from Trench $B$ in an attempt to discover the delineation of a feature which began to appear at the north end of Trench $B$ as a line beyond which the stones did not extend. A $90 \mathrm{~cm}$ wide ditch was uncovered which ran in a straight line north to south across both trenches and was apparently dug through the grey and the rubble strata from the brown level above. This ditch, which is filled with white caliche, extended south briefly into the west extension of Trench $B$ at the south end and appeared to be rising at a rate of eight $\mathrm{cm}$ per meter from north to south. The origin and purpose of this feature have not as yet been ascertained, but it may have been connected with park construction in the late 19th century.

No other features were found in the north and central portions of Trench B. However, at the south end another possible wall footing containing large rocks was located approximately 2.5 meters north of the south end of the trench.

Just south of this feature, an area of light grey midden soil was uncovered (at $140 \mathrm{~cm}$ ) which differed from the grey level previously encountered in that it contained mission period artifacts almost exclusively. Additionally it had a sharp line of demarcation along the north and west sides, indicating that it was dug through the surrounding rubble-filled level. After cleaning the south end of the trench carefully to the $155 \mathrm{~cm}$ level, a definite pattern of various shades of grey was apparent on the surface. At this point, the surface was mapped and the various zones were numbered I, II, etc., and removed separately. It was apparent as this process continued that the zones lay diagonally one over another varying in depth and angle much as if discrete loads had been thrown into a trench. When the bottom of the feature was discovered at $205 \mathrm{~cm}$, it was found to have a somewhat rounded contour, with straight-cut sides above (Figs. 17, 18, b). Trench B was extended to the south and east for further investigation of this feature and of the possible wall footing. The zones were again identified and removed separately.

In clearing off the top of the rubble level toward the west at the south end of Trench B, it was observed that the stones ceased at an 
Figure 18. Excavations in Alamo Plaza, 1975. a, view looking northeast from west side of Trench $B$, showing relationship of excavation to chapel and stratification in east profile of Trench $B$; $b$, view looking south into the end of Trench $B$, showing shape of excavated portion of fortification ditch and profile of fill. 


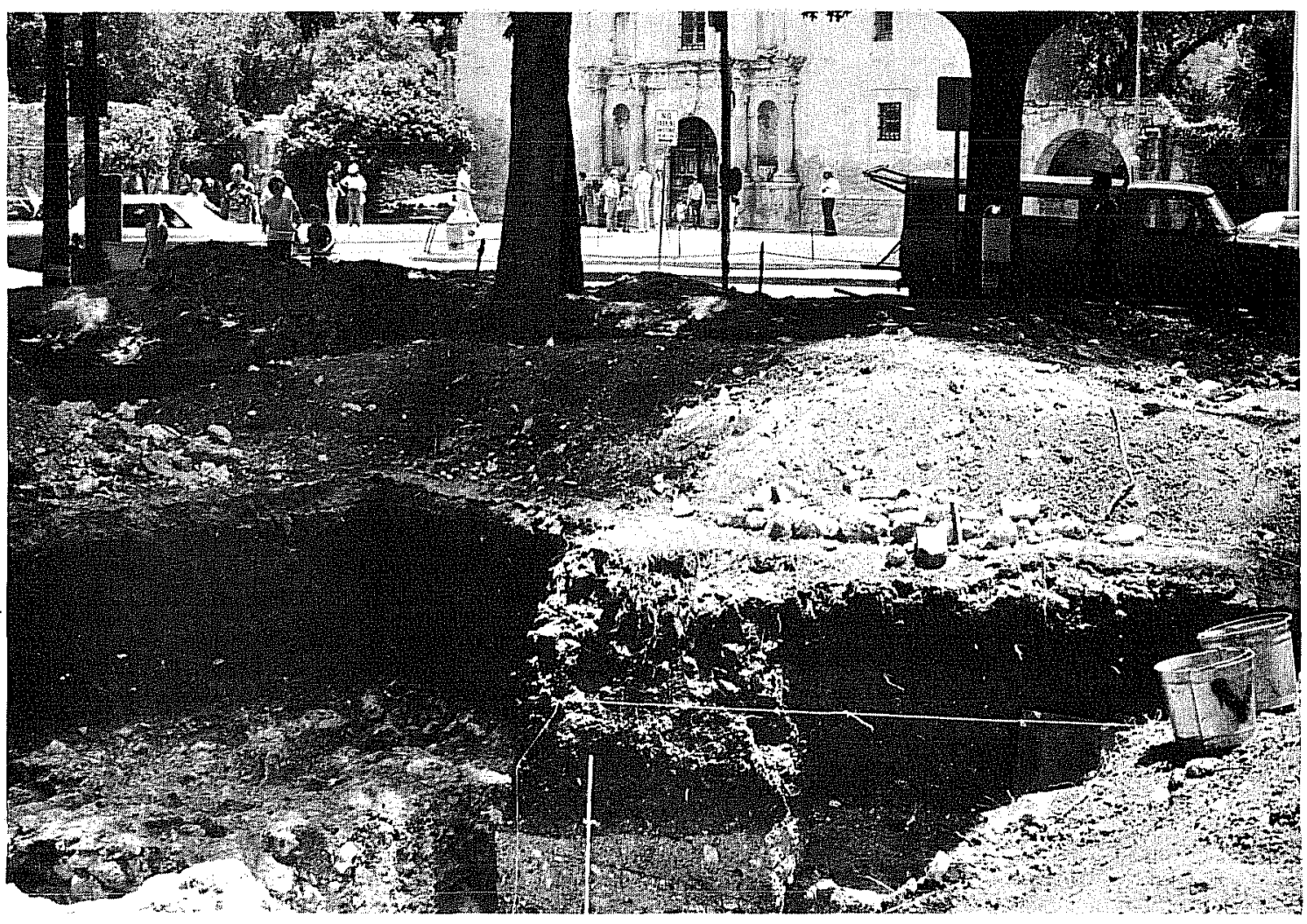

2)

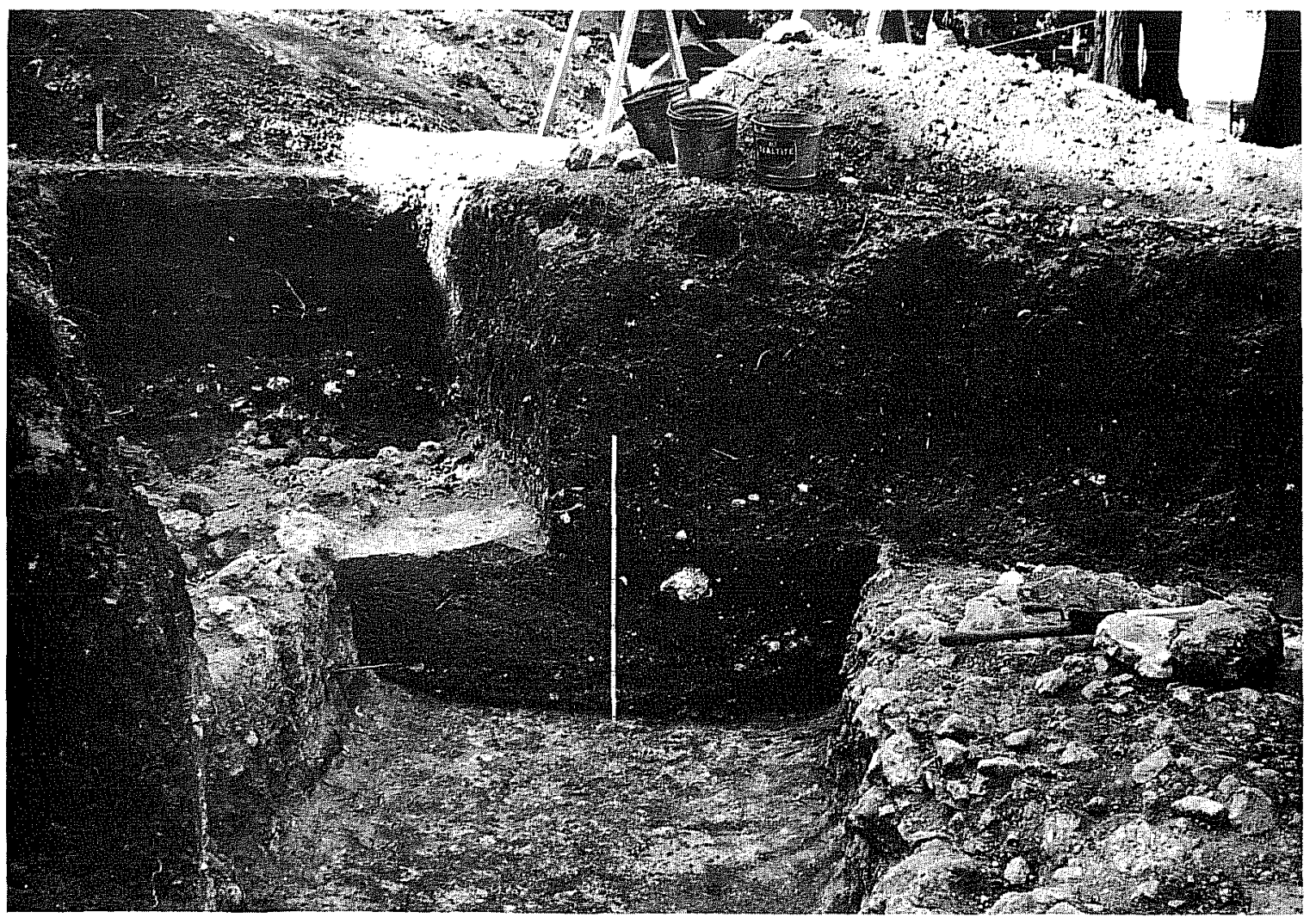


east-west line just north of the edge of the excavation (Fig. 12). Time did not allow further investigation to determine the reason for this change.

\section{Discussion of Features}

Although many maps have been drawn of the compound of Mission San Antonio de Valero, the two most dependable, given the training of the artist and reasons for the execution of the map, were done by Francois Giraud, City Engineer and architect for Samuel Maverick in 1849, (Fig. 5) and by Theodore Gentilz, artist and architect, as background study for a painting probably in 1849 or 1850 (Gentilz n.d.). These agree rather closely in the important details, and have been extensive$1 y$ used on this project in evaluating the architectural remains uncovered (Fig. 11).

In Trench A two intrusive masses of rubble consisting of large irregular chunks of limestone set in a grey-brown, pebbly soil, were encountered at approximately $115 \mathrm{~cm}$ depth (Fig. 14, b). The southernmost one measures $190 \mathrm{~cm}$ across and extends downward to a level of $186 \mathrm{~cm}$. The northern one measures 135 to $140 \mathrm{~cm}$ across and extends to $180 \mathrm{~cm}$. The distance between the outside faces of these features is approximately 615 meters ( 17 feet). The location of these features in relation to the buildings still standing and in relation to wall locations on the maps of Giraud and Gentilz, plus the fact that they are unquestionably intrusions into the subsoil, lead to the conclusion that these are the footings of the south wall and the building constructed within it.

In Trench $B$, near the south end, a smaller intrusion of limestone chunks surrounded by friable, brown soil (Fig. 16) may be the continuation of the south wall footing to the west, toward the gate. If this is so, Giraud's map may sot hava been completely accurate in the angle of this wall, either by accident of drafting or of measurement. It is interesting to speculate upon the effect which alteration of this angle by a few degrees could have on the location of the northwest corner of the mission, which falls within the former property of Samuel Maverick, for whom the map was drawn.

The absence of a definite $F$,oting to the north in Trench $B$ can be explained by the amount of earth-moving which has been done in the area since 1870. There is evidence of disturbance of the subsoil in the general area where it should lie, however (Fig. 16). The fact that the Gentilz and Giraud maps are so close to agreement on the angle of the wall makes it seem likely that the stone found in Trench B was slightly displaced during later clearing activities. Certainly it is not sufficient evidence to suggest any drastic revision of the present estimate of the locations of the walls.

It appears from archaeological evidence that considerable earth moving and levelling was done on the plaza in the late 19th century. Apparently, the grade was lowered below the level of the floors and base of 
the walls of the buildings on the south wall, since no trace of floors was found in either trench and no recognizable building stone or mortar debris above the footings still remains. The grey layer which intermittently covers the site is evidently all that remains of the original floors and plaza surface, which was scraped and churned up and redeposited during the levelling process. The brown soil containing middle-to-late 19 th century artifacts was then probably hauled in from elsewhere to create the park, and was later covered with black gumbo during landscaping operations.

The ditch at the south end of Trench B (Fig. 12) appears to be part of the fortification of the gate, illustrated variously on the maps of Potter (Chabot 1931: 75), Berlandier (Chabot 1931: 59) and a composite map of those done by participating Mexican officers (Santos 1968: 164). No two observers agree exactly on the size, shape and location of a ditch and parapet arrangement within which were mounted two or three cannon for protection of the gateway. The location of the ditch appears quite far from the actual gate until one realizes that there must be room behind it for a parapet, behind which the cannon required at least double their length to allow for the recoil on firing, and behind this there must be enough room to pass through the gate.

Apparently the ditch was dug carefully (the walls are straight and uniform) and may have been refilled not too long after the battle, since pick marks are still visible in the west wall. The fact that fragments of several objects were found to occur in several different zones in the fill suggests that this material accumulated in a pile somewhere nearby and was dug up and redeposited in the ditch on a single occasion. The location of a wine glass (Fig. 23, b) manufactured before 1830 (Noël Hume 1970: 190-191 and 1975) within Zone VI made it appear, on first examination, that the ditch was filled soon after the 1836 battle. However, the presence of two later artifacts elsewhere in the fill suggest a later date for the operation. A metal button (Fig. 25, g) of a type found by South (1964: 122) in Florida in an 1837 to 1865 context and a percussion cap (Fig. 25, f) which probably would not have arrived in Texas until after 1840 (John Clark and Sam Nesmith, personal communication) suggest that the ditch may have been filled by U.S. troops when the Army restored the south wall structure in 1848-1849 (Brown 1892: 572).

The importance of the fill, however, is that its contents indicate there was a Spanish colonial mission trash dump somewhere in the vicinity. Such dumps are known to exist outside of gates of mission establishments of this period, including both San Juan Capistrano (Schuetz 1968: Fig. 19) and San José (Schuetz 1970: 8). This suggests that the south wall and main gate of the mission could have been located here from at least the mid-18th century, if not before.

One explanation which came to mind for the hurried refilling of the ditch is possible use as a burial pit for Mexican casualties after the 1836 battle. A careful watch was kept during excavation, but no 
indications were found of such usage. However, this does not mean that there may not be burials elsewhere in the section of the ditch which is as yet unexamined.

\section{Artifacts}

In general, artifacts are ordered according to the material from which they are made, avoiding where possible categories such as Indian, Spanish, Colonial, or grouping according to use. In many cases origins and/or uses are not definitely known, and such groupings would reflect a purely subjective decision on the part of the author. The majority of the artifacts found in the ditch are identical to or closely related to ones found in other Texas mission sites, or are known to have been made in the 18th century and are therefore probably mission-connected. Sources for this information include published excavation reports for missions San Juan Capistrano (Schuetz 1969), San José y San Miguel de Aguayo (Schuetz 1970), Rosario (Gilmore 1974), Valero (Greer 1967), the San Xavier missions (Gilmore 1969), and Presidio Ahumada (Tunnel1 1969), as well as the author's personal observation of collections from numerous other Spanish colonial sites in Texas and Northeastern Mexico.

The columns at the right side of each page indicate the number of fragments or objects found in the grey stratum which overlay the early footings, and those found in the fortification ditch. A description of more precise location within the ditch will be found in Table 1. An inventory of artifacts recovered from the park fill is included as Appendix 1.

Identification and dating of the artifacts has been done with as much care and precision as possible, and the author of this section takes fu11 responsibility for any inadvertent errors. 
Used universally as a dependable dating tool, the ubiquitous, nearly-indestructible potsherd rates first in order of artifact descriptions. In this excavation many fragments were so small as to make identification difficult to impossible. Where questions exist, general rather than specific categories are used. Numbers refer to sherds, not individual vessels.

\section{Porcelain}

Cup and saucer or plate. White, undecorated.

Unidentified; could be French, late 19th century.

Marble, $14 \mathrm{~mm}$ diameter. White, unglazed. Similar to others found on late 19 th century sites (Roberson 1974: 51).

\section{Stoneware}

Bottle or jug, $15 \mathrm{~cm}$ body diameter. Grey paste, salt glaze outside, tan slip instde. Late 19th century, U.S.

Bottle, 8-9 cm body diameter. Light tan paste with Bristol glaze. Ginger beer, probably Scottish (Emslie 1957), 1860-1900 in Texas.

\section{Earthenware, hardpaste}

The primary souces for dates of manufacture of English earthenwares have been Stanley South's "Ceramic Analysis Tools for the Interpretation of 18th Century British American Sites" (1972: 85) and Noë1 Hume's Artifacts of Colonial America (1970). It is interesting to note the presence of English wares in what is clearly a middle to late 18th century Spanish colonial context in the fortification ditch, despite Spanish laws against importation of English wares at that time. A vessel or two of these wares is frequently represented in mid-18th century Spanish sites across the southwest, reflecting the extensive contraband trade going on during the Colonial Period (Gibson 1966: 173). The official opening of New Spain to English trade by the Spanish Crown after 
1789 (Hussey 1963: 329) increased the flow which by 1840 became a flood of English earthenwares directly to the Texas settlements as well as to Mexico (Cervantes 1975: 50).

Straight-sided jar ca. $15 \mathrm{~cm}$ diameter. Cream paste, clear glaze give yellow appearance. Late 19 th century.

Bow1. Cream paste, clear glaze, blue and white decoration under glaze, would have had dendritic Mocha design in a band around the outside. England and America, late 19th-early 20th century (Noë1 Hume 1970: 131).

Unidentified vessel. White paste, bright yellow glaze.

Mugs and bowls. (Fig. 19, d-f) White paste, clear

glaze, bands, dendritic and molded designs, in blues, browns and white. Mocha or annular ware, England (Noë1 Hume 1970: 131-132; Schuetz 1969: 16-18; McClinton 1951: 1-7) 1790-1890.

Plates and bowls. (Fig. 19, j-k) White paste, clear glaze, transfer patterns in blue. England, 1790-1840.

Cups and deep saucers or plates. (Fig. 19, b, c,i) White paste, clear glaze, handpainted underglaze polychrome floral designs, in shades of green, red, blue, black. England (McClinton 1951: 30; Schuetz 1969: 11-12) 1820-1840, carried over to $1850^{\prime} \mathrm{s}$ in Texas.

Deep saucer ca. $15 \mathrm{~cm}$ diameter. (Fig. 19, a) White paste, clear glaze, underglaze blue floral design. England, 1780-1820 (Schuetz 1969: 12).

Plate and bow1. (Fig. 19, h) White paste, clear glaze, blue sponged or spattered decoration under clear glaze. England ca. 1790-1840 (Greaser and Greaser 1964: 5) found up to Civil War in Texas.

Cap ca. $10 \mathrm{~cm}$ diameter. (Fig. 19, g) White paste, clear glaze, green band under rim, red cut-sponge design. England or Scotland, early to mid-19th century (Greaser and Greaser 1964: 103-104) found up to Civil War in Texas. 
Figure 19. Artifacts from Alamo Plaza. a, blue hand-painted floral design; $b$, pale green, rose and black hand-painted design; c, yellow, green and brown hand-painted floral design; $d$, annular ware - dark brown on cream; e, mocha - dark brown and tan bands, green impressed design; $f$, mocha - brown with dark brown or black dendritic design; g, green band, red cutsponge design; $h$, blue sponged decoration; $i$, dark green and pink hand-painted design, late 19th century pattern; $j$, transfer design in bright blue, late 19 th century pattern; $k$, transfer design in dark blue-grey; 1 , blue painted-over molded she11 design; m, U.S. five cent piece, shield type, 1867-1883. 


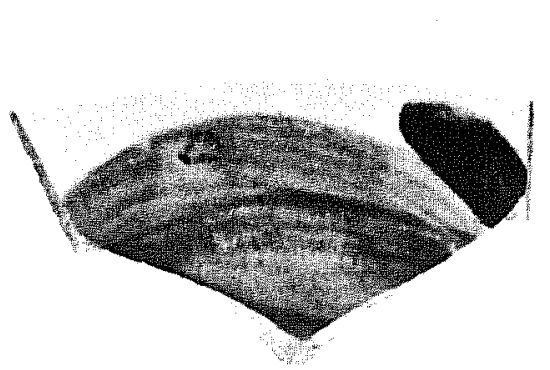

a
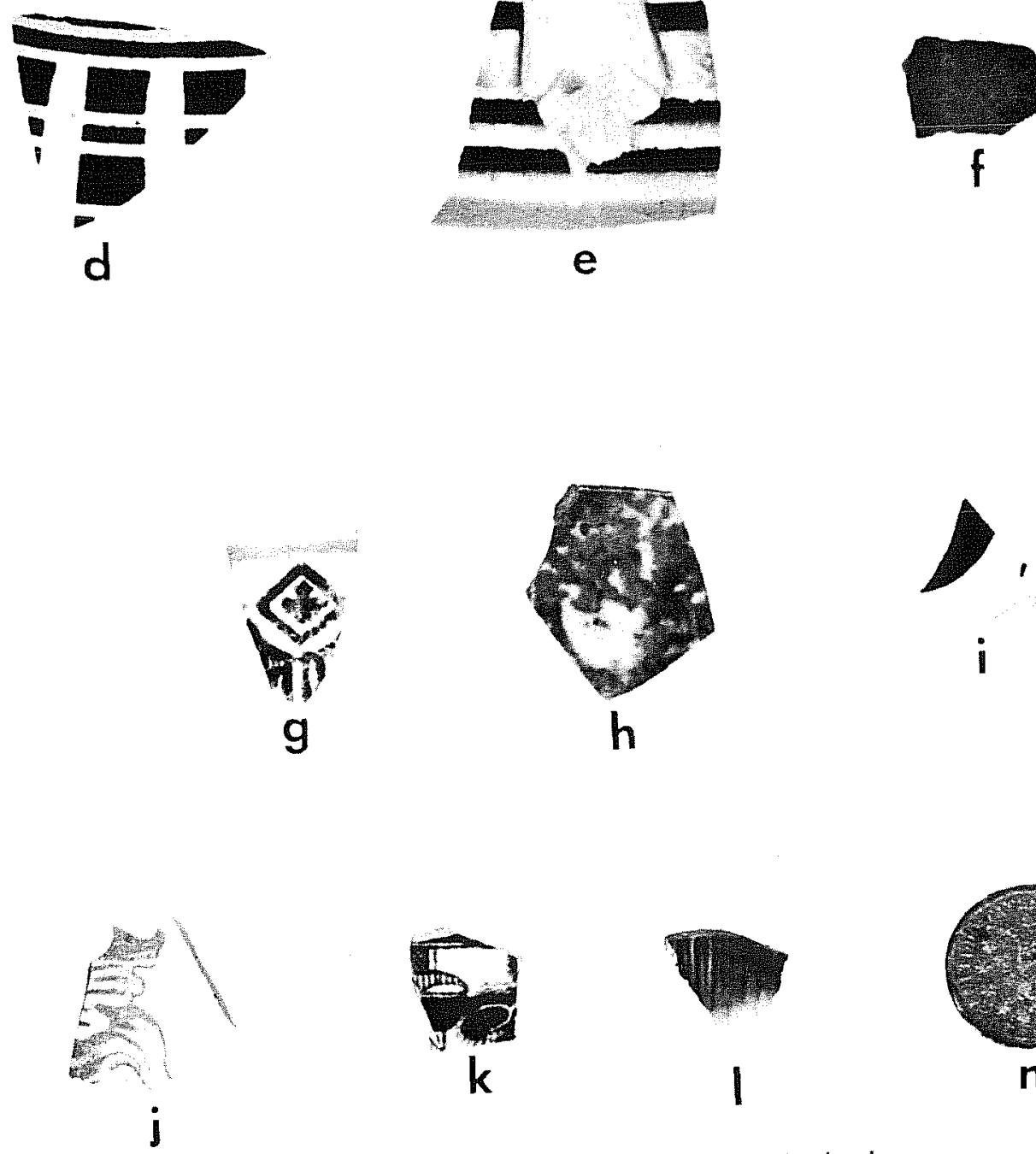

$\mathrm{cm} \mid$\begin{tabular}{ll|l|l|l|l}
1 & 1 & 1 & 1 & 1 \\
& 2 & 3 & 4 & 5
\end{tabular}
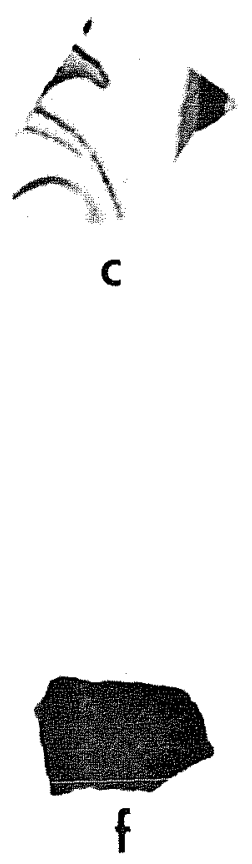

e

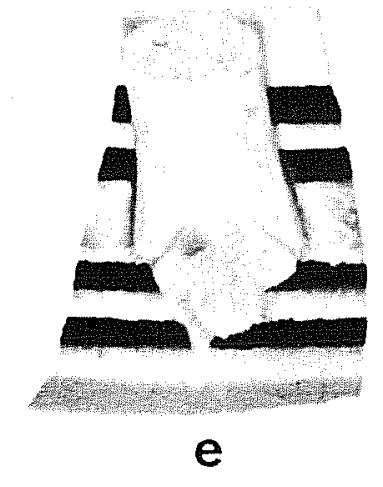

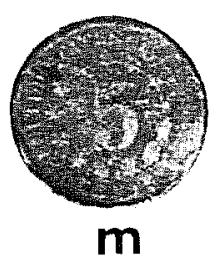


Grey

Stratum

1

Plates. (Fig. 19, 1) White paste, blue molded edge under clear glaze. Shel1-edged ware (Noë1

Hume 1970: 131) 1780-1830.

Bowl and plates. White paste, undecorated, clear glaze. Some are undecorated portions of vessels above. Pearl ware and cream ware (Noël Hume 1970: 130) $1762-1830$.

Heavy plates, footed vessels. White paste, undecorated, clear glaze. Semfporcelain (Noë1 Hume 1970: 130-131) England or U.S., generally found in Texas after 1850 .

Pipe. Orange paste, clear glaze, impressed anthropomorphic design. Late 19 th century (Thomas and Burnett 1972: 20-22; Schuetz 1969: Plate 19).

Pipe. Dark grey paste, thin lead glaze, trace of impressed design just under rim. May be locally made.

\section{Earthenware, softpaste}

Unidentified vessel. White paste, opaque green glaze one side, mottled lavender and blue-green on the other. Resembles Victorian Majolica, 1850-1900 (McClinton 1951: 31).

Straight sided vessels ca. $19 \mathrm{~cm}$ diameter. Cream paste, unglazed. Resemble flower pots. Probably late 19 th century.

\section{Majolica}

The sources for identification and dating in this section are Goggin's Spanish Majolica in the New world (1968) and Barnes and May's Mexican Majolica in Northern New Spain (1972). Categories are limited to the general "style" as the term is defined by Barnes and May (page 6), more detailed analysis being impossible due to the small size and number of sherds recovered.

Bow1. Cream paste, white background, blue band 
Figure 20. Artifacts from Alamo Plaza. a, Majolica green, tan and yellow floral design, pinkish tan paste; b, Majolica - green design on greenish-cream background, pinkish tan paste; c, Majolica - grey-blue floral design, tan paste; d, Majolica - light and dark blue floral designs accented with black, cream paste; e, Faience - blue-tinted enamel on pink paste; $f$, unidentified ware - tan and brown design on buff background, red paste; $g$, medicine bottle - aquamarine, handblown; h, pressed glass fragment, pale blue; $i$, medicine bottle - turquoise, octagonal base, pontil. 

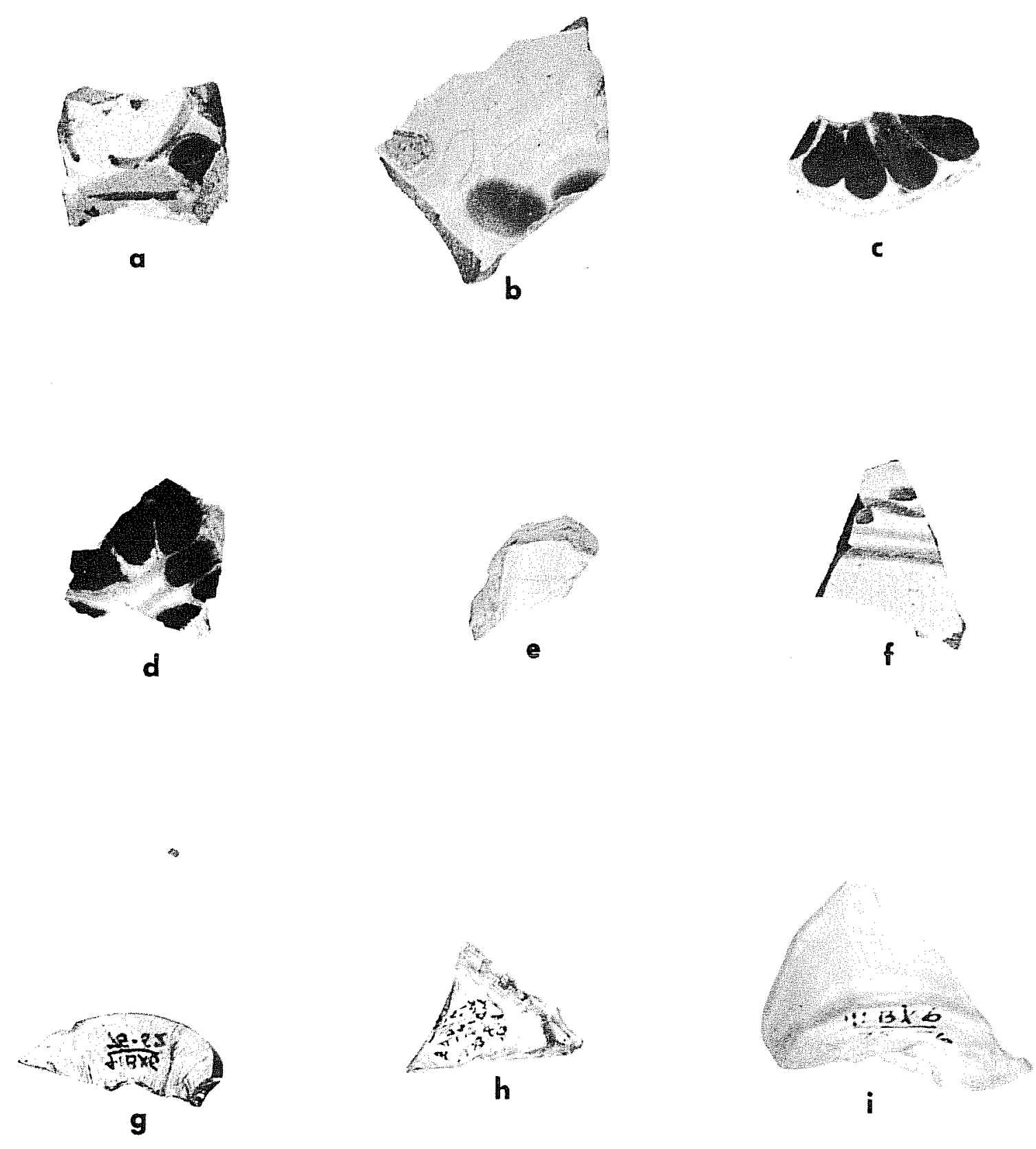

$\mathrm{cm}\left|\begin{array}{llll|l|l|l}1 & 1 & 1 & 1 & 1 & 1 & 1 \\ 1 & 2 & 3 & 4 & 5\end{array}\right|$ 
Plates and cup. (Fig. 20, c) Pinkish tan paste white background, blue floral design. Puebla Blue on White, 1700-1850.

Plates. (Fig.20, d) Cream paste, white background, blue floral designs accented with black. San Augustine Blue on White, 1700-1750.

Plate and cup. (Fig. 20, a, b) Pinkish tan paste, white background, green, yellow, gold, brown floral designs. Aranama Tradition (Barnes and May 1972: $34), 1750-1850$.

Unidentified fragment. Red paste, white background, blue band over 1ip. Too sma11 to identify.

Plates. Cream to pinkish tan paste, white to cream ename1, undecorated. Some are part of decorated vessels, some could be Unclassified White as described by Goggin (1968: 201-202).

Faience

Plate. (Fig. 20, e) Pink paste, white tin enamel with bluish tint (Tunnell and Ambler 1967: 33-35).

Unidentified tin enameled ware

Bottle neck. Cream paste, cream tin ename1 on outside, unglazed on inside.

Plate. (Fig. 20, f) Red paste, buff tin ename1 background, over-glaze painted design in shades of brown. Paste resembles late Majolica, design resembles Faience, technique of decoration looks French.

\section{Mexican earthenwares}

The basic source for identification and dating in this section is a study of such wares currently being done by Anne A. Fox, a preliminary summary of which appears in Fox (1974: 55-60). 
Figure 21. Artifacts from Alamo Plaza. a, o1la red-brown slip band over lip, tan paste; b, burnished red-brown slip on grey paste; c, burnished designs on red paste; $d$, brown band over rim, orange paste; e, green over cream designs, orange paste; $f$, green and red-brown floral design over cream slip, orange to grey paste; $g$, greenish brown glaze, red paste; h, unglazed, red-painted band around rim, orange to grey paste; $i$, yellow glaze, orange sandy paste; $j$, unglazed, tan interior, brown to black exterior, grey paste with bone temper;

$k$, unglazed, red painted band, orange to grey paste. 

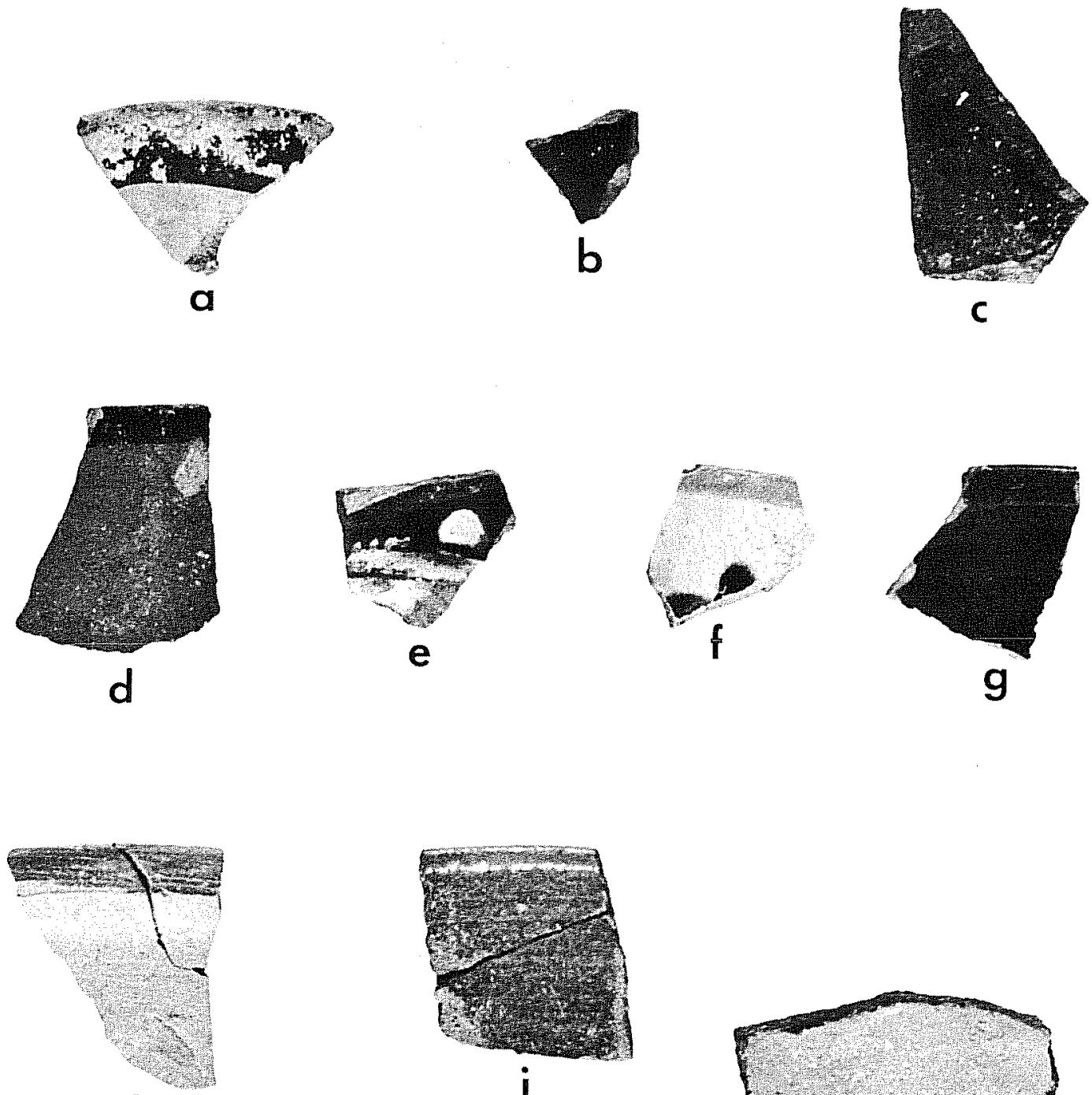

h
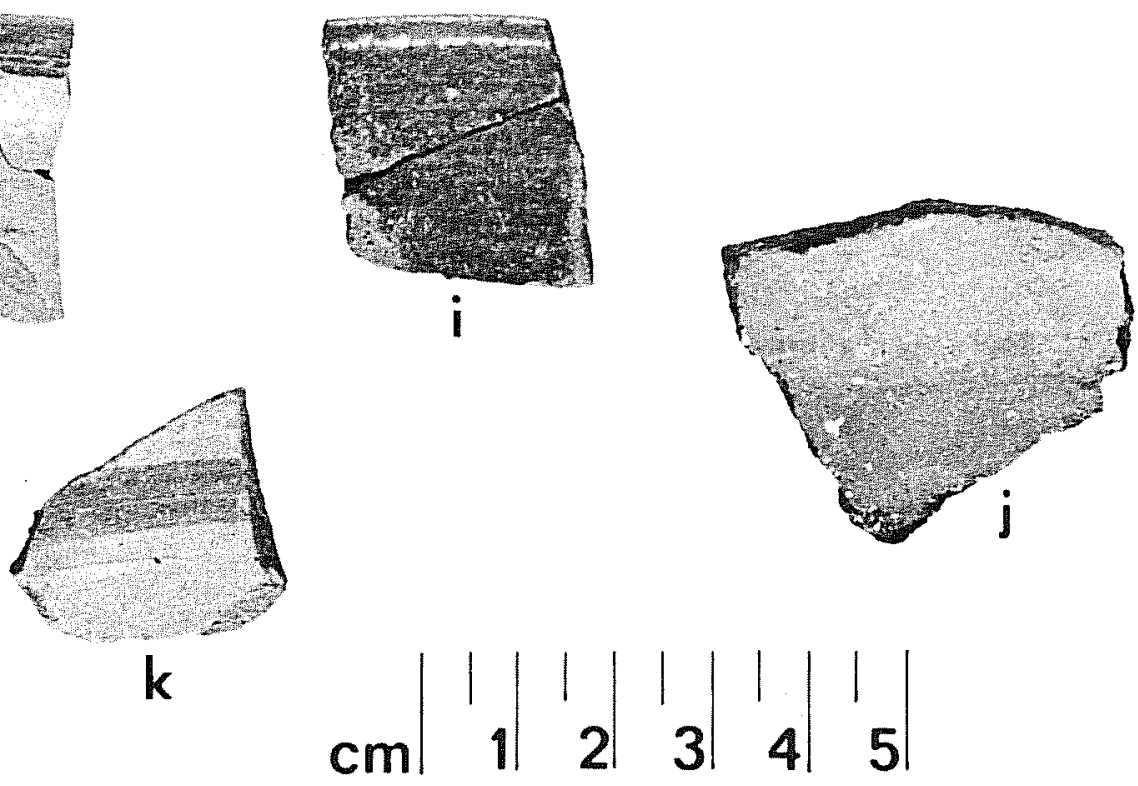
Little is known as yet about the places of manufacture of these wares, but the sophistication of their construction and design point to an origin in the pottery centers of Mexico. They appear in varied assortments, sometimes only a sherd or two at a time, in most Spanish sites in Texas. Dating of these wares appears to extend from the first quarter of the 18th century past the turn of the 19 th century. Some similar types are still being made.

Heavy bowls. (Fig. 21, i) Orange to grey sandy paste, clear lead glaze shading to greenish tint. Sandy Paste Utility Ware (Fox 1974: 56-57), also called Mexican Lead Glazed Ware (Schuetz 1969: 52-54).

Thin plates and jars. (Fig. 21, d, e; Fig. 22, a, b) Orange to grey paste, clear lead glaze, brown, cream, and green designs. Decorated Orange Ware (Fox 1974: 57-58), also West Mexico Polychrome (Schuetz 1969: 50-51).

Plate. (Fig. 21, f) Orange to grey paste, cream slip with green and red-brown floral design under a yellowish lead glaze, green band over rim. Possibly Tonala Ware (Jalisco) (Barnes 1974).

Bow1. Orange to grey paste, lead glaze, impressed design. Decorated Orange Ware (Fox 1974: 58), also West Mexico Polychrome (Schuetz 1969: 50).

Plate. (Fig. 21, g) Red paste, greenish-brown lead 19 55 glaze, thicker on inside of vessel. Resembles RedBrown Ware (Fox 1974: 59), also Guadalajara Ware (Schuetz 1969: 51) except for greenish tinge to glaze.

Bowls. (Fig. 21, c) Red paste, burnished surface with matte designs. Red Burnished (Gilmore 1974: 63); also Mexican Burnished Red (Schuetz 1969: 52).

Unidentified vesse1. (Fig. 21, b) Grey paste, burnished red slip on one side only. Red Burnished S1ip Ware (Gilmore 1974: 63).

011a rim. (Fig. 21, a) ca. $7 \mathrm{~cm}$ diameter. Tan paste, red-brown burnished slip in band over rim. Polychrome Burnished (Gilmore 1974: 63), also Mexican Slip Painted Ware (Schuetz 1969: 52). 
Figure 22. Ceramic Vessel from Alamo Plaza. a, b, two views (restored). Jar or pitcher, one handle. Height, $12.5 \mathrm{~cm}$; diameter at mouth, $9.5 \mathrm{~cm}$; diameter at shoulder, $13 \mathrm{~cm}$. Green-over-cream band around rim, cream dots, orange paste. 

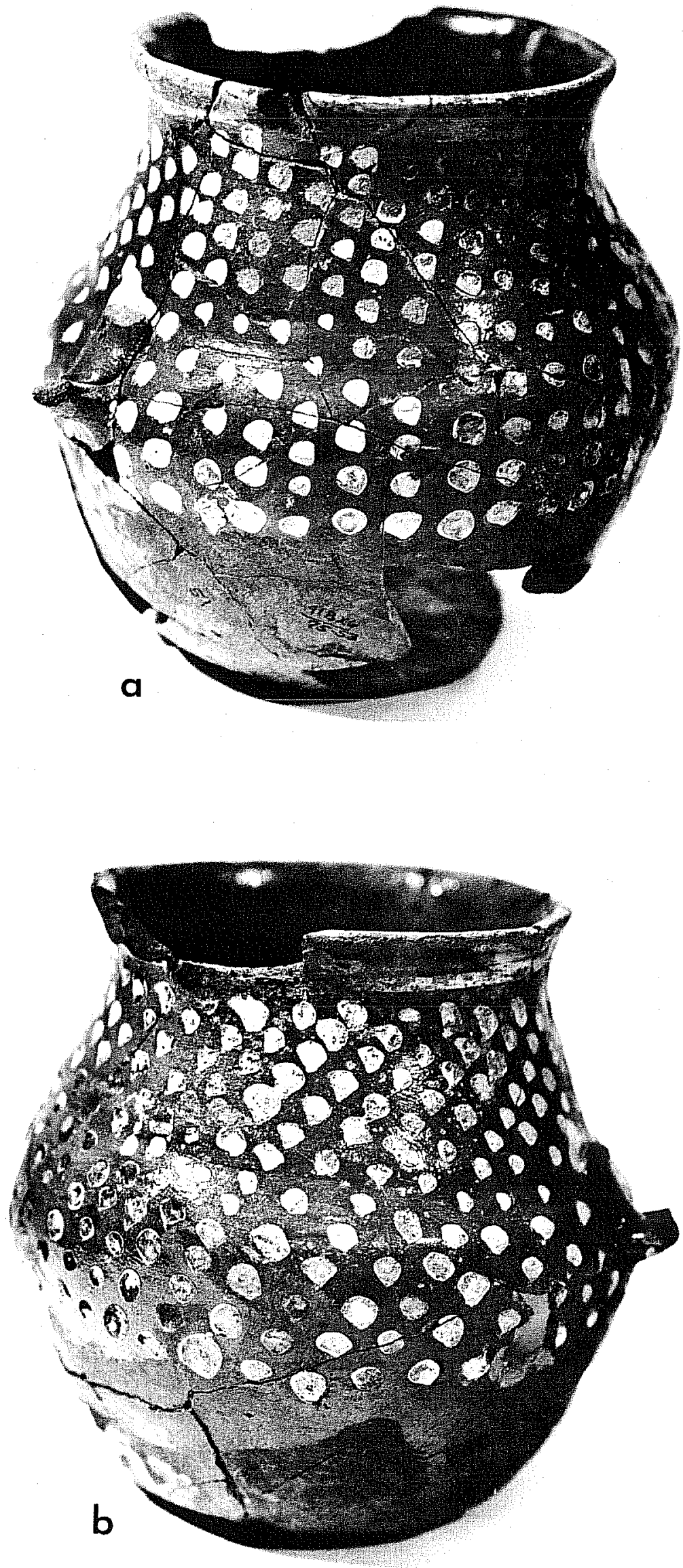
Heavy plates and bowls, average 9 - $10 \mathrm{~mm}$ thick.

(Fig. 21, h, k) Orange to grey paste, unglazed, occasionally have red-painted band around rim or in bottom of plate. May correspond to Greer's Red-on-orange (1967: 19). The proportionately large number of sherds of this type suggest the possibility that it was being made locally, perhaps a tradition brought here by early settlers from Mexico. This is the only wheel-made pottery appearing in sufficient amounts to suggest local manufacture.

\section{Indian-made earthenware}

These bone-tempered sherds are of the type designated Goliad ware by Mounger (1959). This type is found on Spanish sites in central and south Texas in conjunction, as in this case, with Indian-made artifacts of bone, shell and stone as well as with Spanish imported objects and ceramics. The close resemblance to the Leon Plain ware attributed to Neo-American peoples of central (Suhm and Jelks 1962: 95) and south Texas (Hester 1968: 11; Hester and Hill 1971) is interesting in its implication that Goliad ware may be an out-growth of the Leon Plain tradition. Further studies of both types must be made before any conclusions of this sort are possible.

Bowls and ollas. (Fig. 21, j) Shades of red through orange to grey paste, bone-tempered. Goliad ware (Mounger 1959).

\section{GLASS}

On the whole, fragments are too small to allow determination of vessel shapes or sizes, and no dating clues were present in the form of necks or bases, except in the cases noted.

Dark green (black glass) wine bottle fragments.

01ive green wine bottle fragments.

Olive green wine bottle, fragments of one bottle

(Fig. 23, a). Pontil, deep kick-up, sheared 1ip, ca. 1810-1840 (Newman 1970: 73). 
Figure 23. Artifacts from Alamo Plaza. a, olive green wine bottle, deep kick-up, pontil; b, clear cut-glass stemmed drinking glass, ground pontil. 

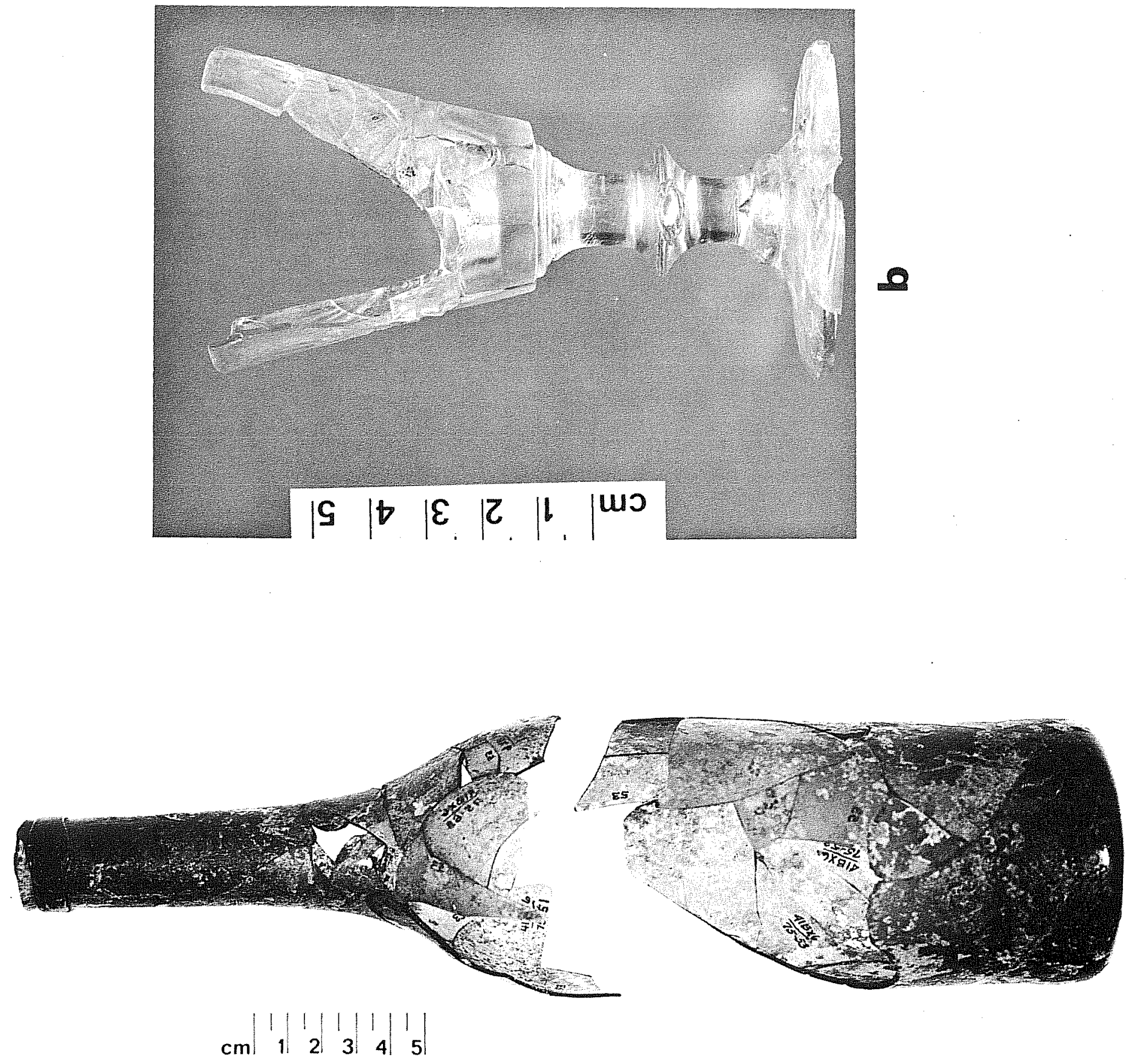
Turquoise medicine bottle base, (Fig. 20, i).

Bottom diameter, $3 \mathrm{~cm}$; pont11, faceted sides, identical bottle in collection of Dr. Sam Greer of San Antonio, mid-19th century.

Aquamarine medicine bottle fragments. (FIg. 20, g) probably late 18th century (Noël Hume 1970: 74).

Turquoise sun-colored medicine and soda water

bottle fragments, stopper fragment.

Pale blue pressed glass fragment, (Fig. 20, h)

mid-19th century (McClinton 1951: 145).

Pink glass fragment.

Milk glass fragment.

1

Clear glass bottle fragments.

Thin, clear lamp chimney fragments.

9

Frosted fragment with impressed design.

Clear, cut-glass stemmed drinking glass, (Fig. 23,

b) ; $9.2 \mathrm{~cm}$ high, ground pont11. 1815-1830.

(Noë1 Hume 1969: 190 and FIg. 64, XXV).

Flat glass, mirror or window, $2 \mathrm{~mm}$ thick.

Bead, small (3 mm) dark Bluebird Blue, translucent donut-shaped garter bead of simple construction, tumbled. 1700-1836 (Harris and Harris 1967: 144, No. 48).

Milk glass button, 4 holes, $11 \mathrm{~mm}$ diameter. Typical of late 19 th - early 20 th century.

\section{SHELL}

Mussel shell fragments were present in every zone of the ditch excavation, whereas they were only occasionally found in other areas. Beads similar to the ones found here (Fig. 24, e-h) have been reported from other sites in south Texas (Thomas Hester, personal notes). A burial now in storage at the Witte Museum (Accession Number 40-83-353), excavated on Leon Creek in 1940, was accompanied by 32 rectangular mussel shell beads which are 
roughly similar to those found in the ditch fill (Fig. 24, i). Word has also come to the author of a site near Losoya on the Medina River where burials have been found accompanied by similar rectangular, two-holed beads (Jake Johnson, personal communication).

Olivella beads identical to the one found are in the George C. Martin coastal collection at the Witte Museum. Similar ones were excavated at Mission San Juan Capistrano (Schuetz 1961: 75). Such beads were probably brought in by coastal tribes, who are known to have been at the missions.

Musse1 shell beads. (Fig. 24, e-h) $13 \mathrm{~mm} \times 7 \mathrm{~mm}$, 2 holes drilled at one side, opposite edge is notched.

Olivella shell bead. (Fig. 24, c) Perforated at one end, ground flat at the opposite end.

\section{BONE}

Bone was found at a11 levels in all types of deposits at this site. An analysis of the animal bone will be found as Appendix 2 to this report.

Bird bone bead. (Fig. 24, d) $5 \mathrm{~cm}$ long. Similar beads have been found at Mission San Juan Capistrano (Schuetz 1969: 76) and in Witte Museum collections from south Texas prehistoric sites.

\section{CHERT}

Fragments of typical Edwards chert were found in all levels during the excavations. Only two projectile points were recovered. One represents a lanceolate series found at other Spanish missions; the second is of the Perdiz type, a form common in late prehistoric sites in central and southern Texas.

Projectile point (Fig. 24, a), length $27 \mathrm{~mm}$, tan Edwards chert. Lanceolate outline with concave base.

Projectile point (Fig. 24; b), length $23 \mathrm{~mm}$, tan Edwards chert. Perdiz type, 1,000 - 1,500 A.D. or later (Suhm and Jelks 1962: 283; Hester and Hill 1971). 


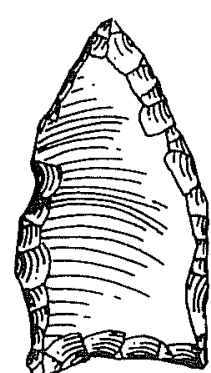

a
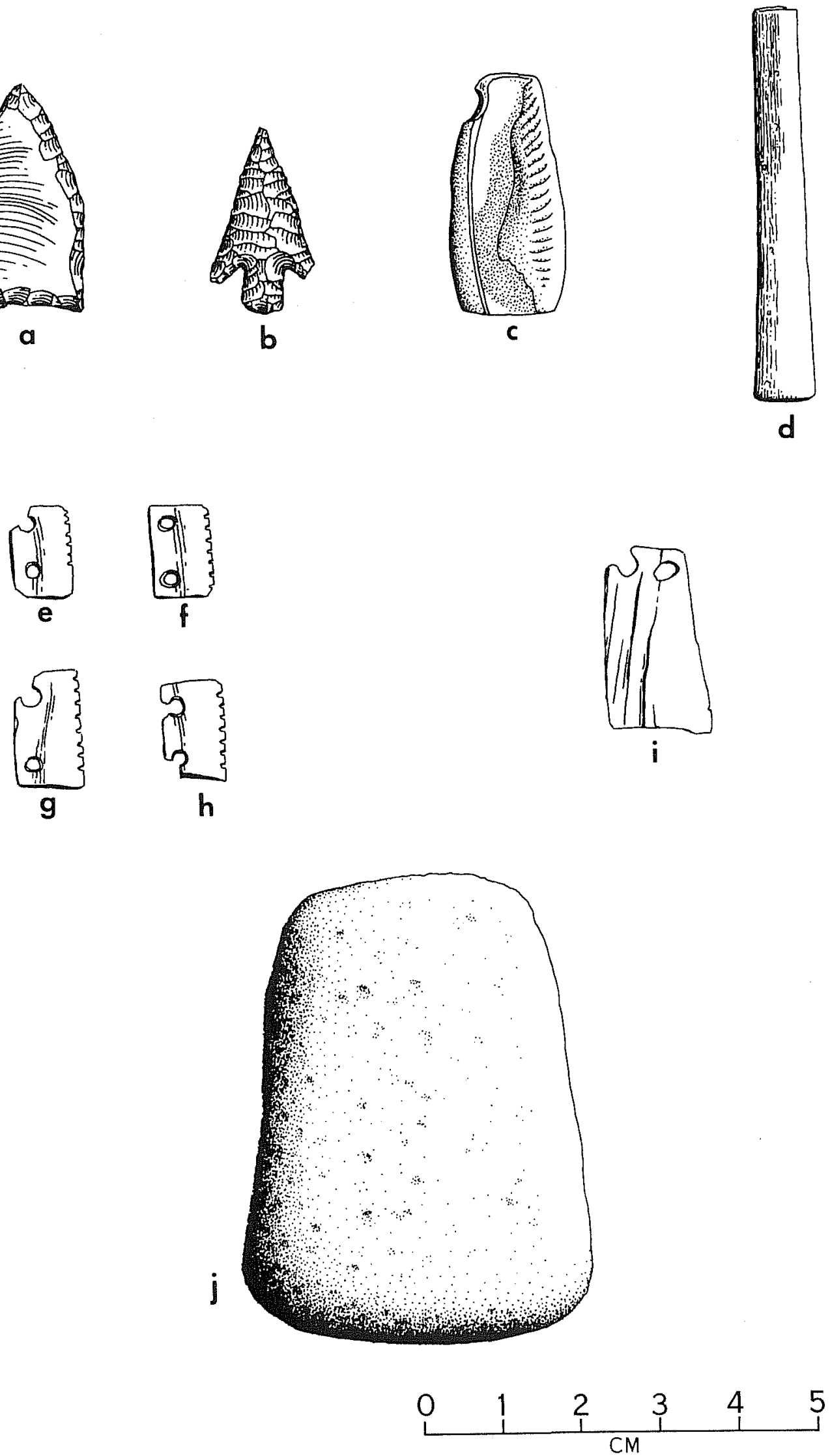

Figure 24. Artifacts from Alamo Plaza. a, projectile point, (tan chert); b, projectile point ( $t a n$ chert); c, Olivella shell bead; d, bird bone bead; $e^{-h}$, mussel shell beads from Alamo ditch; $i$, mussel shell bead from Leon Creek burial site; j, basalt pestle. Drawings by Daniel E. Fox. 
Gun flint. (Fig. 26, i) $28 \mathrm{~mm} \times 34 \mathrm{~mm}$, brown Edwards chert, badly battered. Fits description by John Witthoft of Indian-made gun flints (cited in Hamilton 1960: 73). Musket size (Smith 1960: 40; John Clark, personal communication).

Cores, flakes and fragments. 120

\section{STONE}

Slate fragments, possibly from a slate such as

those used by school children in the 19th century.

Pestle. (Fig. 24, j) dark grey, vesicular basalt, $42 \mathrm{~mm}$ square at base, $58 \mathrm{~mm}$ high. Worn on al1 sides and bottom. Similar grinding tools have been found at most other Spanish sites in Texas.

\section{CARBON}

Battery core, $12 \mathrm{~mm}$ diameter.

\section{IRON}

The presence of nails in most levels of the excavation, and the preponderance of them in the later stratum, is not unexpected, based on experience in similar sites. While nails were available during Spanish mission times, they were scarce and used only where absolutely necessary. Poor preservation of the nails made it impossible to examine them closely for manufacturing details, other than to affirm that they were all square in cross section.

It is interesting to note the small number of iron artifacts in the Spanish Colonial ditch fill, which is not uncommon. The artifacts which are identifiable from the grey level fit into a picture of a wagon parking and perhaps a nearby blacksmith shop in connection with 19 th century plaza usage.

Square nails. 

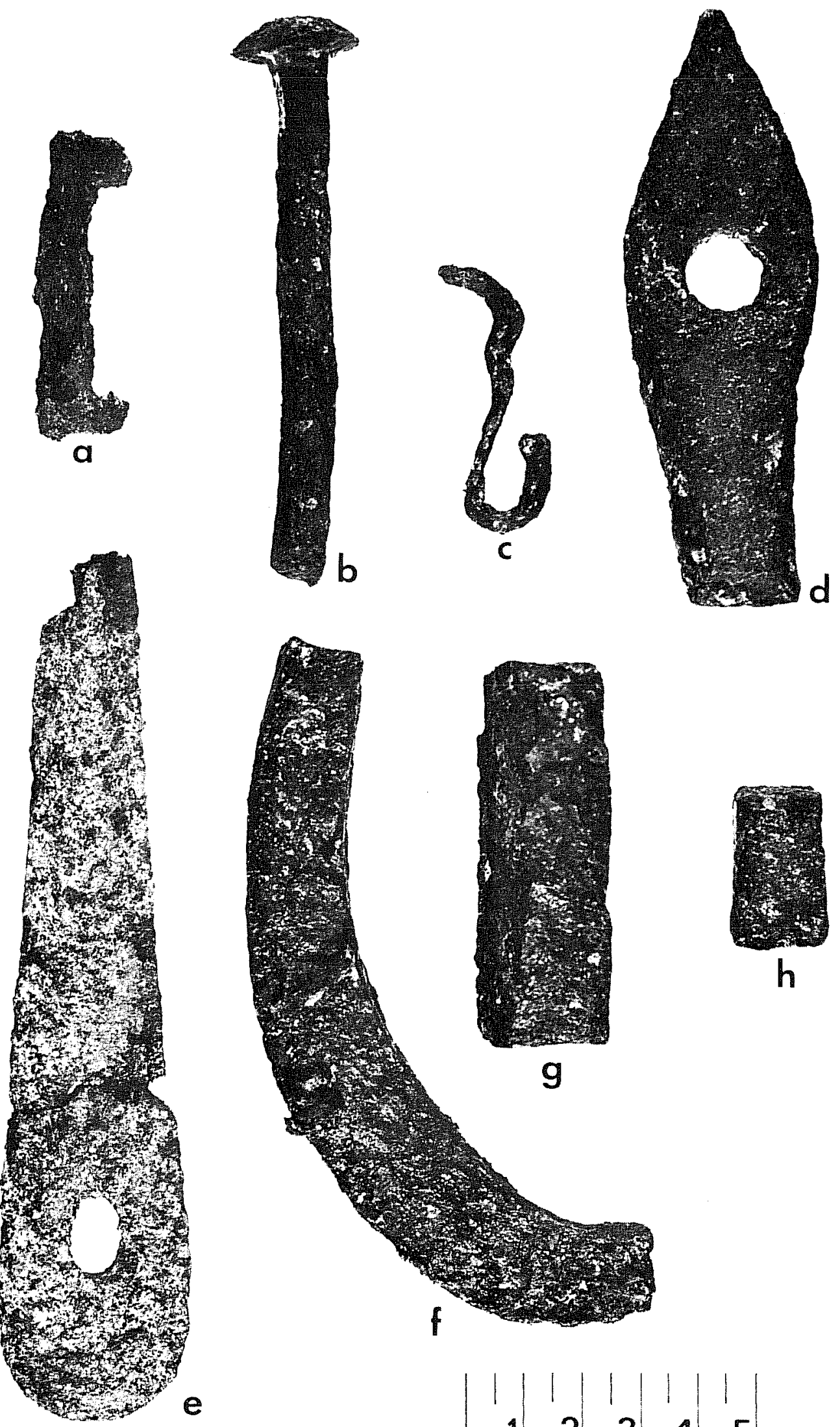

Figure 25. Artifacts from Alamo Plaza. a, iron buckle fragment; b, carriage bolt; $c$, Spanish-type chain Iink; d, wagon hardware fragment; e, iron spoon handle; $f$, horseshoe fragment; $g$, $h$, bar iron fragments. 


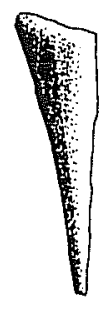

a

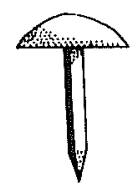

b

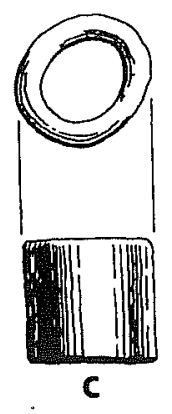

C

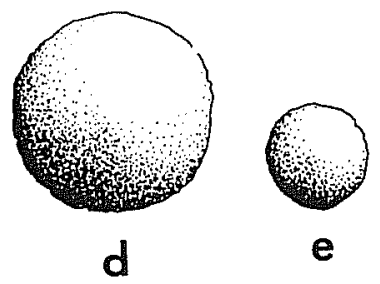

$\frac{\text { 酯 }}{\mathrm{f}}$
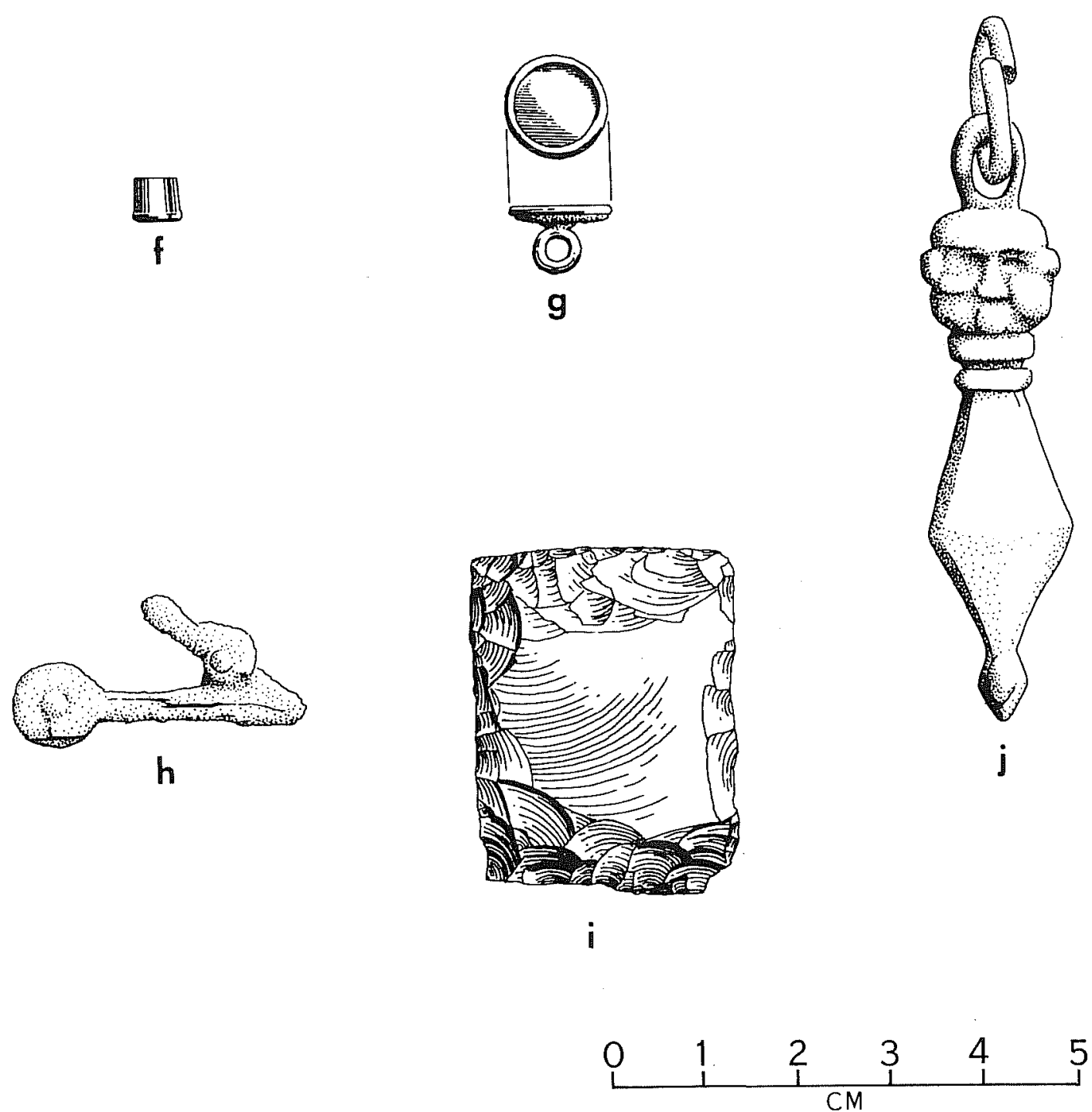

Figure 26. Artifacts from Alamo Plaza. a, pointed fragment of brass or copper; b, copper tack; c, brass ferrule or bead; d, lead musket ball, .68" diameter; e, lead pistol or rifle bal1, . 35" diameter; $f$, percussion cap, brass; g, brass sleeve button; h, sear spring from flintlock; $i$, musket flint (brown chert); $j$, 
Grey

Stratum

Ditch

Wire fragments.

1

Strapping, $3 \mathrm{~mm}$ wide. 1

Strapping, $1.5 \mathrm{~mm}$ wide. 1

Chain link. (Fig. 25, c) S-shaped, Spanish type 1 (DiPeso 1953: 214).

Nut, $2.5 \mathrm{~mm}$ square. 1

Nut, $1.5 \mathrm{~mm}$ square. 1

Carriage bolts. (Fig. 25, b) $9.5 \mathrm{~cm}$ long. 2

Broken pieces of wagon hardware (Fig. 25, d). 3

Horseshoe fragment (Fig. 25, f). 1

Fragments of bar iron. (Fig. 25, g, h) blacksmith 2

or farrier's scrap.

Buckle fragment. (Fig. 25, a) personal apparel. 1

Spoon handle (Fig. 25, e). 1

Sear spring from flintlock (Fig. 26, h)

(Hamilton 1960: 13).

\section{BRASS/COPPER AND OTHER METALS}

As is clearly indicated here, the incidence of metals other than iron is generally much higher in Spanish sites, to the point where finding a fragment of copper is often one of the first signs that one is a mission or presidio site.

Coin (Fig. 19, m) U.S., nickel five cent piece, shield type, 1867-1883, date illegible (Yeoman 1967: 92).

Eraser sleeve from end of pencil. 1

Harmonica reed. 1

Brass drawer or cupboard door pull, (Fig. 26, j) 1 1800-1830 (Noë1 Hume 1970: 230).

Unidentified fragments of copper. 
Grey

Stratum

Ditch

Copper tack. (Fig. 26, b) $13 \mathrm{~mm}$ long, 18th -

19 th century.

Brass/copper pointed fragment (Fig. 26, a),

handmade.

Brass ferrule or bead (Fig. 26, c).

Sleeve button. (Fig. 26, g) brass, $11 \mathrm{~mm}$ diameter.

1837 - 1865 in Florida (South 1964: 122, type 25),

traces of cotton thread remain on eye.

Percussion cap. (Fig. 26, f) $44 \mathrm{~mm}$ diameter, $4.5 \mathrm{~mm}$

long, pistol, $1840^{\prime} \mathrm{s}$ to $1870^{\prime} \mathrm{s}$ (John Clark, personal

communication).

Lead balls. (Fig. 26, d) originally .65" - .69"

diameter, 70 cal. musket (Caldwe11 1964: 199;

John Clark, personal communication).

Lead balls. (Fig. 26, e) originally .35" diameter,

36 cal., pistol (John Clark, personal communication)

or Kentucky rifle (Sam Nesmith, personal communication).

Roll of thin lead fragments.

\section{BUILDING MATERIALS}

Ceramic tile, deep red, dense body.

Ceramic tile, cream, coarse paste.

Ceramic tile, pink, coarse paste.

Brick, cream, $5.2 \mathrm{~cm}$ thick, not machine-made,

19 th century.

Brick or tile, orange-pink, average $3.2 \mathrm{~cm}$

thick, handmade. Similar to Greer's Type I

(1967: 93), common on Spanish sites, 18th to

early 19 th century.

Cut limestone, one smooth face, possibly fragment of a threshold or paving stone.

Plaster or mortar, white, high percentage 
TABLE I

PROVENIENCE OF ARTIFACTS IN DITCH

ZONE I ZONE II ZONE III ZONE IV ZONE V ZONE VI TOTAL

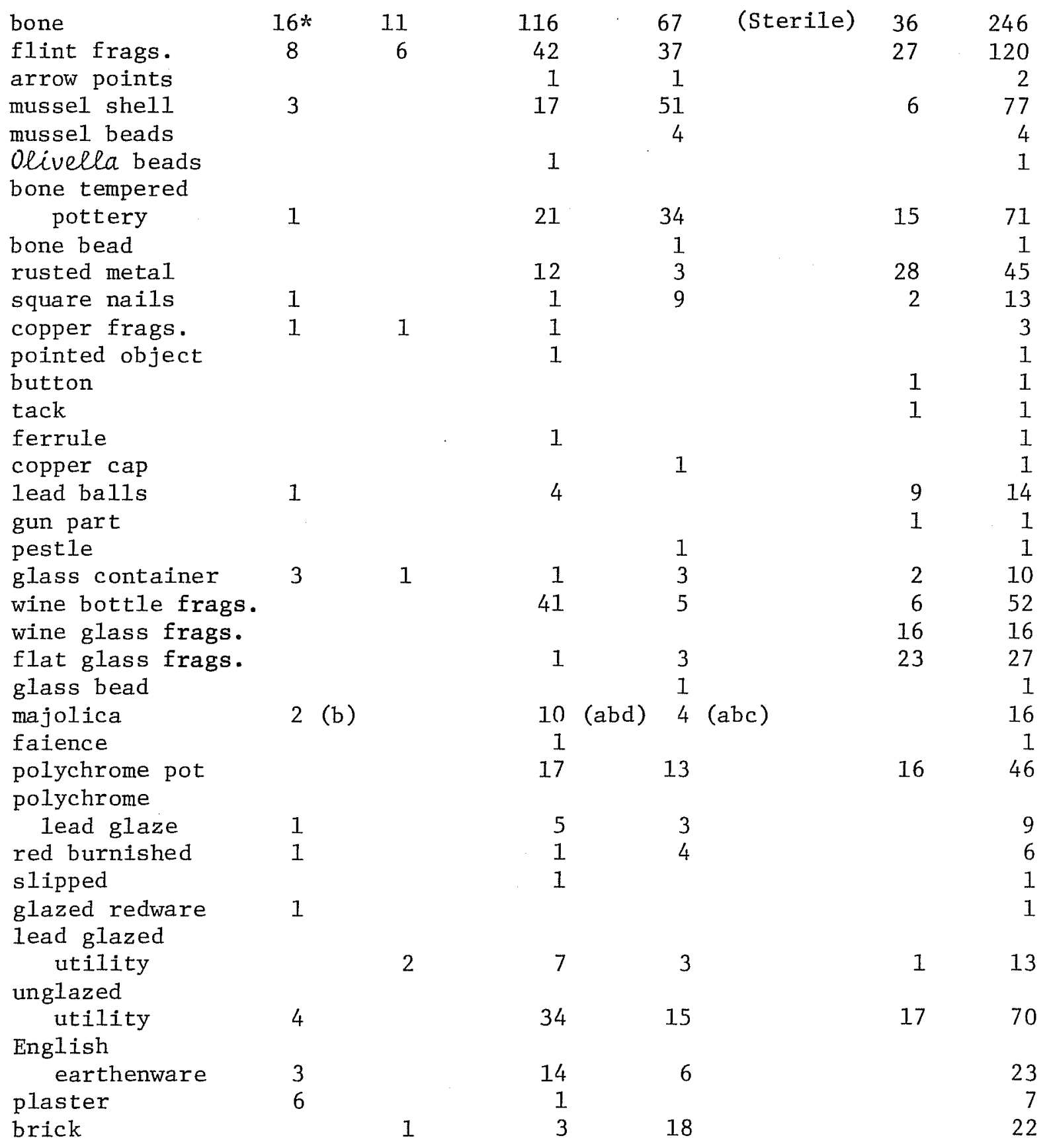

a. Puebla Blue on White, $1700-1850$

b. San Augustine Blue on White, $1700-1750$

c. Aranama Blue on White, $1750-1850$

d. Huejotzingo Blue on White, $1700-1900$

* bone quantities are in ounces 


\section{SUMMARY AND CONCLUSIONS}

In 1975, the Center for Archaeological Research at The University of Texas at San Antonio carried out an archaeological and historical study at Alamo Plaza. Excavations revealed that earlier modifications of the plaza had greatly disturbed the subsurface deposits. However, through the use of careful excavating and recording techniques, several in situ archaeological manifestations were discovered. Although practically all of the south wall of the original Alamo compound had been destroyed, the archaeologists were able to locate footings and other apparent remnants of the structure. The historical review presented earlier in this monograph indicates the nature and extent of the many alterations Alamo Plaza has undergone. Even with such extensive changes, the buried deposit did yield what we believe to be significant information on the Alamo complex.

The following is a tentative chronology of the south wall and its surrounding area, reconstructed from historical and archaeological evidence.

From 1724 when the mission was moved to this location (Ramsde11 1959: 16-17) to sometime soon after 1756, when Fr. Ortiz did not describe a walled enclosure in his report (Ortiz 1756), the area was probably not in use since it was to the south and somewhat removed from the convento. However, the road from the town to the mission probably crossed this spot.

Fr. Dolores' report of 1762 suggests that, in the meantime, a wall which had a gate with a tower had been built around the plaza. Such gates, or sally ports, were a common feature of fortifications in the 18th century, and were sometimes referred to as towers (Manucy 1962: 70). At this time the area outside of the wall, particularly around the gate, would have become a trash dumping area for the mission. This is confirmed by evidence recovered in the excavations. This situation continued until secularization in 1793, when an inventory of the mission described the walls as 3 varas high and $3 / 4$ vara thick, made of stone, adobe and mud, and the gate as measuring 5 varas in width and 4 varas in height (Zacatecas Archives 1793).

The barracks building and jail (carcel) on either side of the gate were probably built by the troops of the Flying Company of San Carlos de Parras del Alamo in 1803 (Smith 1966: 8), since no mention is made of such structures in any of the $18 \mathrm{th}$ century inventories. A similar fortified gate with tower and prison built by the British at Fort Frederica, Florida, in the mid-18th century (Manucy 1962) suggests what this structure may have looked like (Fig. 27).

According to Nixon's (1936: 27) description, materials were ordered for construction of 834 varas of concrete battlement in 1809 . 
Figure 27. Conjectural Reconstruction of South wall. This conjectural reconstruction of the gate, prison, and barracks structure on the south wall is based on information and sketches of a similar building excavated at Fort Frederica in Florida, as well as other 18th century fortifications. 

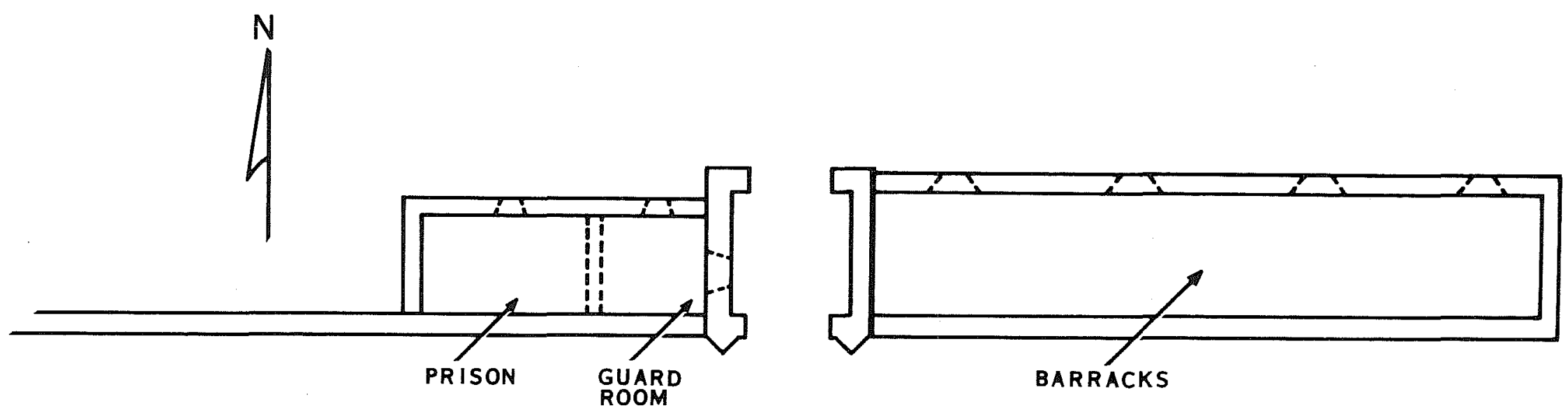

PLAN

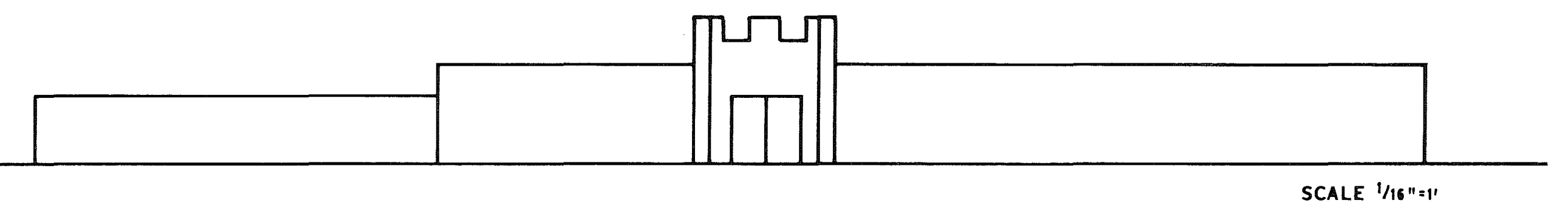

ELEVATION

CONJECTURAL RECONSTRUCTION OF SOUTH WALL 
Unfortunately there was nothing said about where these battlements were to be located, or even whether this was for rebuilding old walls or constructing new ones. Bass believes that the south wall was built at this time on the footings located by the above-described excavations, having previously stood farther north as an extension of the south wall of the convento, as drawn by Menchaca in 1764 (Fig. 3). Fox feels that the archaeological evidence for the colonial midden directly south of the wall, plus the general inaccuracy of the plans of the other missions on Menchaca's map, reinforce her opinion that the wall was built on the present footings sometime in the mid-18th century.

The next alterations made around the south wall were the fortification ditch and breastwork outside the gate, probably built by General Cos when he was fortifying the Alamo in late october of 1835. Sources differ about which fortifications were built by Cos and which by Travis and his men the following Spring, but all agree that they existed by the time of the battle in 1836. This tends to be confirmed by the number of musket balls found in the bottom of the ditch, probably remains of the Mexican assault on the walls.

In May, 1836, General Andrade passed through San Antonio on his way back to Mexico after the Battle of San Jacinto. His orders were to dismantle the fort. According to an eyewitness, "all the single walls were levelled, the fosse (ditch) filled up, and the pickets torn up and burnt" (Huson 1910: 44-45). This action may have included both the picket barricade between the church and the south wall and the fortifications around the gate.

A plan of the entire mission compound drawn by Lt. Edward Everett in 1846 (Hughes 1846) shows the jail, gate and barracks still standing and apparently roofed (Fig. 4). However, the following excerpts from an eyewitness account of the buildings in 1845 give an interesting picture of their construction and their general condition at that time. "Mr. Gentilz (in his painting of the 1836 battle) makes the old rubblestone building flanking the church on the south side of the mission to appear as a cut stone edifice... cacti plants decorated the tumble-down roof of the old building ..." (Everett 1975: 18). Rubble masonry, as the term was used in the late 19th century, was formed of "irregularly shaped stones as they come from the quarry, without other preparation than the removal of acute angles and excessive projections" (I.C.S. 1906: 10).

In 1848 the U.S. Army moved into the Alamo complex and during the next few years cleared the rubble, levelled the area and made major repairs to the structures, replacing the original flat, earthen roofs with pitched shingled ones. At this time the walls of the "low stone barrack" against the south wall were apparently still standing (Brown 1892: 572). Corner (1890: 11) reports, "The carcel was also roofed 
and cleared, and a serviceable granary was made of it and used as such by the Quartermasters for many years. It was demolished soon after the war, the wind beginning this work of destruction in 1866 . This old prison building used to stand east and west across the north end of the garden of the Alamo Plaza..." (see also Barnes 1910: 48).

Apparently, in 1871, a thorough job of plaza-clearing removed the walls of the building, then referred to as "the old galera" (an Americanism for shed), which by this time was a ruin. They scraped the plaza level, redistributing the artifact-laden earthen floors and plaza surface in an attempt to create better drainage and a neater appearance for the plaza (San Antonio Daily Express 1871). This operation removed or scrambled most of the archaeological evidence of earlier periods of occupation, although numerous artifacts in the grey stratum beneath the park fill can be linked to these times.

In 1889 when mesquite block paving was laid in the plaza, the wall footings were again uncovered (Corner 1890: 11), probab1y damaging them still further, and top soil was brought in and spread over the area to create a park which, with minor changes, has continued to the present day.

With the knowledge that some archaeological remains of significance lie buried in Alamo Plaza, we have reviewed the architect's plans for the renovation of the plaza to be carried out in 1976. The review of the plans, and our lengthy conversations with the project and landscape architects, lead us to believe that no damaging subsurface disturbance will result from the renovation. Most of the planned modifications consist of replacing the existing asphalt pavement with stone paving blocks, the planting of trees and grass, replacement of the present bandstand, installation of brick planters, and so forth. None of these activities should penetrate to the depth (approximately 1.5 meters) where in situ archaeological remains might be expected to occur. The project architect, Emmit Tuggle, has assured us that an archaeologist will be immediately contacted should cultural materials be encountered during any phase of the renovation. If plans are modified during the course of the project to include any major subsurface construction, such as the digging of pipeline or drainage ditches, archaeologists should be made aware of these, so that the possibility of disturbance to archaeological resources can be evaluated.

For future consideration in the event that further construction of any type is contemplated within the plaza, the authors recommend that particular care should be taken in the following areas:

1. The campo santo or mission cemetery is located directly in front of the church and extends from the facade to at least a line which is the extension of the west wall of the convento (see Figs. 2 and 5). Numerous burials would probably be encountered in this area by any disturbance which goes deeper than one meter below the present surface. 
2. The stockade and fortification ditch which extended from the southwest corner of the church to the southeast corner of the south wall probably is still represented in some fashion underground. (see Fig. 2). Future archaeological excavations might reveal these remains and determine the exact location of this feature.

3. Somewhere near the southeast corner of the convento was a well, possibly dating from mission times, but certainly from the time of the seige in 1836. The contents of this well should be examined for research purposes if it is ever located. Also in this area there may be footings of an earlier south wall (see Fig. 3).

4. Some artists have indicated an extension of the acequia which connected the one to the east of the church with the one to the west of the mission, outside the south wall. Buried remains of this acequia should still be visible if indeed it ever existed.

In conclusion, we wish to emphasize that the Alamo Plaza research of 1975 has suggested the potential for further archaeological investigations in the plaza zone. We believe that any future construction which involves subsurface disturbance should be preceded by archaeological and historical research. 
APPENDIX 1

INVENTORY OF PARK FILL*

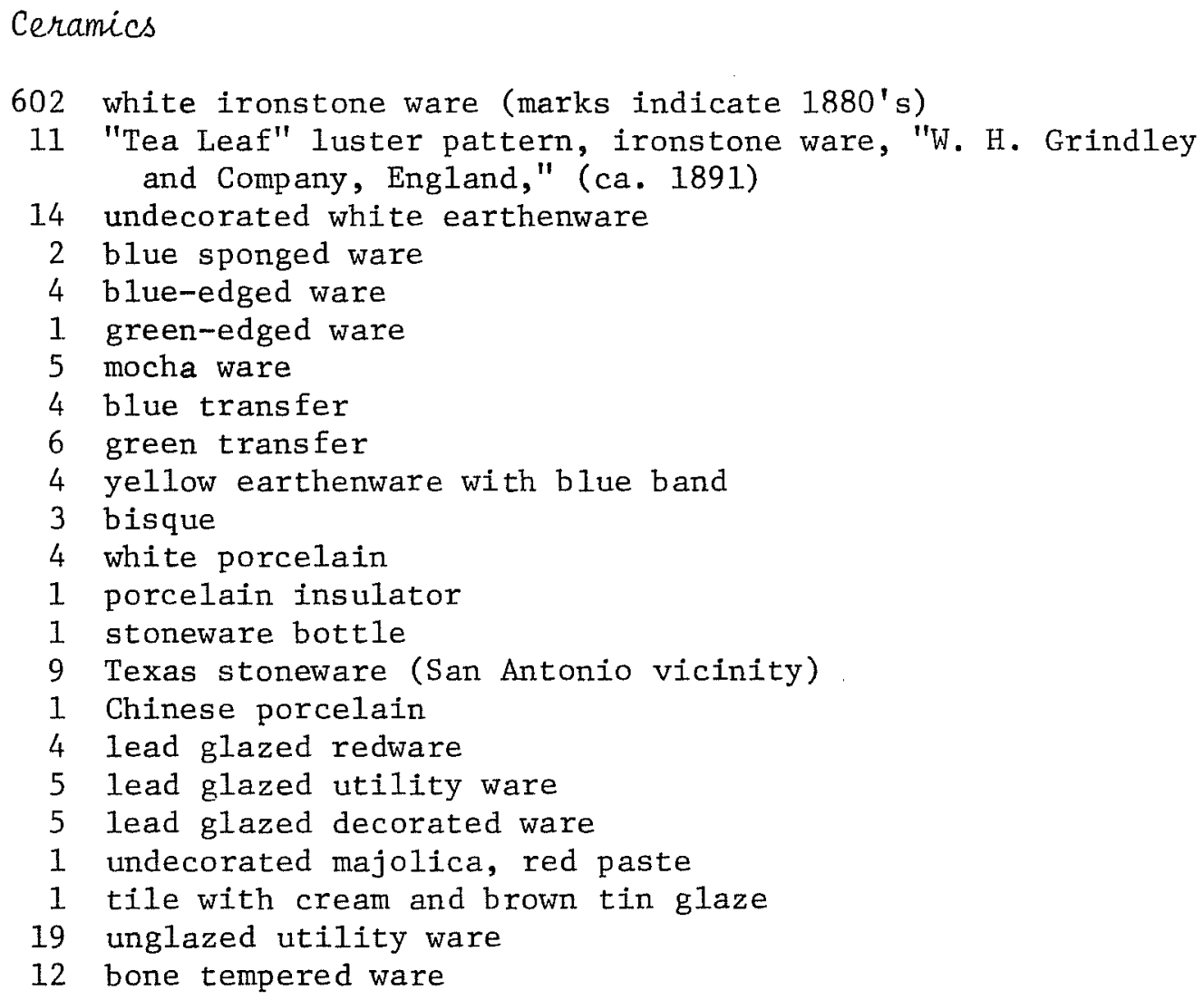

\section{Glass}

34 brown (bottles - late 19th century)

50 green, predominantly dark (bottles - late 19th century)

83 turquoise (containers - 1860 plus)

5 amber

1 blue

41 clear (molded goblets, lamp chimneys)

3 milk glass

\section{Brick and Tile}

3 brick, 2 handmade

5 sewer tile

* A11 numbers indicate fragments unless otherwise noted. 


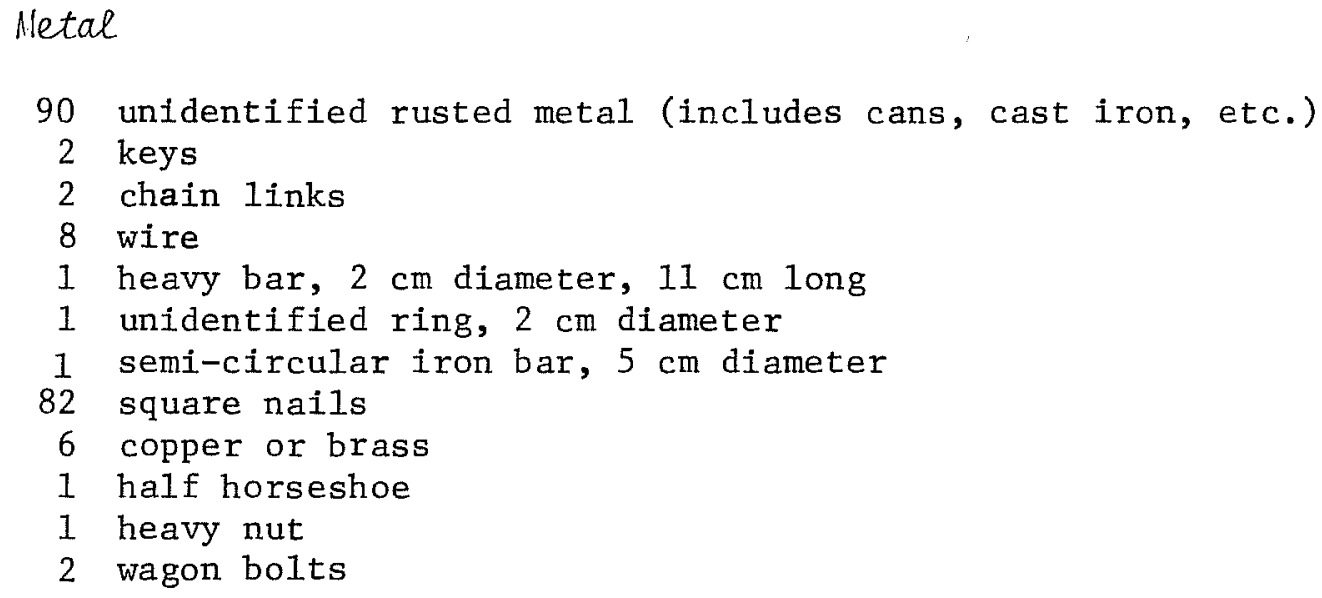

Miscellaneous

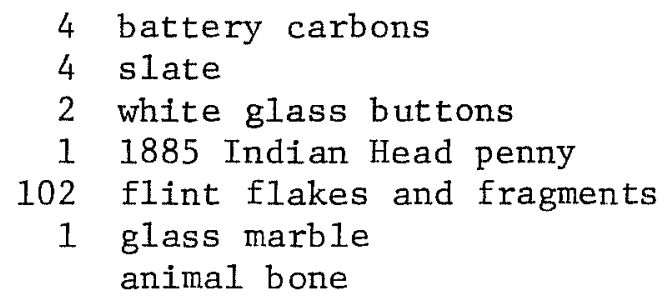


This appendix has been arranged by Anne Fox from an analysis of all animal bone from the excavations. The analysis was done by Billy Davidson of Austin, Texas. Mammals are denoted as either adult or juvenile; weights are indicated as size indicators for reptiles.

Park Fill

422 unidentified fragments, 44 cut by saw, 9 "round steak" bones

Bovid

(cow or bison)

Sus scrofa

(domestic pig)

Capra sp.

(goat)

ovis sp.

(sheep)

Equus sp.

(horse or burro)

Gallus gallus

(chicken)

Sylvilagus sp.

(cottontail)

Pseudemys sp. (slider turtle)

Lepisosteus sp. proximal end humerus

distal end scapula

proximal end radius

proximal end metapodial

2 carpals (probably cow)

astragalus

distal end scapula

tooth fragment

proximal end humerous

proximal end metapodial

proximal end metapodial

phalange

proximal end metapodial

distal end tibia

calcaneus

2 tooth fragments

distal end tibia

carpal

proximal end humerus

pelvis

1 she11 fragment

jaw fragment adult

"

"

"

"1

"

"

$"$

juvenile

adult

juvenile

adult

juvenile adult

II

adult

adult

adult

adult

$51 \mathrm{bs}$.

7 Ibs.

Grey Level

470 unidentified fragments, 8 cut by saw, 1 "round steak" bone 


\begin{tabular}{|c|c|c|}
\hline Bovid & $\begin{array}{l}\text { carpal } \\
\text { distal end tibia } \\
\text { carpal }\end{array}$ & $\underset{" 1 "}{\text { adult }}$ \\
\hline Sus scrofa & $\begin{array}{l}\text { phalange } \\
\text { jaw fragment } \\
\text { proximal end metapodial }\end{array}$ & $\begin{array}{l}\text { juvenile } \\
\text { adult } \\
\text { " }\end{array}$ \\
\hline Capra sp. & $\begin{array}{l}\text { phalange } \\
\text { tooth fragment }\end{array}$ & $\underset{" \text { adult }}{\operatorname{at}}$ \\
\hline Gallus gallus & $\begin{array}{l}\text { tarsometatarsus } \\
\text { coracoid }\end{array}$ & adult \\
\hline $\begin{array}{l}\text { Odocoileus virginianus } \\
\text { (white-tail deer) }\end{array}$ & tibia & old adult \\
\hline $\begin{array}{l}\text { Neotoma cf. micropus } \\
\text { (South Plains Pack Rat }\end{array}$ & jaw & adult \\
\hline $\begin{array}{l}\text { Meleagris gallopavo } \\
\text { (wild turkey) }\end{array}$ & phalange & adult \\
\hline Lepisosteus sp. & jaw fragment & 7 1bs. \\
\hline Pseudemys sp. & 1 shell fragment & 5 lbs. \\
\hline $\begin{array}{l}\text { Rana sp. } \\
\text { (frog) }\end{array}$ & tibia & 2 1bs. \\
\hline
\end{tabular}

Fortification Ditch

Bovid

1 tooth, 4 fragments carpal

5 tooth fragments ( 1 tooth)

3 teeth, 4 fragments

5 carpals

2 hooves

2 phalanges, 1 fragment proximal and distal ends femur carpal

proximal femur fragment

old adult

adult

$" 1$
$" 1$
$" 1$

young adult juvenile

Sus scrofa

tooth

adult

Capra

tooth

tooth

carpa1

phalange

astragalus

carpa1

2 phalanges

very old adult old adult

" "

adult

"

"1 


\begin{tabular}{|c|c|c|}
\hline & $\begin{array}{l}\text { tooth } \\
\text { pelvic fragment } \\
\text { tooth } \\
\text { proximal end metapodial } \\
\text { phalange }\end{array}$ & $\begin{array}{l}\text { adult } \\
\text { juvenile } \\
\text { " } \\
\text { " }\end{array}$ \\
\hline ovis & proximal end metapodial & juvenile \\
\hline Equus sp. & $\begin{array}{l}\text { astragalus fragment } \\
\text { splint bone }\end{array}$ & $\underset{"}{\text { adult }}$ \\
\hline $\begin{array}{l}\text { Canis sp. } \\
\text { (dog or coyote) }\end{array}$ & $\begin{array}{l}\text { tooth } \\
\text { baculum } \\
\text { vertebra }\end{array}$ & $\begin{array}{l}\text { adult } \\
\text { " } \\
\text { young adult }\end{array}$ \\
\hline odicoileus virginianus & $\begin{array}{l}\text { hoof } \\
\text { calcaneus } \\
\text { astragalus } \\
\text { axis } \\
\text { phalange } \\
\text { proximal end ulna } \\
\text { tooth } \\
\text { carpal } \\
\text { distal end radius } \\
2 \text { proximal ends femurs } \\
\text { proximal end tibia } \\
\text { proximal end metapodial }\end{array}$ & $\begin{array}{l}\text { adult } \\
" \\
" \\
" \\
" \\
" \\
" \\
\text { juvenile } \\
" \\
" \\
"\end{array}$ \\
\hline Gallus gallus & $\begin{array}{l}\text { metatarsal } \\
2 \text { vertebrae } \\
\text { wing phalange } \\
2 \text { distal ends tibia } \\
\text { proximal end tibia } \\
\text { distal end ulna } \\
\text { proximal end radius } \\
\text { phalange } \\
2 \text { femurs } \\
\text { pelvic fragment } \\
\text { jaw fragment } \\
2 \text { fibulae } \\
\text { ulna } \\
\text { sacrum }\end{array}$ & $\begin{array}{l}\text { adu1t } \\
\text { " } \\
\text { " } \\
\text { " } \\
\text { " } \\
\text { " } \\
\text { " } \\
\text { " } \\
\text { " } \\
\text { " }\end{array}$ \\
\hline Meleagris gallopavo & $\begin{array}{l}\text { distal end femur } \\
\text { distal end tarsometatarsus }\end{array}$ & $\underset{1 "}{\operatorname{adult}}$ \\
\hline $\begin{array}{l}\text { Chen sp. } \\
\text { (blue or snow goose) }\end{array}$ & distal end of humerus & adult \\
\hline $\begin{array}{l}\text { Zenaldura cf. macroura } \\
\text { (mourning dove) }\end{array}$ & humerus & adult \\
\hline
\end{tabular}


Procyon lator
(raccoon)

Sciurus sp.

(tree squirrel)

Neatoma sp.

Sigmodon hispidus (cotton rat)

Sylvilagus sp.

Lepus californicus

(blacktail jackrabbit)

Pseudemys sp.

Terrapene sp.

(box turtle)

Trionix sp.

(softshe11 turtle)

Kinosternon sp.

(mud turtle)

Ictalurus sp.

(catfish)

Aplodinotus grunniens (drum)

Micropterus sp.

(black bass)

Elaphe sp.

(rat snake)

Crotalus sp.

(rattlesnake) proximal end radius

metatarsal

phalange

vertebra

femur

2 proximal ends femur

proximal end ulna

humerus

maxilla

vertebra

radius

metatarsal

1 shell fragment

2 shell fragments

1 shell fragment

4 shel1 fragments

1 shel1 fragment

4 shell fragments

shell fragment

shell fragment

2 she11 fragments

3 shell fragments

vertebra

skull fragment

9 vertebrae

9 vertebrae

3 vertebrae

5 spinal bulbs

skul1

gill cover

4 vertebrae

skull

2. vertebrae

1 vertebra

1 vertebra

femur $\underset{n}{\operatorname{adu} 1 t}$

"

adult

adult

adult

adult

"

adult

5-7 1bs.

5 1bs.

6 1bs.

3 1bs.

4 1bs.

4 lbs.

5 1bs.

6 lbs.

$6 \mathrm{oz}$.

$1 \mathrm{lb}$.

$1 \frac{1}{2}$ Ibs.

3 lbs.

3 1bs.

3 1bs.

2 1bs.

2 lbs.

4 1bs.

4 1bs.

4 1bs.

2 lbs.

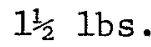

2 lbs.

3 1bs. 
APPENDIX 3

FAUNAL PROVENIENCE CHART

\begin{tabular}{|c|c|c|c|c|c|c|}
\hline & I & II & $\begin{array}{l}\text { DITCH } \\
\text { III }\end{array}$ & IV & $\mathrm{V}$ & $\begin{array}{l}\text { GREY } \\
\text { STRATUM }\end{array}$ \\
\hline Bovid & $\mathrm{X}$ & $\mathrm{X}$ & $\mathrm{x}$ & $\mathrm{x}$ & $\mathrm{x}$ & $\mathrm{X}$ \\
\hline Sus scrofa & & & & $\mathrm{x}$ & & $\mathrm{X}$ \\
\hline Capra sp. & & & $\mathrm{x}$ & $\mathrm{X}$ & $\mathrm{X}$ & $\mathrm{X}$ \\
\hline ovis sp. & & $\mathrm{X}$ & & & & \\
\hline Equus sp. & & & $\mathrm{X}$ & $\mathrm{x}$ & & \\
\hline Canis sp. & & & $\mathrm{x}$ & $\mathrm{X}$ & & \\
\hline odocoileus virginianus & $x$ & $\mathrm{x}$ & $\mathrm{X}$ & $\mathrm{X}$ & $\mathrm{x}$ & $\mathrm{x}$ \\
\hline Gallus gallus & & $\mathrm{X}$ & $\mathrm{x}$ & $\mathrm{X}$ & $\mathrm{X}$ & $\mathrm{X}$ \\
\hline Meleagris gallopavo & $x$ & & $\mathrm{X}$ & & & $\mathrm{X}$ \\
\hline Chen sp. & & & $\mathrm{x}$ & & & \\
\hline $\begin{array}{c}\text { Zenaldura } c b . \\
\text { macroura }\end{array}$ & & & $\mathrm{X}$ & & & \\
\hline Procyon lotor & $\mathrm{x}$ & & $\mathrm{X}$ & & $\mathrm{X}$ & \\
\hline Sciurus sp. & & & $\mathrm{X}$ & & & \\
\hline Neotoma sp. & & & $\mathrm{X}$ & $\mathrm{X}$ & & \\
\hline Sigmodon hispidus & & & & $\mathrm{X}$ & & \\
\hline Sylvilagus & $\mathrm{x}$ & & & $\mathrm{X}$ & & \\
\hline Lepus californicus & & & $\mathrm{X}$ & $\mathrm{X}$ & & \\
\hline Pseudemys sp. & & $\mathrm{X}$ & $\mathrm{X}$ & & & \\
\hline Terrapene sp. & & $\mathrm{X}$ & $\mathrm{X}$ & $\mathrm{X}$ & $\mathrm{X}$ & \\
\hline Trionix sp. & $\mathrm{X}$ & $\mathrm{x}$ & $\mathrm{x}$ & $\mathrm{X}$ & $\mathrm{x}$ & \\
\hline Kinosteruon sp. & $\mathrm{X}$ & & $\mathrm{x}$ & $X$ & & \\
\hline unidentified turtle & & $\mathrm{X}$ & & & & \\
\hline
\end{tabular}




$\begin{array}{llclll}\text { I } & \text { DITCH } & & & \text { GREY } \\ & \text { III } & \text { IV } & V & \text { STRATUM }\end{array}$

Lepisosteus sp.

Ictalurus sp.

Alpodinotus grunniens

Micropterus sp.

unidentified fish

Elaphe sp.

Crotalus sp.

Rana sp.

unidentified

(No. of fragments)
III

$\mathrm{X}$

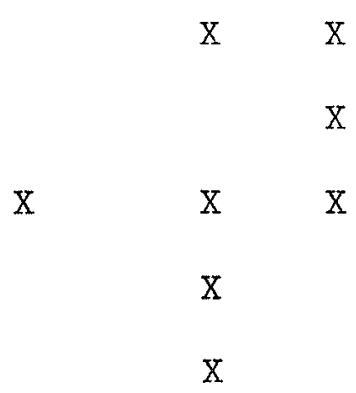

$\mathrm{X}$

258

139

2,265

$1,604 \quad 641$

$\mathrm{X}$

470 


\section{BIBLIOGRAPHY}

Adams, R. E. W. and Thomas R. Hester

1973 Letter to Dr. Fred Wendorf, Chairman, Texas Antiquities Committee, concerning completion of excavations at Mission San Antonio de Valero, November 26.

Arneson, Edwin P.

1921 Early Irrigation in Texas. Southwestern Historical quarterly, Vo1. 25: 121-130.

Babbitt, E. B.

1849 Letter to Major General T. S. Jessup, Quartermaster General, Washington, D.C., August 18, 1849. On file, Office of the Quartermaster General, San Antonio, National Archives, Washington.

Bailey, Thomas A.

1955 A Diplomatic History of the American People. Appleton-Century-Crofts Inc., New York.

Bannon, John Francis (Editor)

1964 Bolton and the Spanish Borderlands. University of Oklahoma Press, Norman.

Barker, Eugene C. (Editor)

1929 Texas History. Southwest Press, Dallas.

Barnes, Charles Merritt

1910 Combats and Conquests of Immortal Heroes. San Antonio. Barnes, Mark R.

1974 Letter to Anne Fox concerning identification and dating of lead glazed wares from Tucson Urban Renewal excavations.

Barnes, Mark R. and Ronald V. May

1972 Mexican Majolica in Northern New Spain. Pacific Coast Archaeological Society Occasional Paper, No. 2.

Benedict, J.W.

1929 Diary of a Campaign Against the Comanches. Southwestern Historical Quarterly, Vo1. 32: 300-310. 
Bolton, Herbert E.

1907 Spanish Mission Records at San Antonio. Southwestern Historical Quarterly, Vo1. 10: 297-307.

1915 Texas in the Middle of the Eighteenth Century. University of California Press, Berkeley.

Brown, John Henry

1892 History of Texas 1685-1892. Vol. I., St. Louis.

Burke, James Wakefield

1971 Missions of Oed Texas. A. S. Barnes and Company., New York.

Caldwel1, Warren W.

1960 Preliminary Notes on Fragments of Firearms and Related Objects from Fort Atkinson, 1820-1827, Indian Trade Guns (compiled and arranged by T. M. Hamilton). The Missouri Archaeologist, Vo1. 22: 192-200.

Castañeda, Carlos E.

1928 The Mexican Side of the Texas Revolution. Dallas.

1936 Our Catholic Heritage in Texas. Von Boeckman-Jones Company, Austin.

The Mission Era, The Finding of Texas 1519-1693. Vol. I.

The Mission Era, The Uinning of Texas 1693-1731. Vol. II.

1938 The Mission Era, The Missions at Work 1731-1761. Vol. III.

1939 The Mission Era, The Passing of the Missions 17621782. Vo1. IV.

1942 The Mission Era, The End of the Spanish Regime 1780-1810. Vol. V.

1950 Transition Periad, The Fight for Freedom. Vo1. VI.

Cervantes, Gonzalo Lopez

1974 Porcelana Europea en México. Boletin, Instituto Nacional de Antropologia e Historia 9, Epoca II, $49-52$. 
Chabot, Fredrick C.

1930 Indians and Missions. San Antonio.

1931 Alamo Altar of Texas Liberty. San Antonio.

1931 San Antonio and its Beginnings 1691-1731. Nay1or Printing Company, San Antonio.

1941 The Alamo, Mission Fortress and Shrine. San Antonio.

1941 Texas in 1811, The Casas and Sambrano Revolution. Yanaguana Society, San Antonio.

Conner, John E.

1945 The Centennial Record of the San Antonio Army Service Forces Depot. U.S. Army, San Antonio.

Corner, William

1890 San Antonio de Bexar. Brainbridge and Corner, San Antonio.

DiPeso, Charles C.

1953 The Sobaipuri Indians of the Upper San Pedro River Valley, Southeastern Arizona. The Amerind Foundation Publications 6. Dragoon, Arizona.

Dolores, Fray Mariano Francisco de los

1762 Documentos Para la Historia Eclesiástica y Civil de la Provincia de Texas o Nuevo Philipinas, 17201779. Colección Chimalistac de Libros y Documentos Acerca de 1a Nueva España 12, Ediciones José Porrúa Turanzas, Madrid, 1964.

Emslie, George C.

1960 Information supplied upon request to Cecil A. Calhoun, September 8, 1960.

Everett, Donald E.

1975 San Antonio, The Flavor of its Past, 1845-1898. Trinity University Press. San Antonio.

Fox, Anne Adams

1974 Lead Glazed Wares. In: Mission Rosario Archeological Investigations 1973. Texas Parks and Wildlife Department, Parks Division, Historic Sites and Restoration Branch, Archeological Report, No. 14, Part 1: 55-60. 
Freeman, Martha

1972 A History and Chronology of Public Markets in San Antonio. Alamo Library, San Antonio.

Freeman, W. G., Lt. Col.

1853 Report of Inspection of Quartermaster Depot at the Alamo. Office of the Quartermaster General,San Antonio, National Archives, File Box No. 1 .

Garrett, Julia Kathryn

1939 Green Flag Over Texas. Cordova Press Inc., New York.

Garza, Leonard (Editor)

1913 (Judge J. M.) Rodriguez Memoirs of Early Texas. San Antonio.

Gentilz, Theodore

n.d. Scale drawing of the Alamo chapel and south wall areas, done in preparation for a painting of the 1836 battle. Daughters of the Republic of Texas Library.

Gerald, Rex E.

1968 Spanish Presidios of the Late Eighteenth Century in Northern New Spain. Museum of New Mexico Research Records, No. 7.

Gibson, Charles

1966 Spain in America. Harper and Row, N.Y.

Gilmore, Kathleen

1967 A Documentary and Archeological Investigation of Presidio San Luis de las Amarillas and Mission Santa Cruz de San Saba, Menard County, Texas. A Preliminary Report. State Building Commission Archeological Program, Report No. 9.

1969 The San Xavier Missions, A Study in Historical Site Identification. State Building Commission Archeological Program, Report No. 16.

1974 Mission Rosario, Archeological Investigations 1973. Texas Parks and Wildlije Department, Parks Division, Historic Sites and Restoration Branch, Archeological Report, No. 14, Part 1. 
Goggin, John M.

1968 Spanish Majolica in the New World. Yale

University Publications in Anthropology, 72.

Greaser, Arlene and Paul H. Greaser

1964 Homespun Ceramics, A Study of Spatterware. A. B. E. Printing Company, Allentown, $\mathrm{Pa}$.

Greer, John W.

1967 A Description of the Stratigraphy, Features and Artifacts from an Archeological Excavation at the Alamo. State Building Commission Archeological Program, Report No. 3.

Habig, Marion A.

1968 The Alamo Chain of Missions. Franciscan Herald Press, Chicago.

Hamilton, T. M.

1960 Additional Comments on Gunflints, Indian Trade Guns (compiled and arranged by T. M. Hamilton). The Missouri Archaeologist, Vol. 22: 73-79.

1960 The Determination and Origin of Archaeological Gun Parts, Indian Trade Guns (compiled and arranged by $T$. M. Hamilton). The Missouri Archaeologist, Vo1. 22: 5-15.

Harris, R. King and Inus Marie Harris

1967 Trade Beads, Projectile Points, and Knives. A Pilot Study of Wichita Indian Archaeology and Ethnohistory (Assembled by Robert E. Be11, Edward B. Jelks, W. W. Newcomb), National Science Foundation Report: 129-162.

Hatch, Joseph Addison

1910 Affidavit. Alamo Library, San Antonio

Hatcher, Mattie Austin

1927 The Opening of Texas to Foreign Settlement 1801-1821. University of Texas Press, Austin. 
Hester, T. R.

1968 Notes on Pottery-Bearing Sites in Southern Texas. Bull-Roarer, Vo1. 3, No. 2: 9-11. The University of Texas Anthropological Society.

Hester, T. R., and T. C. Hill, Jr.

1971 An Initial Study of a Prehistoric Ceramic Tradition in Southern Texas. Plains Anthropologist, Vo1. 16, No. 53: 195-203.

Holton, W. Eugene and Ruth L. Butler (editor)

1956 William Bollaert's Texas. University of Oklahoma Press, Norman.

Horgan, Paul

1954 Great River, The Rio Grande in North American History. 2 Volumes. Rinehart and Company, Inc., New York.

Hughes, Captain George W.

1846 Memoir Descriptive of the March of a Division of the United States Army Under the Command of Brigadier General John E. Wool from San Antonio de Bexar to Saltillo in Mexico. Senate Documents of the first session of the 31st U.S. Congress, Vo1. 10, Document 32 .

Humboldt, Alejandro de

1941 Ensayo Político Sobre el Reino de la Nueva España (edited and annotated by Vito Alessio Robles)

Vol. 4, Editorial Pedra Robredo, Mexico.

Hunter, John W. and Carlos Beltram

1940 Some Early Tragedies of San Antonio: The Autobiography of Carlos Beltram. Frontier Times, December: 115-140.

Huson, Hobart (editor)

1949 Dr. J. H. Barnard Journal. Goliad Bicentennial Edition.

Hussey, Roland Dennis

1963 Colonial Economic Life, in Colonial Hispanic America (edited by Curtis Wilgus). Russell and Russell, N.Y. 
I.C.S. Reference Library

1906 Stone and Brick Masonry. Internationa1 Textbook Company, London.

James, Vinton Lee

1938 Frontier and Pioneer Recollections of Early Days in San Antonio and West Texas. San Antonio.

Jenkins, John H.

1973 Papers of the Texas Revolution. 10 Volumes. Presidial Press, Austin.

Leutenegger, Fr. Benedict

1973 The Zacatecan Missionaries in Texas 1716-1834. Texas Historical Survey Committee, office of the State Archeologist, Report No. 23.

Lister, Florence C. and Robert H. Lister

1975 Non-Indian Ceramics from the Mexico City Subway El Palacio, Vol. 81, No. 2: 25-48.

Manucy, Albert C.

1962 The Fort at Frederica. Notes in Anthropology, vol. 5, Florida State University.

McClintock, William A.

1930 Journal of a Trip Through Texas and Northern Mexico in 1846-1847. Southwestern Historical Quarterly, Vo1. 34: 141-157; 231-250.

McClinton, Katherine Morrison

1951 Antique Collecting for Everyone. Bonanza Books, New York.

Moore, Francis, Jr.

1840 Map and Description of Texas. Tanner and Disturnel1, New York.

Morrison-Fourmy (Editors)

1888 Morrison and Fourmy's General Directory of the City of San Antonio 1889-1890. Galveston. 
Mounger, Maria Allen

1959 Mission Espíritu Santo of Coastal Texas: An Example of Historic Site Archeology. M.A. Thesis, The University of Texas, Austin.

Newcomb, Pearson

1926 The Alamo City. Standard Printing Company Press, San Antonio.

Newcomb, W. W., Jr.

1961 The Indians of Texas. University of Texas Press, Austin.

Newman, T. Ste11

1970 A Dating Key for Post-Eighteenth Century Bottles. Historical Archaeology, Vo1. 4: 70-75.

Nixon, Pat Ireland

1936 A Century of Medicine in San Antonio. San Antonio.

Noë1 Hume, Ivor

1970 A Guide to Artifacts of Colonial America. Knopf, New York.

1975 Letter to Anne Fox concerning dating of early 19th century wine glasses, August 8 .

Odin, John Mary

1840- Journal 1840-1852. Texas Materials in the Calendared

1852 Papers. Microfilm Roll \# 1, 1831-1862: Notre Dame Archives, Notre Dame University.

01msted, Fredrick

1857 A Journey Through Texas or a Saddle Trip on the Southwestern Frontier. New York.

Ortiz, Fray Francisco Xavier

1955 Razon de la Visita a las Misiones de la Provincia de Texas - 1756. (edited by Vargas Rea). Del Fondo Franciscano-Archivo de Museo-Paleografiado por e1 Sr. Raymundo Luna Olmedo.

Pioneer Flour Mills

1951 100th Anniversary Pioneer Flour Mills San Antonio Texas, 1851-1951. Naylor Company, San Antonio. 
Ramsde11, Charles

1959 San Antonio, A Historical and Pictorial Guide. The University of Texas Press, Austin.

Reynolds, J. J., Bvt. Major General

1968 Description Book of Districts of Texas. U.S. Army, San Antonio, Texas.

Roberson, Wayne R.

1974 The Carrington-Covert House, Archeological Investigation of a 19th Century Residence in Austin, Texas. Texas Historical Commission, Office of the State Archeologist Report No. 25.

Santos, Richard G.

1968 Santa Anna's Campaign Against Texas, 1835-1836. Texian Press, Waco, Texas.

Schuetz, Mardith K.

1966 Historic Background of the Mission San Antonio de Valero. State Building Commission Archeological Program, Report No. 1.

1968 Historical Documentation and Description of the Structures. The History and Archaeology of Mission San Juan Capistrano, San Antonio, Texas I, State Building Commission Archeological Program, Report No. 10.

1969 Description of the Artifacts and Ethno-History of the Coahuiltecan Indians. The History and Archaeology of Mission San Juan Capistrano, San Antonio, Texas II, State Building Commission Archeological Program, Report No. 11 .

1970 Excavation of a Section of the Acequia Madre in Bexar County, Texas, and Archaeological Investigations at Mission San José in Apri1, 1968. Texas Historical Survey Committee, Archeological Report, No. 19, Aus tin.

1973 Archeological Investigations at Mission San Antonio de Valero, the Second Patio. Unpublished manuscript, office of State Archeologist.

Smith, Carlyle S.

1960. Two 18th Century Reports on the Manufacture of Gunflints in France, Indian Trade Guns (compiled and edited by T. M. Hamilton). The Missouri Archaeologist, Vo1. 22: 40-69. 
Smith, Cornelius C., Jr.

1967 William Sanders Oury, History Maker of the Southwest. University of Arizona Press, Tucson.

Smith, Horace R.

1966 History of Alamo Plaza from its Beginning to the Present. M.A. Thesis, Trinity University, San Antonio.

Sorrow, William M.

1972 Archeological Salvage Excavations at the Alamo (Mission San Antonio de Valero) 1970. Texas Archeological Salvage Project, Research Report, No. 4.

South, Stanley

1964 Analysis of the Buttons from Brunswick Town and Fort Fisher. Florida Anthropologist, Vo1. 17, No. 2. 113-133.

1972 Evolution and Horizon as Revealed in Ceramic Analysis in Historic Archaeology. The Conference on Historic Site Archaeology Papers 1971, Vol. 6, Part 1, University of South Carolina.

Stiff, Edward

1840 The Texan Emigrant. George Condin, Cincinnati.

Story, Anna B.

1938 The Alamo from its founding to 1937. M.A. Thesis, The University of Texas, Austin.

Suhm, Dee Ann and Edward B. Jelks

1962 Handbook of Texas Archaeology: Type Descriptions. Texas Archeological Society Special Publication No. 1; and Texas Memorial Museum Bulletin No. 4.

Thomas, B. B., Jr., and Richard M. Burnett

1972 A Study of Clay Smoking Pipes Produced at a Nineteenth Century Kiln at Point Pleasant, Ohio. The Conference on Historic Site Archaeology Papers 1971, Vol. 6, Part 1, University of South Carolina. 
Tunne11, Curtis D.

1966 A Description of Enameled Earthenware from an Archaeological Excavation at Mission San Antonio de Valero (The Alamo). State Building Commission Archeological Program, Report No. 2.

Tunne1I, Curtis D., and Richard Ambler

1967 Archeological Excavations at Presidio San Agustine de Ahumada. State Building Commission Archeological Program, Report No. 6.

Tunnel1, Curtis D., and W. W. Newcomb, Jr.

1969 A Lipan Apache Mission, San Lorenzo de la Santa Cruz, 1762-1771. Texas Memorial Museum Bulletin No. 14 .

Wallace, Ernest and David M. Vigness (Editors)

1962 Documents of Texas History. The Steck Company, Austin.

Webb, Walter Prescott et al.

1952 The Handbook of Texas. 2 volumes. The Texas State Historical Association, Austin.

Weems, John Edward

1969 Men Without Countries. Houghton Mifflin, Boston.

1971 Dream of Empire. Simon and Schuster, New York.

Williams, Amelia

1933 A Critical Study of the Siege of the Alamo and the Personnel of its Defenders. Southwestern Historical Quarterly, Vo1. 36: 252-287; 37: 1-44; 79-115; 157-184; 237-312.

Yeoman, R. S.

1967 The Red Book of United States Coins. Witman Publishing Company, Racine, Wisconsin.

Yoakum, Henders on

1855 History of Texas. Redfield, New York. 
Zacatecas Archives

1793 Inventory of 1793. Rol1 4, frame 5435. San Jose Research Library, San Antonio.

Zavala; Adina de

1917 History and Legends of the Alamo and Other Missions in and Around San Antonio. Private printing, San Antonio. 
NEWSPAPERS

The San Antonio Daily Herald

The San Antonio Daily Express

The San Antonio Express

The San Antonio Light
February 2, 1859

September 14, 1871; March 7, 1869

May 21, 1933

May 19, 1939; October 4, 1962;

February 1, 1959

\section{DOCUMENTS CONSULTED}

Alamo Map File, The Alamo Library.

Archdiocesan Accounts, San Antonio Archdiocese, The Alamo Accounts 1872-1874, The Archives, San Antonio Archdiocese.

Bexar Archives.

Charter of the City of San Antonio and Digest of Ordinances of a Genera1 Character, San Antonio, 1873, Sec. 39.9.

Deed Records of Bexar County, Book 7, p. 213.

General Warranty Deed, Filed June 1, 1871; Bexar County Record Book W1, p. 237.

Journal and Minutes of Council, City of San Antonio, Vol. G, July 12, 1886 to October 15, 1888 .

Opinion of the Supreme Court of Texas in the Case of San Antonio vs. John Odin, The November Term, 1855.

Photographic File, The Alamo Library.

Records of the War Department, Office of the Quartermaster General, Consolidated File, The National Archives, Washington, D.C.

Texas Materials in the Calendared Papers at the Notre Dame University, Microfilm Roll No. 1 1831-1862.

Zacatecan Archives, Microfilm at San José Mission, San Antonio. 